\title{
Long-Term effects of Chronic Additions of Nitrogen, Sulfur and Lime on the Growth and Development of a Central Appalachian Forest
}

Alexander J Storm

Follow this and additional works at: https://researchrepository.wvu.edu/etd

\section{Recommended Citation}

Storm, Alexander J, "Long-Term effects of Chronic Additions of Nitrogen, Sulfur and Lime on the Growth and Development of a Central Appalachian Forest" (2018). Graduate Theses, Dissertations, and Problem Reports. 7262.

https://researchrepository.wvu.edu/etd/7262

This Thesis is protected by copyright and/or related rights. It has been brought to you by the The Research Repository @ WVU with permission from the rights-holder(s). You are free to use this Thesis in any way that is permitted by the copyright and related rights legislation that applies to your use. For other uses you must obtain permission from the rights-holder(s) directly, unless additional rights are indicated by a Creative Commons license in the record and/ or on the work itself. This Thesis has been accepted for inclusion in WVU Graduate Theses, Dissertations, and Problem Reports collection by an authorized administrator of The Research Repository @ WVU. For more information, please contact researchrepository@mail.wvu.edu. 
Long-Term effects of Chronic Additions of Nitrogen, Sulfur and Lime on the Growth and Development of a Central Appalachian Forest

\author{
Alexander J. Storm \\ Thesis submitted \\ to the Davis College of Agriculture, Natural Resources, and Design \\ at West Virginia University \\ in partial fulfillment of the requirements for the degree of \\ Masters of Science in \\ Forest Resources Management \\ Jamie Schuler, Ph.D., Chair \\ Mary Beth Adams, Ph.D. \\ Zachariah Fowler, Ph.D.
}

Department of Forestry and Natural Resources

Morgantown, West Virginia

2018

Keywords: nitrogen deposition, acidic deposition, forest growth and development, Forest Vegetation Simulator, FVS

Copyright 2018 Alexander Storm 


\title{
ABSTRACT \\ Long-Term effects of Chronic Additions of Nitrogen, Sulfur and Lime on the Growth and Development of a Central Appalachian Forest
}

\begin{abstract}
Alexander J. Storm
The central Appalachian region has historically received some of the highest levels of nitrogen and sulfur deposition in the eastern United States. Base poor parent material coupled with future increases in more intensive forest management present a scenario of potential base cation depletion and decreased fertility of central Appalachian forest soils. The Fork Mountain Long Term-Soil Productivity (FM LTSP) site was established in 1996 at the Fernow Experimental Forest (FEF) to document the effects of increased nitrogen $(\mathrm{N})$ and sulfur (S) deposition on a young aggrading forest. I utilized data recorded at multiple points in time in this long-term study to characterize the effects of chronic additions of nitrogen, sulfur, and dolomitic lime on the productivity of the overstory trees of the site. I also setup a framework and calibrated a commonly used forest growth model to project of the effects of the treatments on the trees over the next 40 years.

The results of this study show that chronic additions of $\mathrm{N}$ have not increased overall productivity of the site, nor will they increase the productivity in the future. A negative response in species richness to both ambient and experimentally increased rates of $\mathrm{N}$ and $\mathrm{S}$ deposition was observed ( $\mathrm{P}<0.0448$ ), which may be mitigated though the addition of dolomitic lime. Negatively trending species-specific responses to the fertilizer treatments are predicted to cause changes in future species composition, as well as reduced volume production of the negatively affected species. However, the overall productivity of the site may allow species less sensitive to the treatments to utilize the additional growing space in the fertilized areas, resulting in little to no change in the total volume produced on the site. The findings of this study add to the larger body of work dedicated to describing the effects of chronic $\mathrm{N}$ and $\mathrm{S}$ additions to central Appalachian forests.
\end{abstract}


For my late mother...

Your dedication to my academic success will never be overlooked or forgotten. 


\section{Acknowledgements}

I would like to sincerely thank my major advisor, Dr. Jamie Schuler, for his help and guidance in not only achieving my degree, but also in my professional career. His dedication and commitment to his students serves as a great example for anyone in academia to strive towards. I would also like to thank my co-advisor, Dr. Mary Beth Adams for her expertise and welcoming spirit upon my arrival at the Fernow. It was truly an honor to have the opportunity to work with and get to know her. My third committee, Dr. Zachariah Fowler, also deserves my thanks for not only agreeing to take part in this project, but also for providing me with data and valuable insights in the interpretation of the results from this project.

John Juracko and Brian Simpson from the USFS deserve recognition as the best field crew imaginable. Thanks also go out to my lab mate Breanne Held, for taking time from her schedule to help collect data. I would also like to thank Dr. Ida Holaskova, for her help and

guidance in developing the statistical models used in this study. Also, thanks to the Appalachian Vegetation Management Association and Dr. Kenneth Carvell for additional financial support during my time here at WVU.

Finally, the sincerest of thanks go out to the individuals who have molded me into the professional I am today. To Dr. Beth Brantley and Mr. Craig Houghton, simply put, I would not be in the position I am today without you, and for that you two deserve my undying gratitude. 


\section{Table of Contents}

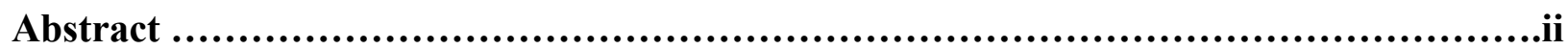

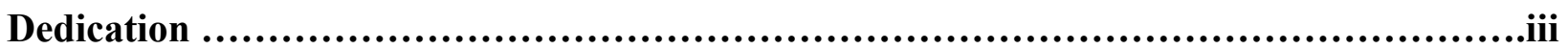

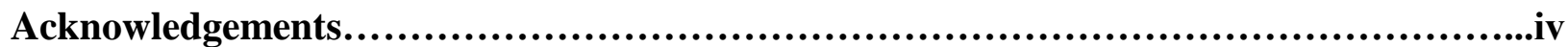

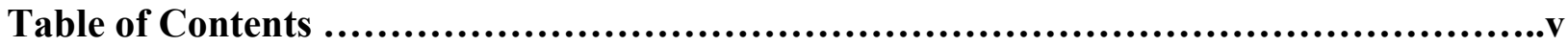

List of Figures.................................................................................

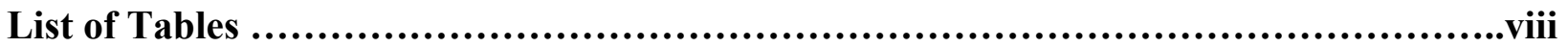

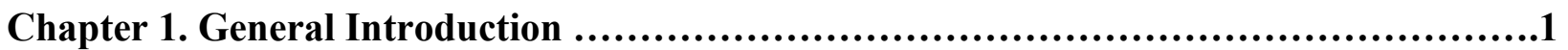

Chapter 2. Effects of 21 years of increased nitrogen and sulfur on stand growth and species composition in an aggrading Appalachian hardwood forest. .....................................5

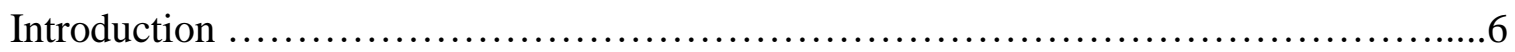

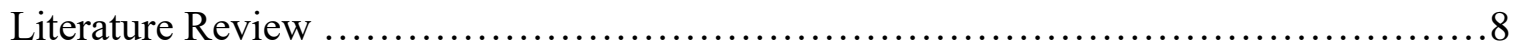

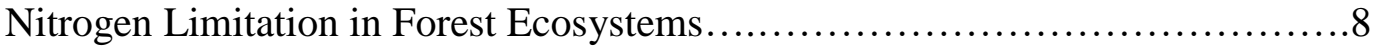

Nitrogen Saturation in Forest Ecosystems .................................. 8

Effects of Chronic Nitrogen and Sulfur inputs on Forest Heath and Growth......11

Fork Mountain LTSP Background ..........................................12

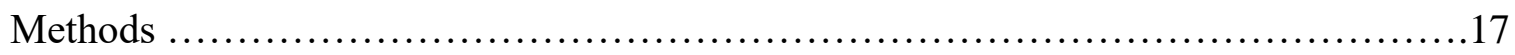

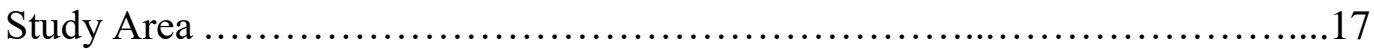

Treatment Description ................................................ 18

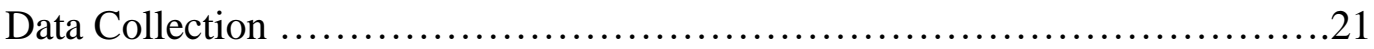

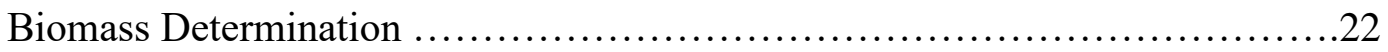

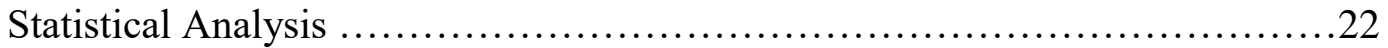

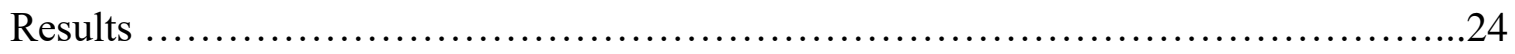

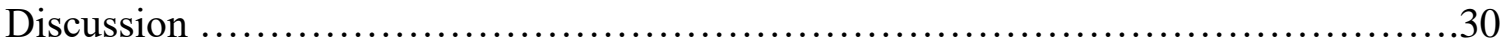

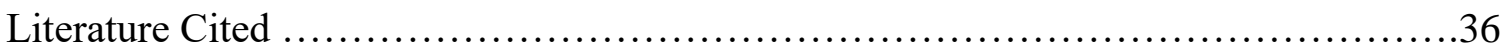


Chapter 3. Use of a locally calibrated and validated forest growth model to project 40 years of species specific responses to chronic additions of nitrogen, sulfur and lime ...............42

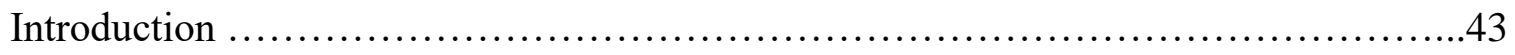

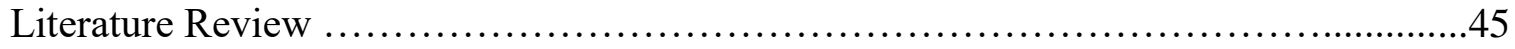

Review of Forest Growth and Successional Models .........................45

Use of the Forest Vegetation Simulator for Forest Growth Projections .............48

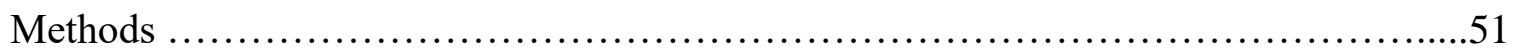

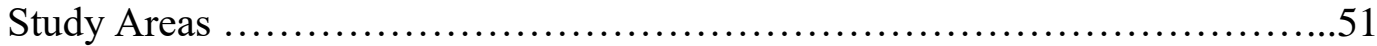

LTSP Treatment Description ......................................54

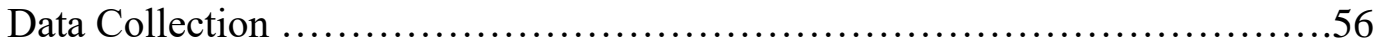

Model Calibration ....................................................57

Model Validation ......................................................61

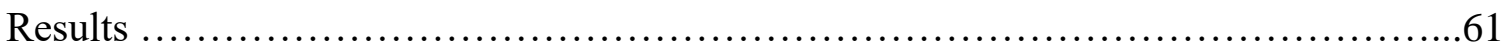

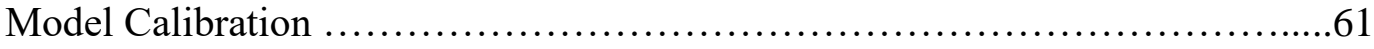

Model Validation ...................................................63

Projection of LTSP Data ............................................65

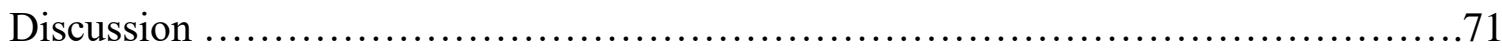

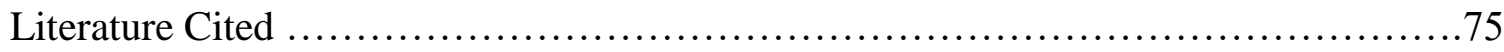

Appendix A. Base model performance vs actual growth of calibration stands .........82

Appendix B. Calibrated Model performance vs. actual growth of calibration stands ....86

Chapter 4: General Conclusions on the long-term effects of chronic additions of nitrogen, sulfur and lime to a central Appalachian forest .......................................90 


\section{List of Figures}

\section{Chapter 2.}

Figure 1. Photo of entrance to Fork Mountain LTSP site representing an example of wind throw

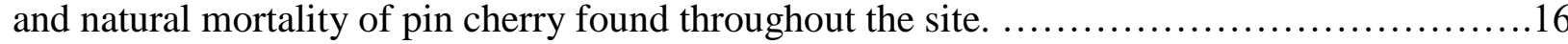

Figure 2. Location map for the Fernow Experimental Forest and Fork Mountain Long-Term Soil Productivity site in Tucker County, WV . ...............................................18

Figure 3. Physical layout of treatments of the Fork Mountain LTSP site. Figure modified from Adams et al., 2004.

Figure 4. Layout of treatment plots of Fork Mountain LTSP. Permanent growth plots are indicated by X's as well as an example of the nested overstory plots. Figure modified from Adams et al., 2004.

Figure 5. Average species richness of measured plots on the Fernow LTSP site $(\mathrm{F}=3.2815, \mathrm{P}=$ 0.0448). Error bars represent 1 standard error of the mean. Columns with different letters are different at $\mathrm{p}=0.05$.

Figure 6. Aboveground woody biomass ( $>1$ ") per acre for the six species with highest RIV on site. Species by treatment interaction $(\mathrm{F}=1.2233, \mathrm{P}=0.2991)$. Error bars represent 1 standard error of the

mean. .26

Figure 7. A) Total aboveground woody biomass (tons/ac) by treatment for all trees measured (F $=0.7605, \mathrm{P}=0.4721)$, and $\mathrm{B})$ for the six species with highest $\mathrm{RIV}$ values $(\mathrm{F}=0.4215, \mathrm{P}=$

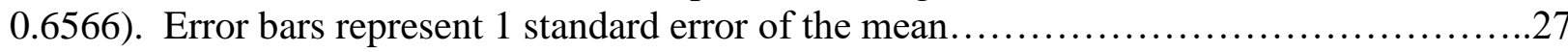

Figure 8. Trees per acre of the six species with highest RIV on site. Species by treatment interaction $(\mathrm{F}=1.0691, \mathrm{P}=0.4027)$. Error bars represent 1 standard error of the mean.........28

Figure 9. Quadratic mean diameter of the six species with highest RIV on site. Species by treatment interaction $(\mathrm{F}=0.8771, \mathrm{P}=0.5554)$. Error bars represent 1 standard error of the mean

Figure 10. Change in treatment effect on aboveground biomass accumulation (tons/ac) over the last 11 years $(\mathrm{F}=0.17, \mathrm{P}=0.9533)$ Error bars represent 1 standard error of the mean.........30

\section{Chapter 3.}

Figure 1. Map of calibration plots and LTSP plot locations within the Fernow Experimental Forest just outside Parsons in Tucker County, West Virginia .............................52

Figure 2. Physical layout of treatments of the Fork Mountain LTSP site. Figure modified from Adams et al., 2004. 
Figure 3. Layout of treatment plots of Fork Mountain LTSP. Permanent growth plots are indicated by X's as well as an example of the nested overstory plots. Figure modified from Adams et al., 2004.................................................................. 55

Figure 4. Workflow for calibration and validation of the northeast variant of the Forest Vegetation Simulator for the Fernow Experimental Forest.

Figure 5. Base FVS Model performance plotted against actual growth data for calibration Stand 32. Model bias is consistent across all calibration stands. The remaining 8 calibration stand graphs of base model performance are included in Appendix A. ........................61

Figure 6. Locally Calibrated FVS Model performance plotted against actual growth data for calibration Stand 32. A visual representation of an example of the decrease in model systematic error after model calibration to local growing conditions (Compare to Figure 5). For visual representation of model performance of the other 8 stands see Appendix B. ...............63

Figure 7. Model projections for increase in average merchantable cubic feet per acre of all species and treatments over time.

Figure 8. Species specific growth predictions for 3 treatments on the LTSP site. Six species (in order of highest - lowest RIV at year 2017) (Table 1 in Chapter 1) are presented and correspond to figures as follows: A) pin cherry, B) yellow-poplar, C) sweet birch, D) black cherry, E) red maple, F) cucumbertree.

\section{Chapter 3. Appendix A:}

Figure 1. Base FVS Model Performance plotted against actual growth data for calibration Stand 33.

Figure 2. Base FVS Model Performance plotted against actual growth data for calibration Stand 34.

Figure 3. Base FVS Model Performance plotted against actual growth data for calibration Stand 35 .

Figure 4. Base FVS Model Performance plotted against actual growth data for calibration Stand 36.

Figure 5. Base FVS Model Performance plotted against actual growth data for calibration Stand 37.

Figure 6. Base FVS Model Performance plotted against actual growth data for calibration Stand 38.

Figure 7. Base FVS Model Performance plotted against actual growth data for calibration Stand 39.

Figure 8. Base FVS Model Performance plotted against actual growth data for calibration Stand 43. 


\section{Chapter 3: Appendix B:}

Figure 1. Locally Calibrated FVS Model performance plotted against actual growth data for

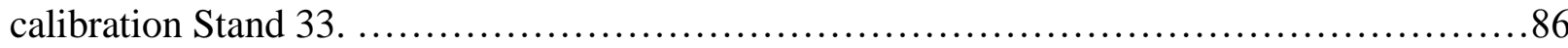

Figure 2. Locally Calibrated FVS Model performance plotted against actual growth data for

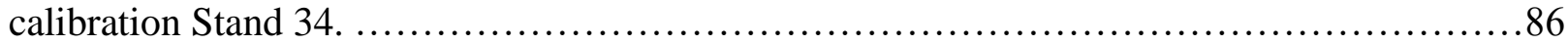

Figure 3. Locally Calibrated FVS Model performance plotted against actual growth data for

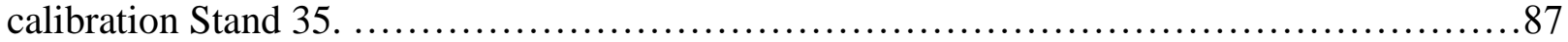

Figure 4. Locally Calibrated FVS Model performance plotted against actual growth data for calibration Stand 36.

Figure 5. Locally Calibrated FVS Model performance plotted against actual growth data for calibration Stand 37.

Figure 6. Locally Calibrated FVS Model performance plotted against actual growth data for

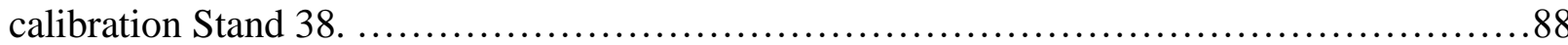

Figure 7. Locally Calibrated FVS Model performance plotted against actual growth data for calibration Stand 39.

Figure 8. Locally Calibrated FVS Model performance plotted against actual growth data for calibration Stand 43. 


\section{List of Tables}

\section{Chapter 2.}

Table 1. Relative Importance Values of all species sampled in all treatment areas in 2017 and 2009. RIV values for 2009 are from Fowler et al., (2014).

Table 2. Seedlings per acre (for six current species of highest RIV) measured in regeneration survey of all 20 permanent rods within each treatment plot in 1997. Asterisk (*) designates significant difference at $\mathrm{P}=0.05$.

\section{Chapter 3.}

Table 1. Description of site features associated with the 18 calibration plots used for model calibration.

Table 2. Species growing at higher rates in calibration plots than what is normally predicted by FVS NE. Species multiplier values here were used to modify the large tree basal area growth function. Species codes are as follows: RM (red maple), SB (sweet birch), YP (yellow-poplar), BC (black cherry), CO (chestnut oak), RL (red elm).

Table 3. Mean percent error (MPE) and Root Mean Square Error (RMSE) values for trees per acre and basal area per acre $\left(\mathrm{ft}^{2} \mathrm{ba} / \mathrm{ac}\right)$ calculated by comparing FVS NE base model and FEF locally calibrated model predictions to observed values in nine calibration stands. Positive numbers represent an overestimation by the model and negative numbers represent underestimation.

Table 4. FVS NE predicted stocking of mean percentage of total trees per acre in each treatment area for 10 year projection intervals. Values of $0 \%$ represent less than $1 \%$ total trees per acre while dashes (-) represent species absence from the corresponding area.

Table 5. Trees per acre for each species and diameter class for the Fork Mountain LTSP in year 2017. 
Chapter 1. General Introduction 
The northeastern United States has historically dealt with severe levels of anthropogenically induced acidic deposition. High concentrations of coal fired power plants in the Ohio River Valley caused elevated rates of nitrogen and sulfur to be released to the atmosphere, resulting in the precipitation of sulfuric and nitric acids across the region. Early detection of acidic deposition in this region (Likens et al., 1972) led to an effort to study the effects of acidic deposition on forests (Johnson, 1983; Ulrich, 1982). In addition to studying the effects of ambient rates of deposition, several research sites were implemented to investigate the response of forest ecosystems to future increases of atmospheric deposition of $\mathrm{N}$ and $\mathrm{S}$ (Aber et al., 1989; Adams et al., 2006; Norton \& Fernandez, 1999; Pregitzer et al., 2004).

The Clean Air Act of 1970 and the CAA Amendments (1977, 1990), were implemented to control the emissions of sulfur oxides $\left(\mathrm{SO}_{\mathrm{x}}\right)$ and nitrous oxides $\left(\mathrm{NO}_{\mathrm{x}}\right)$ from electric power plants. The success of the legislation in reducing atmospheric deposition of $\mathrm{S}$ and stabilizing levels of $\mathrm{N}$ has been substantial (Baumgardner et al., 2002). However, areas of eastern Ohio, northern West Virginia, and western Pennsylvania were still receiving high levels of sulfur deposition up until the mid-1990's (Driscoll et al., 2001). The emissions of $\mathrm{NO}_{\mathrm{x}}$ from the internal engine combustion of fuel has been regulated to a lesser degree and are predicted to continue to contribute to the atmospheric deposition of $\mathrm{N}$ in forests in the future.

Continued elevated deposition of nitrogen in forest ecosystems can result in $\mathrm{N}$ levels greater than what can be used by the biota of a system. Symptoms of this process, known as nitrogen saturation, have been found in central Appalachian forests under ambient rates of $\mathrm{N}$ deposition (Adams et al., 1997; Gilliam et al., 1996; Peterjohn et al., 1996). Central Appalachian forest soils were hypothesized to be sensitive to base cation depletion from nitrogen saturation 
and intensive forest management (Adams et al., 2000). Due to the uncertainty in future reductions in $\mathrm{N}$ deposition rates, concerns were raised about the future productivity of forests in the region. In 1996 the Fork Mountain Long-Term Soil Productivity (FM LTSP) site was established to characterize the long-term effects of elevated rates of nitrogen and sulfur inputs on central Appalachian forests (Adams et al., 2004). In addition, a dolomitic lime treatment was implemented as an attempt to mitigate base cation depletion.

Long-term goals of the FM LTSP study included: 1) documenting the pre-treatment characteristics of forests sensitive to base cation depletion, 2) continually monitor and describe the response of the forest community to the treatments, and 3) develop/improve models to better simulate the response of forest ecosystems to base cation depletion, nitrogen and sulfur deposition, and additions of dolomitic lime (Adams et al., 2004). In this study I have contributed to two of these broad study goals. I characterized the aboveground response of the trees exposed to 21 years of elevated rates of nitrogen, sulfur and lime additions. In addition, I calibrated a commonly used forest growth model to local growth parameters to better simulate the effects of the treatments over the next 40 years. 
Literature Cited:

Aber, J. D., Nadelhoffer, K. J., Steudler, P., \& Melillo, J. M. (1989). Nitrogen Saturation in Northern Forest Ecosystems. BioScience, 39(6), 378-386.

Adams, M. B., Angrandi, T. R., \& Kochenderfer. (1997). Stream water and soil solution responses to 5 years nitrogen and sulfur at the Fernow Experimental Forest, West Virginia. Forest Ecology and Management, 95(96), 79-91.

Adams, M. B., Burger, J. A., Jenkins, A. B., \& Zelazny, L. (2000). Impact of harvesting and atmospheric pollution on nutrient depletion of eastern US hardwood forests. Forest Ecology and Management, 138(1-3), 301-319.

Adams, M. B., Burger, J., Zelazny, L., \& Baumgras, J. (2004). Description of the Fork Mountain Long-Term Soil Productivity Study: Site characterization, 43.

Adams, M. B., DeWalle, D. R., \& Hom, J. L. (2006). The Fernow Watershed Acidification Study. Springer.

Baumgardner, R. E., Lavery, T. F., Rogers, C. M., \& Isil, S. S. (2002). Estimates of the atmospheric deposition of sulfur and nitrogen species: Clean Air Status and Trends Network, 1990-2000. Environmental Science and Technology, 36(12), 2614-2629.

Driscoll, C. T. ., Lawrence, G. B. ., Bulger, A. J. ., Butler, T. J. ., Cronan, C. S. ., Eagar, C. ., ... Weathers, K. C. . (2001). Acidic deposition in the northeastern United States: Sources and inputs, ecosystem effects, and management strategies. BioScience, 51(3), 180-198.

Gilliam, F. S., Adams, M. B., \& Yurish, B. M. (1996). Ecosystem nutrient responces to chronic nitrogen inputs at Fernow Experimental Forest, West Virginia. Canadian Journal of Forest Research, 26, 196-205.

Johnson, A. H. (1983). Red spruce decline in the northeastern u.s.: hypotheses regarding the role of acid rain. Journal of the Air Pollution Control Association, 33(11), 1049-1054.

Likens, G. E., Bormann, F. H., \& Johnson, N. M. (1972). Acid rain. Environment, 14, 33-40.

Norton, S. A., \& Fernandez, I. J. (1999). The Bear Brook Watershed in Maine: a paired watershed experiment: the first decade (1987-1997) (Vol.55). Springer Science \& Business Media.

Peterjohn, W. T., Adams, M. B., \& Gilliam, F. S. (1996). Symptoms of Nitrogen Saturation in Two Central Appalachian Hardwood Forest Ecosystems. Biogeochemistry, 35(3), 507-522.

Pregitzer, K. S., Zak, D. R., Burton, A. J., Ashby, J. A., \& Macdonald, N. W. (2004). Chronic nitrate additions dramatically increase the export of carbon and nitrogen from northern hardwood ecosystems. Biogeochemistry, 68(2), 179-197.

Ulrich, B. (1982). Dangers for the Forest Ecosystem Due to Acid Precipitation. Necessary Countermeasures: Soil Liming and Exhaust Purification. U.S. EPA Translation TR-820011; EPA/NCSU Acid Deposition Program; North Carolina State University, Raleigh. 
Chapter 2. Effects of 21 Years of Increased Nitrogen and Sulfur on Stand Growth and Species Composition in an Aggrading Appalachian Hardwood Forest. 


\section{Introduction}

The forests of the central Appalachian Mountains are both beautiful and productive. The state of West Virginia boasts over 12 million acres of forest cover, accounting for $79 \%$ of the land cover in the state (Morin, 2016). The health of this resource not only influences the social and economic growth of the state, but also the quality of living for its inhabitants (both human and non-human). There is an ongoing need to increase our understanding of the biotic and abiotic stressors influencing the health of our forests.

Historically the burning of fossil fuels, mostly from coal fired power plants in the Ohio River Valley, caused elevated concentrations of nitrogen and sulfur in the atmosphere. Due to a high affinity for water, nitrogen and sulfur have a relatively short mean residence time in the atmosphere, causing deposition of acid rain across the mid-Atlantic and northeastern United States. The precipitation of sulfuric acid $\left(\mathrm{H}_{2} \mathrm{SO}_{4}\right)$ and nitric acid $\left(\mathrm{HNO}_{3}\right)$, are the most common forms of acid rain in the eastern United States (Galloway et al., 1976). Atmospheric deposition of sulfate $\left(\mathrm{SO}_{4}{ }^{2-}\right)$ has historically been extremely high in the central Appalachian region (Driscoll et al., 2001). This garnered region wide concern over the effects of chronic inputs to forested systems.

$\mathrm{H}_{2} \mathrm{SO}_{4}$ and $\mathrm{HNO}_{3}$ in forest soils dissociate and increase the number of hydrogen ions $\left(\mathrm{H}^{+}\right)$ present in soil solution, which can directly change the soil $\mathrm{pH}$ to become more acidic. In addition, $\mathrm{H}^{+}$ions have a high affinity for cation exchange sites in soil, displacing essential plant nutrients to be leached away or to react with other soil nutrients, which then often become locked in forms unavailable to the plant. The forest soils of the central Appalachian Mountains are buffered primarily by the cation exchange capacity of each soil type. In comparison to soils 
buffered by $\mathrm{Ca}^{2+}$ and $\mathrm{Al}^{3+}$ the capacity of cation exchange buffered soils is finite and can be ultimately diminished with continued acidic inputs (Spiro \& Stigliani, 2003). This process is limited by the number of exchange sites that are occupied by $\mathrm{K}^{+}, \mathrm{Na}^{+}, \mathrm{NH} 4^{+}, \mathrm{Ca}^{++}, \mathrm{Mg}^{++}$ cations. The displacement of these cations by $\mathrm{H}^{+}$followed by subsequent leaching can lead to the depletion of cations essential to plant health (Driscoll et al., 2001; Fernandez et al., 2003). When the buffering capacity of these soils is reached, soil pH can be reduced significantly (Spiro \& Stigliani, 2003).

Due to the success of the Clean Air Act (1970) and its amendments (1977, 1990), S deposition has been reduced substantially and $\mathrm{N}$ deposition rates have stabilized in the northeastern US (Baumgardner et al., 2002). Current research focus has shifted to understanding the effects of continued $\mathrm{N}$ deposition on forests. The process of nitrogen saturation occurs as the inputs of the system from decomposition, nitrogen fixation, and atmospheric deposition exceed the capacity of the system to uptake nitrogen (Aber et al., 1989). This excess nitrogen can lower soil pH (Van Breemen et al., 1982), reduce base cation uptake by mobilization of $\mathrm{Al}^{3+}$ (Cronan \& Grigal, 1995; Richter et al., 1991), increase the release of greenhouse gas emissions in soils (Steudler et al., 1989) and increase nitrate leaching into stream-water (Fenn et al., 1998; Peterjohn et al., 1996).

Although the process of nitrogen saturation in forests has been studied for decades (Aber et al., 1989), the effects are highly variable depending on location, ambient levels of nitrogen input, the age of the forest, and the species composition of the overstory species. This study was designed to characterize the overall influence of 21 years of increased nitrogen and sulfur inputs on the growth of a young central Appalachian forest. I was particularly interested in determining the species-specific responses to the treatment for the most prevalent species on the site. I 
hypothesized that the response to the treatments will be species specific, with both positive and negative responses to chronic additions of $\mathrm{N}$ and $\mathrm{S}$.

\section{Literature Review}

\section{Nitrogen Limitation in Forest Ecosystems}

Most temperate forest systems have traditionally been thought of as limited by the amount nitrogen that is available for tree growth (Aber et al., 1989). This generalization is due in part to the response of many forest species to experimental increases in available nitrogen. Nitrogen fertilizer in a one-time application or "pulse" has shown to increase growth of young (Auchmoody, 1982; Newton, Robison, Hansen, \& Allen, 2002) and mature (Auchmoody \& Smith, 1977; Stanturf, 1989) hardwood species. Fertilizers are routinely used in high intensity conifer plantations to supplement soil deficiencies and increase production (Jokela et al., 1991; Jokela et al., 2000; McKeand et al., 2006; Pritchett \& Wells, 1978). These pulse treatments lead to initial increases in growth, ultimately diminishing over time as nitrogen again becomes limited to growth (Fox et al., 2007; Jokela et al., 2000).

Forest disturbances result in short-lived increases of bioavailable nitrogen that exceed biotic demand. As the biota begin to increase in abundance and size, the supply of $\mathrm{N}$ in soils reaches an inflection point (at the time of canopy closure), after which available nitrogen limits or co-limits (generally with phosphorus) the growth of trees (Allen et al., 1990; Fox et al., 2007). Major sources of nitrogen in forests are limited to the mineralization of organic material, fixation of atmospheric nitrogen by bacteria and the deposition of nitrogen from the atmosphere (Schlesinger \& Bernhardt, 2013). Potential growth of forests that do not receive increased N from anthropogenic activities (fertilizer, increased atmospheric deposition) is limited by nutrient 
availability for a large portion of their life cycle (Allen et al., 1990). Increases in N availability from continued elevated rates of atmospheric deposition can lead to an excess of nitrogen in the system (Peterjohn et al., 1996).

\section{Nitrogen Saturation in Forests Ecosystems}

The signs of nitrogen saturation can be observed in soils, plants, and the stream water chemistry of areas receiving chronic $\mathrm{N}$ additions. Symptoms of $\mathrm{N}$ saturation include: sustained increases in nitrogen content in foliage, decreased fine root and mycorrhizal biomass, increased nitrification rates and thus increased nitrous oxide emissions from soils, increased leaching of nitrate from soils, and forest decline in conifers (Aber et al., 1989). Increased nitrogen deposition is a global issue, having influence on forests in Europe (Van Breemen et al., 1982), Asia (Galloway et al., 2004), as well as the eastern United States.

Sustained increased inputs of nitrogen to a forests have been shown to increase foliar nitrogen concentrations in many regions of the United States (Boggs et al., 2005; Elvir et al., 2005; Gilliam et al., 1996; Magill et al., 2004; Pregitzer et al., 2008). Increased foliar N is thought to increase photosynthetic activity (and subsequently growth) in fertilized trees due to its critical role as a major component of chlorophyll. However, there has not been evidence suggesting increased photosynthesis following chronic nitrogen additions for conifers (Bauer et al., 2004; Schaberg et al., 1997). Talhelm et al. (2011) found no evidence of increased photosynthesis in sugar maple (Acer saccharum) trees exposed to chronic additions of $\mathrm{NO}_{3}{ }^{-}$in Michigan.

One historical hotspot of nitrogen deposition has been the central Appachian region. Signs of experimentally induced nitrogen saturation have been observed in stream water in this 
region. In a young, aggrading forest in $\mathrm{WV}$, a rapid increase in nitrate dishcharge from a fertilized watershed was measured just one year after of the initiation of elevated nitrogen deposition treatments (Peterjohn et al., 1996). When compared to a control watershed, the fertilized watershed has signifigantly lower stream water $\mathrm{pH}$ values (Edwards et al., 2006). This continually fertilized area has sustained elevated rates of $\mathrm{NO}_{3}{ }^{-}$leaching for over two decades (Gilliam et al., 2018). It has traditionaly been thought that a young, fast growing forest would have the capacity to utilize added inorganic nitrogen by increasing growth (Peterjohn et al., 1996). However, if background $\mathrm{N}$ additions were already at or near the point of $\mathrm{N}$ saturation, the trees would be limited in growth by other essential nutrients and would not have the capacity to utilize any additional nitrogen (Aber et al., 1989).

It is important to note that the response to elevated $\mathrm{N}$ in deciduous forests is dynamic, varying both spatially and temporally (Gilliam et al., 2018). A short time after Gilliam (1996) reported fertilized trees trending toward having higher foliar $\mathrm{N}$ concentrations compared to nonfertilized trees, statistically lower foliar nitrogen concentrations were found in fertilized trees in the same area (May et al., 2005). Athough higher foliar N concentrations are thought of as a symptom of $\mathrm{N}$ satuaration, the capacity of a trees to take up additional $\mathrm{N}$ may diminish as availability increases, making detetection of nitrogen saturation using this symptom more complicated (Aber et al. 1991; Vitousek, 1982). Recent work shows that increases in $\mathrm{Al}^{3+}$ in soil can decrease the ability of trees to take up nitrogen in the form of nitrate, leading to increases in nitrate leaching (Burnham et al., 2017). However, nitrogen use efficiency in hardwood forests has been reported to increase in as $\mathrm{N}$ deposition increases (Aber et al., 1998). The complex nature of these interactions highlight the need for the continuation of multiple longterm studies of the effects of increased nitrogen on forests and their associated soils throughout time. 


\section{Effects of Chronic Nitrogen and Sulfur inputs on Forest Health and Growth}

The growth response of trees to increased $\mathrm{N}$ and $\mathrm{S}$ is both species specific, as well as a dynamic response that changes over time and the spatial extent of a species range. Repeated measures of growth after 20 years of nitrate additions in Michigan showed sustained increases in incremental growth and net primary productivity from chronic additions of $\mathrm{NO}_{3}{ }^{-}$(Pregitzer et al., 2008). Chronic additions of high levels nitrogen at the Harvard Research Forest has led to near complete mortality of red pine (Pinus resinosa) and increased stress on trees receiving lower levels of N (Magill et al., 2004). The same study showed increased hardwood net primary productivity in areas receiving high nitrogen additions over a 15 year period. However, increased mortality of red maple (Acer rubrum) in areas with high $\mathrm{N}$ additions after a drought suggests that certain species may have decreased resistance to environmental stress after exposure to chronic $\mathrm{N}$ additions (Magill et al., 2004).

Research at the Fernow Experimental Forest (FEF) near Parsons, WV has documented some of the complex responses of individual overstory tree species to chronic $\mathrm{N}$ additions. Species such as black cherry (Prunus serotina) and yellow-poplar (Liriodendron tulipifera) have been shown to respond positively in terms of biomass production in the early years of stand development to ammonium sulfate fertilizer (Adams et al., 2007). The same study showed no significant difference in growth between fertilized and non-fertilized red maple and sweet birch trees. However, relative growth rates from tree core data showed significant decreases in radial growth rates for yellow poplar, black cherry, and red maple after approximately 9 years of ammonium sulfate additions (DeWalle et al., 2006). A similar response by yellow-poplar was observed in another FEF fertilized stand after 13 years of treatment (Fowler et al., 2015). May et al., (2005) observed a 37\% lower 2 year growth rate for red maple, yellow-poplar and black 
cherry trees exposed to 10 years of chronic $\mathrm{N}$ additions. The differences in response between biomass accumulation and individual incremental growth rates, highlight the possibility of delayed detection of the negative effects of ammonium sulfate additions on aboveground growth.

Elevated rates of nitrogen and sulfur have been correlated with health and vigor problems for many forest species. Increased mortality rates were measured in a hardwood forest that was exposed to 8 years of chronic nitrogen additions (Wallace et al., 2007). Sugar maple, an important species in the central Appalachian forests, has been observed to exhibit substantial dieback in other areas of its range that receive high amounts of acid rain (Houston, 1999). While it is not the only cause of dieback, acidic deposition can alter soil chemistry, increasing available $\mathrm{Al}^{3+}$ which decreases available levels of $\mathrm{Ca}^{2+}, \mathrm{Mg}^{2+}$, and $\mathrm{K}^{+}$, subsequently causing stress to

conifer species (Shortle \& Smith, 1988) as well as hardwood species (Schaberg et al., 2006).

There has been some success in reducing the negative effects acidic deposition on hardwood species through the addition of calcium. Calcium additions have been shown to increase the amount of exchangeable $\mathrm{Ca}$ and $\mathrm{Mg}$ in soils affected by acidic deposition, resulting in increases in sugar maple diameter growth and crown vigor (Huggett et al., 2007; Long et al., 1997). Fowler et al., (2015) measured a significant increase in biomass accumulation of yellowpoplar with the addition of dolomitic lime to trees receiving ammonium sulfate fertilizer.

\section{Fork Mountain LTSP Background}

Between the 1980's and 1990's there was a movement to study the long-term effects of increased nitrogen and sulfur deposition due to the possible widespread negative influences on forests. The Fork Mountain Long-Term Soil Productivity site (LTSP) was established within the FEF in 1996 as a part of a nation-wide effort to quantify anthropogenic influences on forest soil 
long-term productivity. The main goal of the study was to characterize the effects of base cation removal from central Appalachian forest soils by acid deposition and whole tree harvesting methods.

At the time of the study's implementation more intensive harvesting practices, such as whole tree harvesting were becoming popular in the state of West Virginia as a method to increase the biomass extracted from harvest sites. Due to the high nutrient concentrations of hardwood canopies (in comparison to bole wood), the removal of fine branches and foliage results in a large net removal of nutrients from the site that would otherwise not occur using traditional harvesting methods (Vance et al., 2018). Although the extent of negative effects of intensive forest harvesting on nutrient availability has been inconsistent across different ecosystems, soils with a low capacity to provide base cations to the system are at higher risk of nutrient limitation from intensive harvesting (Thiffault et al., 2011).

The soils on the LTSP site are classified as Calvin, Berks and Hazelton series and are derived from sandstone colluvium, sandstone residuum, and weathered shale (Adams et al., 2004). In comparison to soils derived from limestone, the base-poor nature of the parent material on site is highly susceptible to base cation leaching. Thirteen years of ammonium sulfate treatments on site resulted in lowered soil $\mathrm{pH}$ values and increased soil levels of $\mathrm{Al}^{3+}$ (Fowler, 2014).

Prior to harvesting, the overstory (trees greater than 1 in $\mathrm{DBH}$ ) on the site were comprised mostly (in terms of relative importance value) of sugar maple, northern red oak (Quercus rubra), striped maple (Acer pensylvanicum), black cherry, red maple, and yellowpoplar (Adams et al., 2004) . Higher densities of the three maple species and their relatively low basal area (compared to other species) suggests more small maple stems were present than other 
species at that time. Relatively high basal area but lower densities of northern red oak, black cherry and yellow-poplar suggests fewer, larger individual stems of these species.

Regeneration and seedbed potential on the site was also determined prior to treatment initiation. Black cherry seedlings accounted for nearly half the total woody reproduction for commercial tree species with striped maple, yellow-poplar, sugar maple, red maple, northern red oak, and white ash (Fraxinus americana) also being present in significant quantities. Greenbrier (Smilax spp.), and Rubus spp. were the most abundant species of competing vegetation, with densities of approximately 2100 and 1215 stems/ac, respectively. A seedbank germination study showed the seedbed was estimated to supply the stand with over 28000 seedlings per acre of sweet birch and yellow-poplar (Adams et al., 2004), with pin cherry (Prunus pensylvanica) being the next closest species with the potential of just below 12000 seedlings/ac. There was little to no occurrence of viable seeds of oak and maple species identified in this pre-treatment seedbank survey (Adams et al., 2004).

The site, which has now been receiving treatment for 21 years, has until recently been largely dominated by pin cherry which is a common early successional species in the region. Pin cherry, which was not present in the overstory at the time of harvest (Adams et al., 2004), can produce seeds capable of staying viable in the soil for over 75 years (Graber \& Thompson, 1978; Harrington, 1972). The probability of pin cherry seeds staying viable diminishes little in the first 40 years after being produced, but is reduced significantly as the seeds approach 100 years of age (Graber \& Thompson, 1978; Marquis, 1975). Although often referred to as a disturbance dependent germination response, there is evidence suggesting the breaking of seed dormancy in pin cherry is a nitrogen dependent response (Auchmoody, 1979). In areas receiving high amounts of nitrogen deposition that are also under pressure for shorter harvest rotations there is 
potential for increasing pin cherry dominance in early stand development.

The variability in succession of pin cherry in naturally regenerated hardwood stands has been well documented (Hibbs, 1983; Jensen, 1943; Marks, 1974; Wang \& Nyland, 1996, etc.). The longevity of the species in a stand is mostly dependent on the early importance of the species on the site (Nyland et al., 2007). In stands originating with a high densities of pin cherry, the number of pin cherry stems can decrease by $75 \%$ by year 15 , although some live trees can persist up to 40 years in the stand (Ristau \& Horsley, 1999). The same study also found that sites with low initial pin cherry density exhibited the same early decrease in density, however the species was lost from the stand within 30 years of development. Most accounts of pin cherry occurrence show the species disappearing from stands by the $45^{\text {th }}$ year of development (Nyland et al., 2007).

Mortality of pin cherry on the Fork Mountain LTSP site has been substantial in the last 6 years (Figure 1). A windstorm on Christmas day of 2009 caused wind throw, canopy damage and stem bending to overstory trees (Walter, 2016). Damage was primarily concentrated on pin cherry trees but some yellow-poplar, black cherry and sweet birch were also affected by the weather event. In the fall of 2012, another weather event, Superstorm Sandy, deposited large amounts of heavy snow in the area around the FEF in a time of the year when many trees had yet to drop their foliage. The combination of these two events caused damage to approximately $50 \%$ of the stems on site from snow, ice loading and wind throw (Walter, 2016). Walter (2016) also found evidence suggesting trees on fertilized plots have a higher likelihood of being damaged by high winds compared to the trees on non-fertilized plots. 


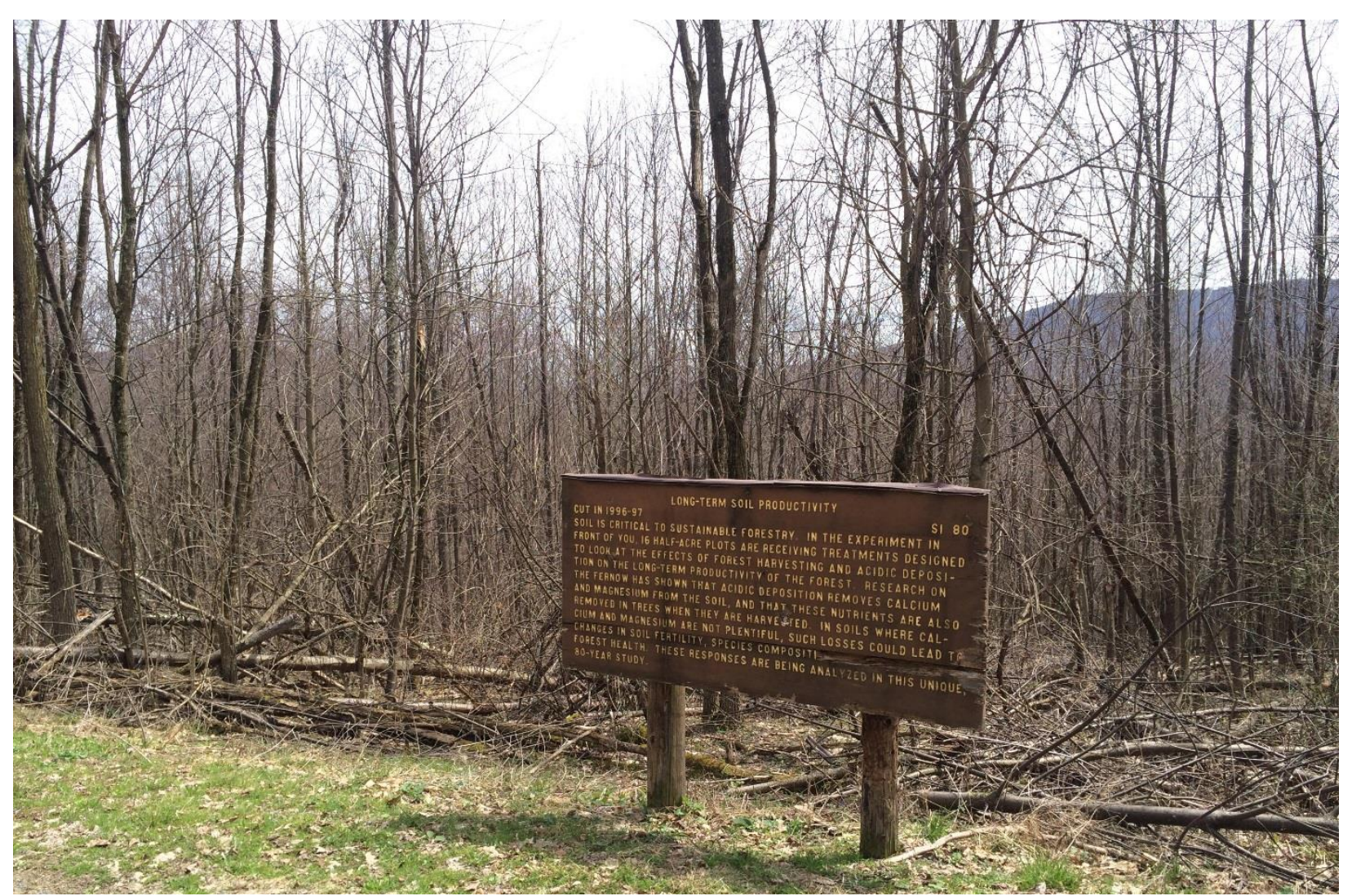

Figure 1. Photo of entrance to Fork Mountain LTSP site representing an example of wind throw and natural mortality of pin cherry found throughout the site.

The density of pin cherry in the early years of development can also influence the overall productivity of the successive stand (Hannah, 1991; Leak, 1988; Marks, 1974; Ristau \& Horsley, 1999). When prevalent in high densities, as at the Fork Mountain LTSP site, pin cherry can slow the development and trigger mortality of more shade tolerant species (Nyland et al., 2007). Slower growing, more shade tolerant species such as sugar maple have been shown to have reduced stem densities and numbers of trees in the dominant crown positions in areas where pin cherry abundance is high (Heitzman \& Nyland, 1994). 


\section{$\underline{\text { Methods }}$}

\section{Study Area}

This study was conducted at the Fork Mountain Long-Term Soil Productivity site on the Fernow Experimental Forest in Tucker County, WV near the town of Parsons (Figure 2). The approximately 4,700 acre forest was established in 1934 as an outdoor laboratory and classroom to conduct research and demonstrate forest practices. The area was heavily logged in the first decade of the $20^{\text {th }}$ century, resulting in a young aggregating forest with some remote, residual, old growth sugar maple trees ( Adams \& Kochenderfer, 2015). While early research was focused primarily on silvicultural and hydrological studies, more current work includes research in soil productivity, species restoration, nutrient cycling, aquatic and wildlife ecology, etc.

The Fork Mountain LTSP site is approximately 30 acres with a predominant southeast aspect and slopes between 15 and 30 percent. The elevation of the site ranges from approximately 2600 to 2800 feet above sea level. At the initiation of the study the average age of the stand was 85 years old, with a site index (base age 50) for red oak of 80 feet, and was classified as a central Appalachian mixed hardwood forest type. 


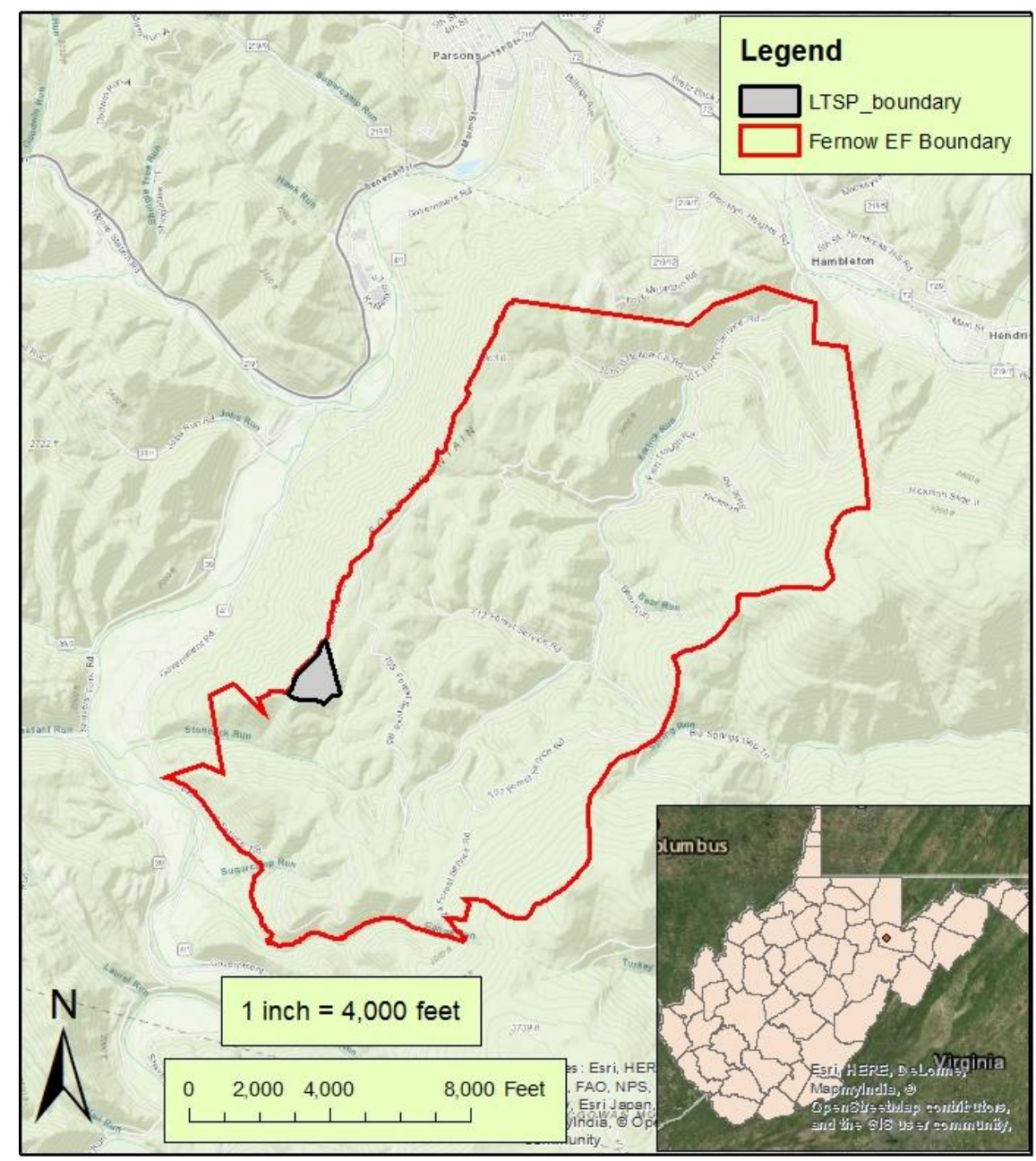

Figure 2. Location map for the Fernow Experimental Forest and Fork Mountain Long-Term Soil Productivity site in Tucker County, WV.

\section{Treatment Description}

To determine the long-term effects of elevated rates of acidic deposition on forest productivity, four treatments were implemented on the site in a complete randomized block design (Figure 3). Each of the four blocks contains one of the treatment plots with blocks being based on slope position. Each treatment block is made up of a 0.5 ac growth plot $(150 \mathrm{ft} \times 150$ ft) and a 25 foot untreated buffer strip which surrounds the growth plot (Figure 4). Within each 
treatment plot a total of 40 permanent rods were installed in a systematic grid to monument the location of permanent subplots.

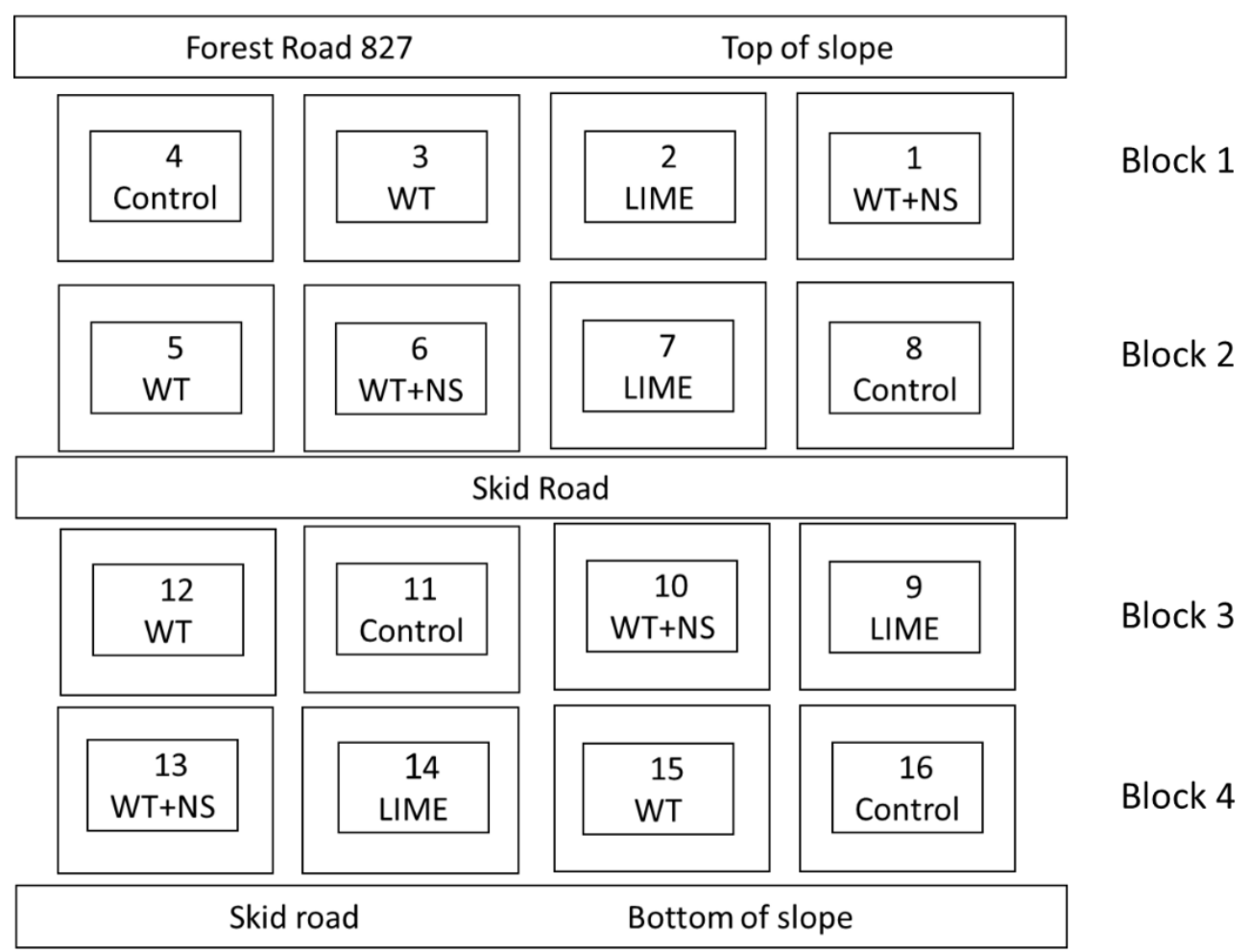

Figure 3. Physical layout of treatments of the Fork Mountain LTSP site. Figure modified from Adams et al., 2004. 
Overstory Plots:

Small Circle $\left(\mathrm{DBH}<5^{\prime \prime}\right)=1 / 100^{\text {th }}$ acre

Large Circle $\left(\mathrm{DBH}>5^{\prime \prime}\right)=1 / 10^{\text {th }}$ acre

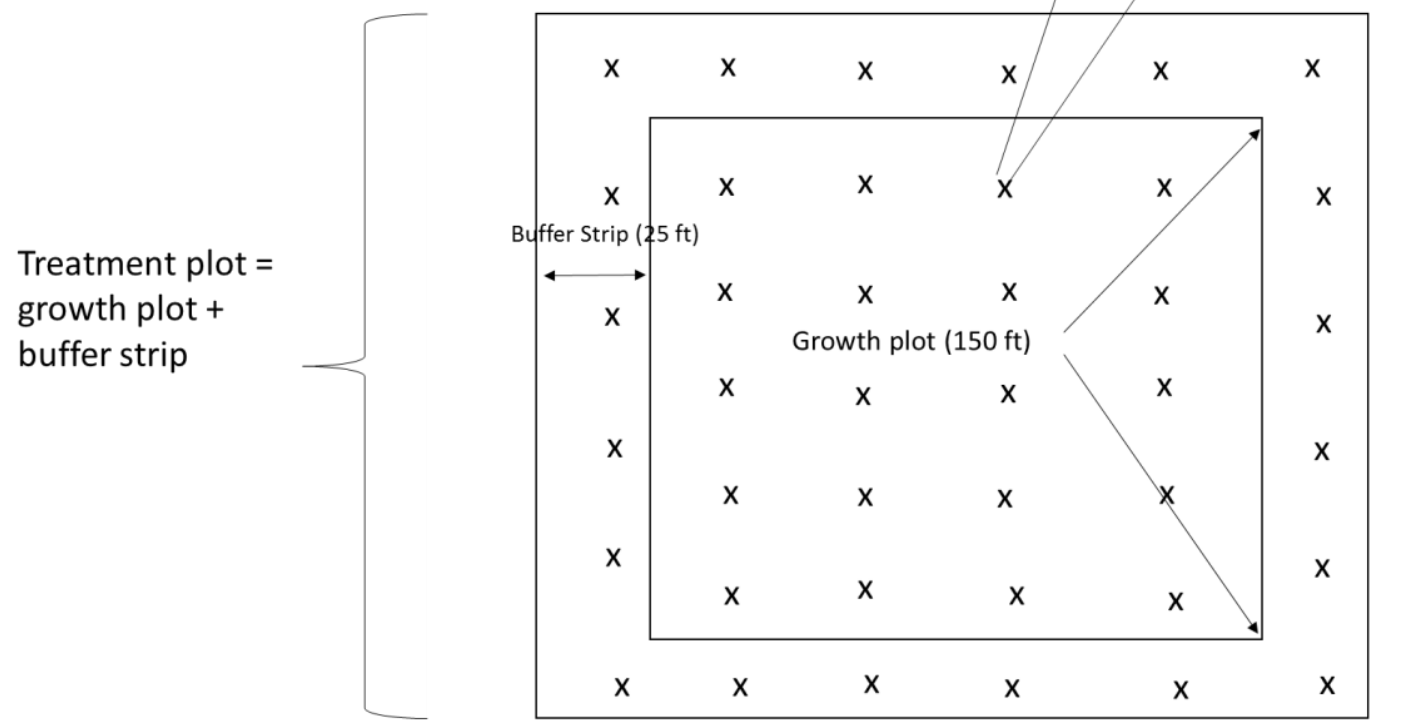

Figure 4. Layout of treatment plots of Fork Mountain LTSP. Permanent growth plots are indicated by X's as well as an example of the nested overstory plots. Figure modified from Adams et al., 2004.

The treatments included uncut control (CTRL), whole tree harvest (WT), whole tree harvest with the addition of ammonium sulfate fertilizer $(\mathrm{WT}+\mathrm{NS})$, and whole tree harvest + ammonium sulfate fertilizer + dolomitic lime addition (LIME). The ammonium sulfate was added at twice the ambient nitrogen (13.4 lbs. N/ac/yr) and sulfur (15.2 lbs. S/ac/yr) throughfall rates measured in the area in 1980-1981 (Helvey \& Kunkle, 1986). The dolomitic lime was added at twice the measured rate of calcium (10.0 lbs. Ca/ac/yr) and magnesium (5.2 lbs. Mg/ac/yr) exported from a nearby watershed in 1993 (Adams et al., 2007). The dolomitic lime addition serves to mitigate the negative effects of soil acidification in order to better understand the effect of continual 
nitrogen addition the ecosystem. Soil additions were applied as split applications three times per year to simulate natural deposition patterns. The CTRL plots were not included in this study due to different successional stage in comparison to the treated plots.

\section{Data Collection}

2017 Data

Due to the perceived changes in stand composition and in order to obtain height data for a sample of dominant and codominant stems, I measured the trees on an additional 60 plots in 2017. Trees between $1-5$ inches DBH were measured on 0.01 acre plots, while trees greater than 5 inches at DBH are measured on a 0.1 acre plot area. This type of inventory allowed us to characterize not only the species composition and density of smaller trees, but also provide a more representative sample of the dominant trees on the site. Species, DBH, quality and crown class were recorded for each tree, and height was measured on select dominant and codominant trees.

\section{Regeneration Data}

Initial number of seedlings per acre data were retrieved from a USFS database at the FEF. On each of the 20 permanent subplots within each treatment area, seedlings were counted by species, height class, and origin. I combined all height classes and origins into 1 count of each species for each subplot.

\section{$\underline{\text { Historical Data for Repeated Measures Analysis }}$}

Trees greater than 1 inch DBH have been periodically sampled every 5 years by USFS personnel since the initiation of the study/treatments. Within each of treatment plot areas (WT, WT+NS and LIME), five 0.01 acre subplots were randomly sampled in each inventory. Trees 
greater than 1 inch DBH were measured on each of the 60 plots and values for species, DBH, origin, quality and crown class were recorded. I had initially planned to use data from two of these inventories (2006 and 2011), but a note recorded on a data sheet for the 2011 inventory led me to believe that data was missing for trees greater than 5 inches on many of the plots.

I was permitted access to a dataset collected in 2009 on the LTSP site as part of a dissertation from former West Virginia University graduate student. This dataset was used in place of the 2011 USFS dataset. Within each treatment plot, six randomly selected 0.02 acre square (25.6 ft. x $34.1 \mathrm{ft}$.) plots were sampled and for all trees greater than 1 inch $\mathrm{DBH}$, the species, DBH and status were recorded (Fowler, 2014).

\section{Biomass Determination}

Generalized allometric biomass equations (Chojnacky et al., 2014) were used to determine the aboveground biomass (trees $>1$ ") on the site. Some species present on the site were not included in the Chojnacky's taxa groupings for the generalized equations: cucumbertree (Magnolia acuminata), American hornbeam (Carpinus caroliniana), devil's walking stick (Aralia spinosa) and mountain holly (Ilex montana). Cucumbertree was included with the other Magnoliaceae species and hornbeam was placed in the Betulaceae $\geq 0.60$ specific gravity group (based on Miles \& Smith, 2009). Due to similar a similar specific gravity value, the equation from the Cornaceae/Ericaceae/Lauraceae/Platanaceae/Rosaceae/Ulmaceae taxa grouping was used to estimate biomass for mountain holly and devil's walking stick, based on the specific gravity of the species (Briand et al., 1999; Miles \& Smith, 2009).

\section{Statistical Analysis}

Relative importance values (RIV) were calculated for each species on the LTSP site to 
describe the composition of the stand (Cottam \& Curtis, 1956). Relative importance value is determined for each species as the sum of the relative density, relative frequency and relative dominance. The maximum value for all species is 300 , and values reported for each species are a percentage of that total. Equations used to calculate relative density, frequency and dominance are as follows:

$$
\begin{gathered}
\text { Relative density }=\frac{\# \text { of individual of the species }}{\# \text { of individal of all the species }} * 100 \\
\text { Relative frequency }=\frac{\# \text { of occurrences of the species }}{\# \text { of occurrence of all the species }} * 100 \\
\text { Relative dominance }=\frac{\text { total basal area of the species }}{\text { total basal area of all species }} * 100
\end{gathered}
$$

Due to the nature of the sampling technique used for the 2017 overstory inventory, individual tree data were expanded to a per acre equivalent, to normalize for the difference in sampling intensity for the small ( $<5$ ”) and large trees ( $\geq 5$ "). Data was analyzed using 2 way ANOVA with SAS JMP, version 13.0 statistical software (JMP) for the 6 most prevalent species. We accounted for the differences in topographic position of the plots by using block as a random effect in the mixed model. Biomass and trees per acre data were transformed using a square root transformation to meet the normality assumptions of ANOVA. P and F values are reported from transformed data, while reported means and figure data are from back-transformed means and standard errors. The Tukey Kramer HSD posteriori test was utilized to determine differences for model effects where p-values were less than 0.05 . I also used a slicing technique in the 2 way ANOVA to interpret the within-species effect of the treatments.

Three independent measurement periods from the site were combined to determine the 
change in aboveground biomass over the last 11 years as affected by the treatments. Due to differences in sampling protocol for the three inventories, all biomass values for individual stems were expanded to a per acre basis and then summed by subplot. Since the same subplots were not measured each period, the analyses were performed on the plot-level averages. The repeated measures ANOVA took into account the irregular spacing of time intervals for the measurements. These datasets were analyzed using SAS 9.4 statistical software (SAS Institute Inc., Cary, NC).

\section{$\underline{\text { Results }}$}

In the last 8 years of growth and development, the species composition of the site has changed little, but the importance of the species present has varied substantially (Table 1). Most notably, the relative importance of pin cherry on the site has decreased. It was the only species with an RIV greater than two percent in 2009 that decreased in importance. Over this period, yellow-poplar increased in RIV the most (8.2\%), followed sweet birch (4.5\%) and cucumbertree (3.6\%). Other notable increases in RIV of species included black cherry (2.5\%) and Frasier magnolia (2.6\%). Three species (Carpinus caroliniana, Tilia americana, Quercus montana) that combined for $<1 \%$ RIV in the 2009 inventory were not found in the 2017 sample. The ingrowth of one eastern hemlock (Tsuga canadensis) tree was the only new species encountered. In addition, there was a difference in the species richness of the treatments areas. The plots receiving the LIME treatment averaged about 1 species per subplot more than the WT+NS and WT treatments $(\mathrm{F}=3.2815, \mathrm{P}=0.0448)$. 
Table 1. Relative Importance Values of all species sampled in all treatment areas in 2017 and 2009. RIV values for 2009 are from Fowler et al., (2014).

\begin{tabular}{lcccc}
\hline Species & Code & RIV 2009 & RIV 2017 & \% Difference \\
\hline Prunus pensylvanica & PRPE & $51.9 \%$ & $28.9 \%$ & $-23.0 \%$ \\
Liriodendron tulipifera & LITU & $12.8 \%$ & $21.0 \%$ & $8.2 \%$ \\
Beula lenta & BELE & $12.4 \%$ & $16.9 \%$ & $4.5 \%$ \\
Prunus serotina & PRSE & $7.5 \%$ & $10.0 \%$ & $2.5 \%$ \\
Acer rubrum & ACRU & $4.2 \%$ & $4.7 \%$ & $0.5 \%$ \\
Magnolia acuminata & MAAC & $1.0 \%$ & $4.6 \%$ & $3.6 \%$ \\
Magnolia fraseri & MAFR & $0.9 \%$ & $3.5 \%$ & $2.6 \%$ \\
Acer pensylvanicum & ACPE & $2.3 \%$ & $2.7 \%$ & $0.4 \%$ \\
Quercus rubra & QURU & $1.6 \%$ & $2.1 \%$ & $0.5 \%$ \\
All other species & - & $5.2 \%$ & $5.7 \%$ & $0.5 \%$ \\
\hline
\end{tabular}

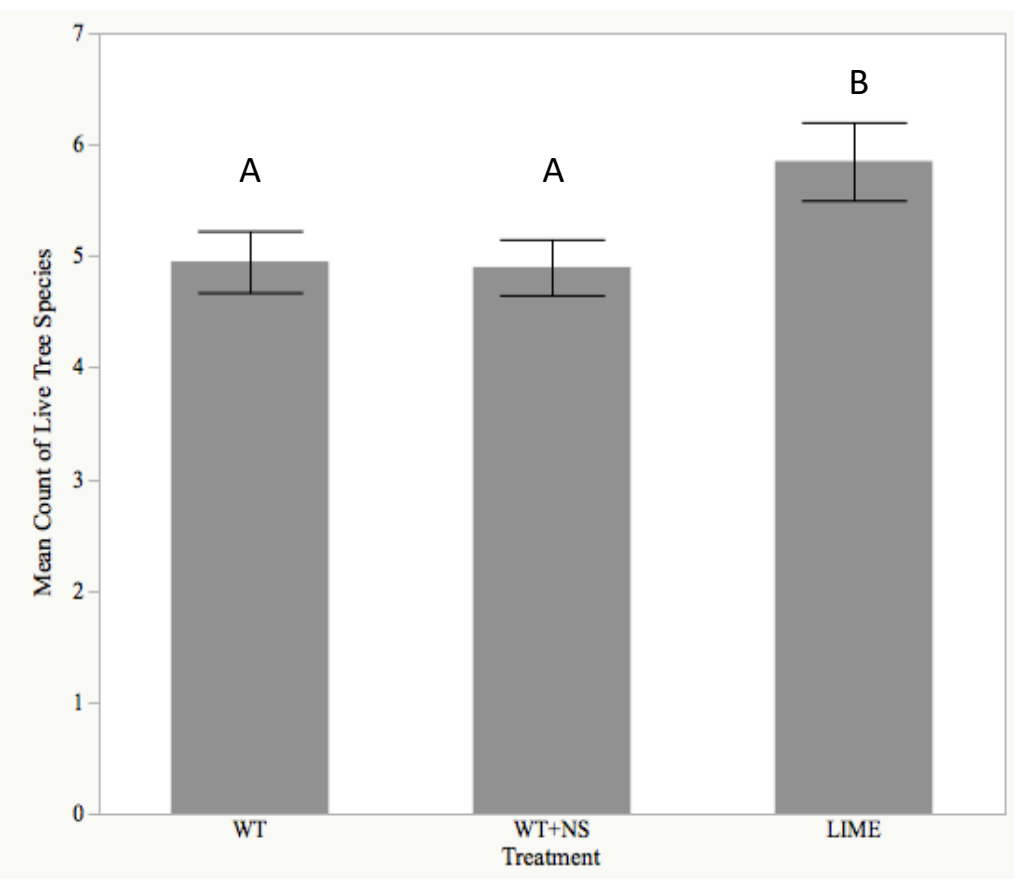

Figure 5. Average species richness of measured plots on the Fernow LTSP site $(\mathrm{F}=3.2815, \mathrm{P}=$ 0.0448). Error bars represent 1 standard error of the mean. Columns with different letters are different at $\mathrm{p}=0.05$. 
The cumulative aboveground growth response to 21 years of treatment of the 6 species with highest RIV values was tested (Figure 6). There was no interaction between the treatments and species $(\mathrm{F}=1.2233, \mathrm{P}=0.2991)$ for aboveground woody biomass production. The main effect of species was significant $(\mathrm{F}=19.4297, \mathrm{P}<0.0001)$, with pin cherry accumulating the greatest biomass in both of the fertilized areas. There was no treatment effect $(\mathrm{F}=0.0137, \mathrm{P}=$ 0.9864) on aboveground biomass production and no significant species responses to any of the treatments were found. There was also no effect of treatment on the total woody biomass when all species were included in the analysis $(\mathrm{F}=0.7605, \mathrm{P}=0.4721)$ (Figure $7 \mathrm{~A})$, or when just the top six species were included $(\mathrm{F}=0.4215, \mathrm{P}=0.6566)$. The top six species on average make up between $90-96 \%$ of the total biomass on site depending on treatment (Figure 7B).

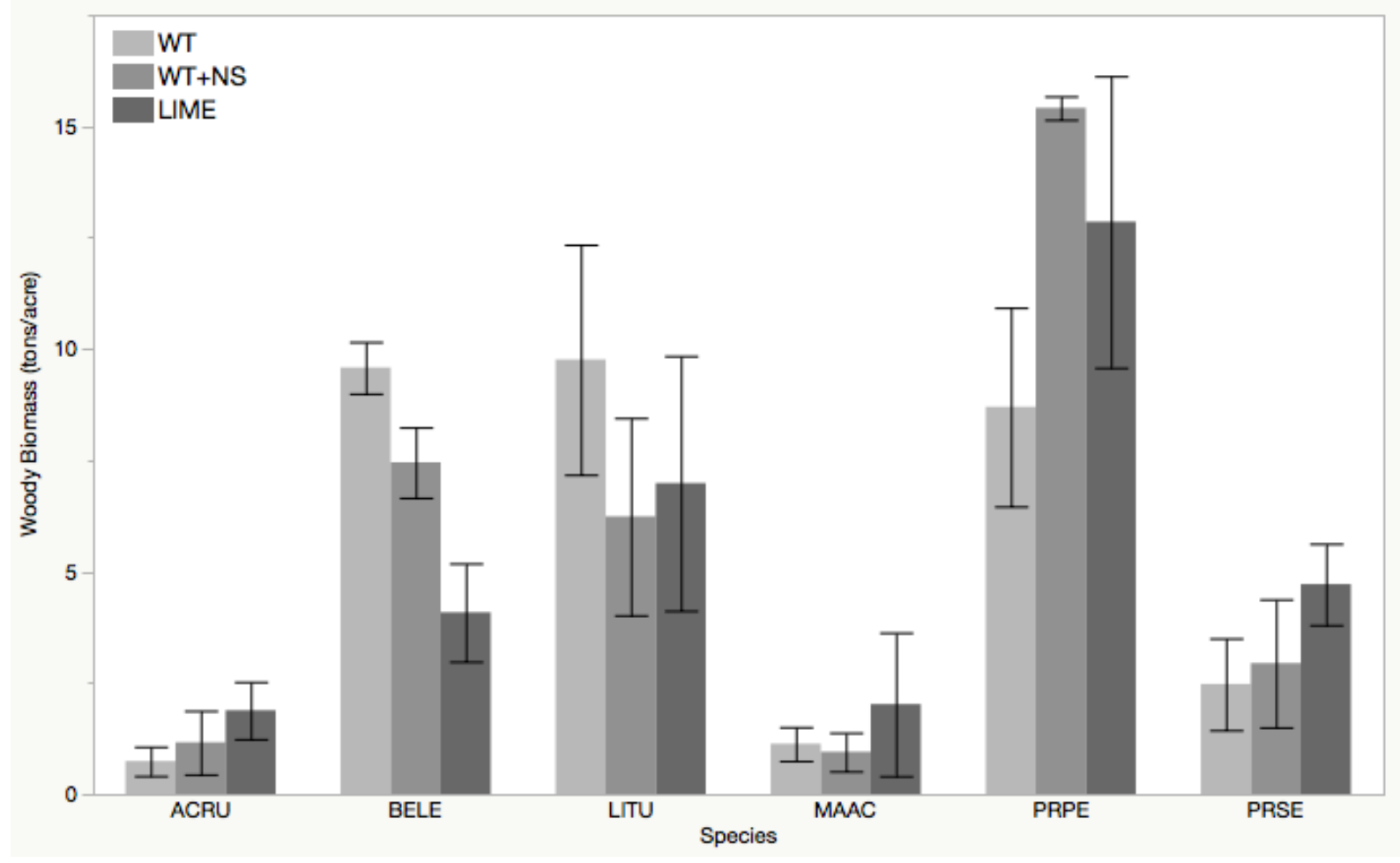

Figure 6. Aboveground woody biomass ( $>1$ ") per acre for the six species with highest RIV on site. Species by treatment interaction $(\mathrm{F}=1.2233, \mathrm{P}=0.2991)$. Error bars represent 1 standard error of the mean. 


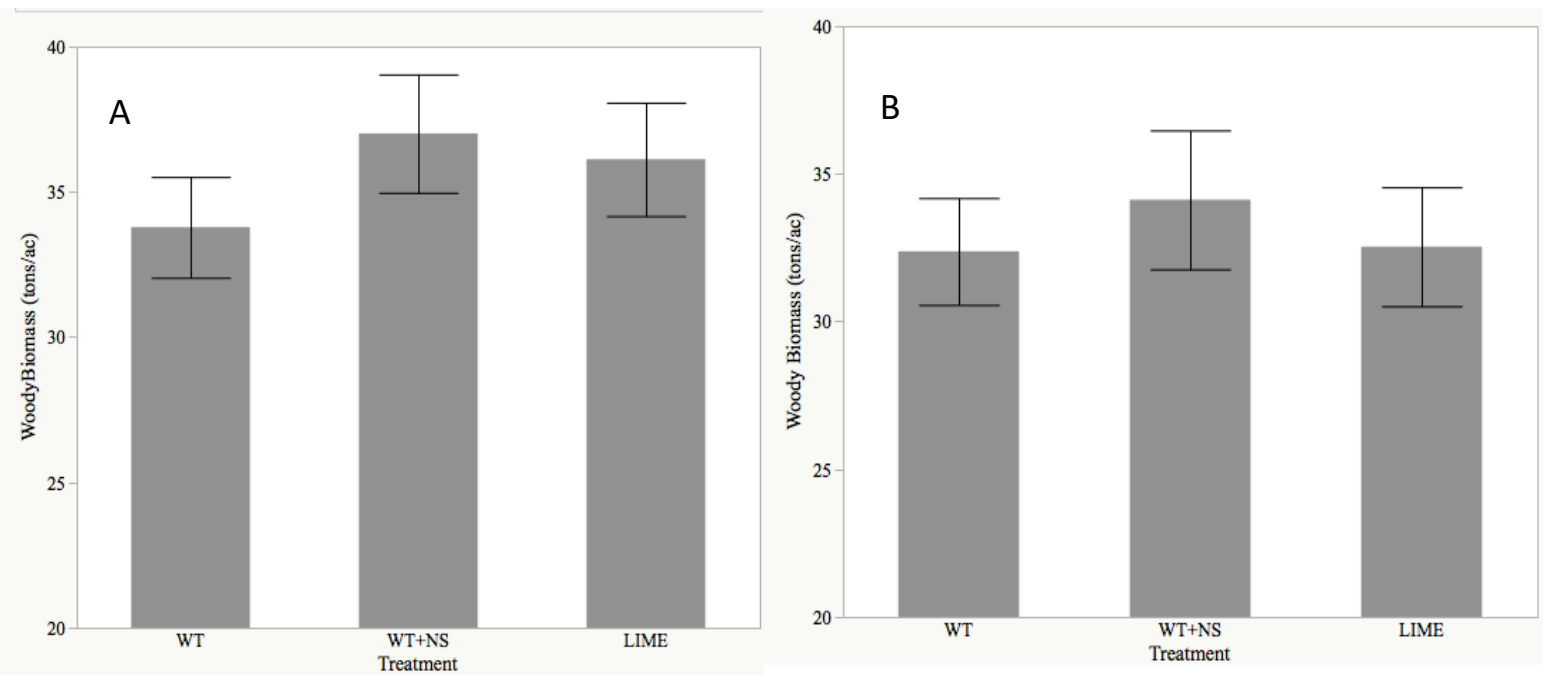

Figure 7. A) Total aboveground woody biomass (tons/ac) by treatment for all trees measured (F $=0.7605, \mathrm{P}=0.4721)$, and $\mathrm{B})$ for the six species with highest $\mathrm{RIV}$ values $(\mathrm{F}=0.4215, \mathrm{P}=$ 0.6566). Error bars represent 1 standard error of the mean.

There was no interaction between the six tree species and the treatments $(\mathrm{F}=1.0691, \mathrm{P}=$ 0.4027) in terms of trees per acre (Figure 8). There was a non-significant trend in the number of yellow-poplar trees growing in non-fertilized plots (WT) compared to the WT+NS and LIME plots $(\mathrm{F}=2.7619, \mathrm{P}=0.0726)$. However, there was not a significantly greater number of yellow-poplar seedlings per acre $(\mathrm{F}=0.5382, \mathrm{P}=0.5866)$ that germinated on the WT plots in the 1997 regeneration inventory (Table 2). There were more black cherry seedlings initially in the LIME plots compared to the other two treatments $(\mathrm{F}=3.8936, \mathrm{P}=0.0257)$, but that initial difference did not result in more black cherry stems on the LIME plots after 21 years $(\mathrm{F}=0.9648$, $\mathrm{P}=0.3879)$. Density $(\mathrm{TPA})$ did not differ by treatment $(\mathrm{F}=0.7802, \mathrm{P}=0.4637)$, but the main effect of species was statistically significant $(\mathrm{F}=8.7177, \mathrm{P}<0.0001)$. 


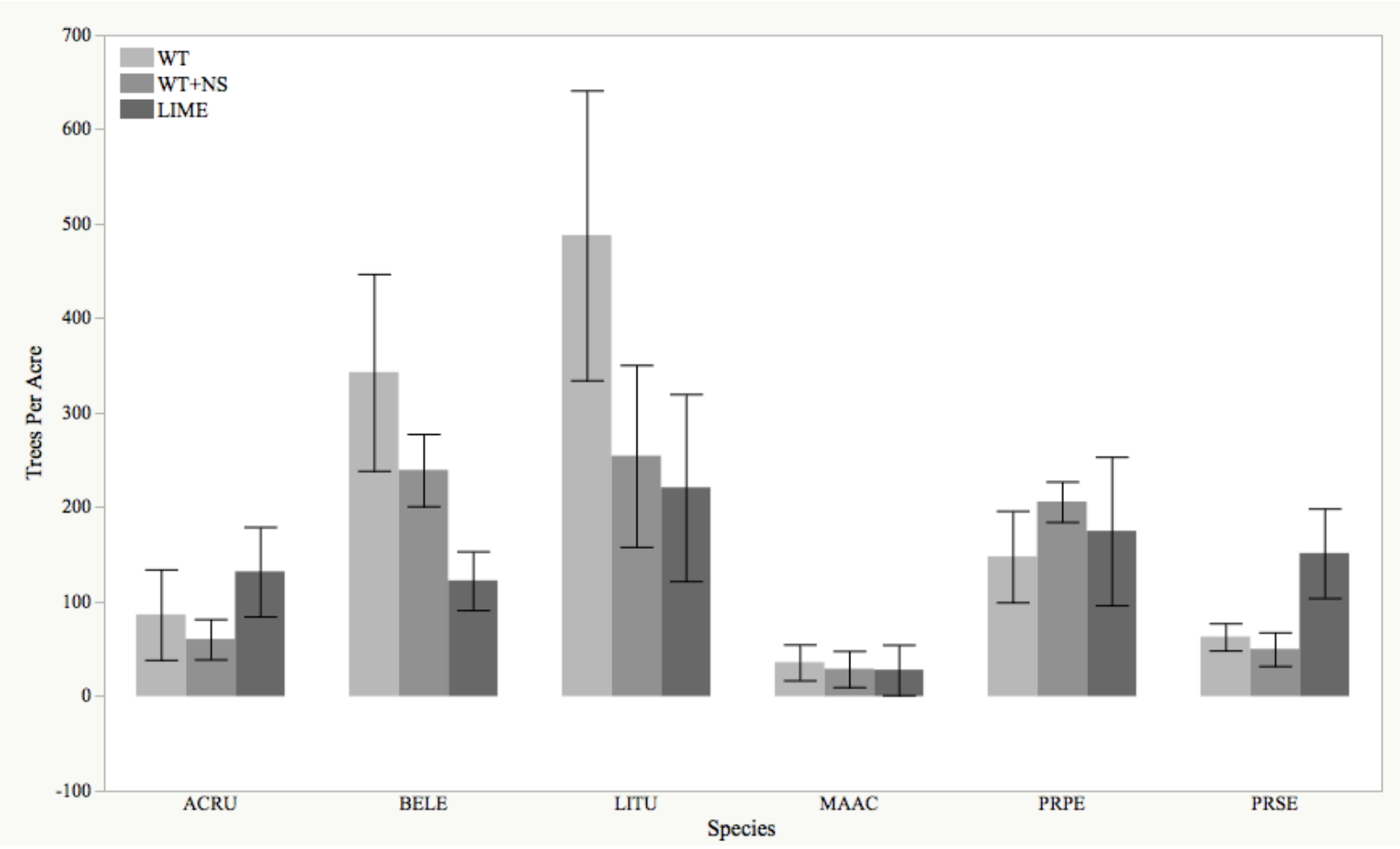

Figure 8. Trees per acre of the six species with highest RIV on site. Species by treatment interaction $(\mathrm{F}=1.0691, \mathrm{P}=0.4027)$. Error bars represent 1 standard error of the mean.

Table 2. Seedlings per acre (for six current species of highest RIV) measured in regeneration survey of all 20 permanent rods within each treatment plot in 1997. Asterisk $(*)$ designates significant difference at $\mathrm{P}=0.05$.

\begin{tabular}{cccc}
\hline Species & WT & WT+NS & LIME \\
\hline Acer rubrum & 5941 & 6035 & 5108 \\
Betula lenta & 1484 & 1393 & 2606 \\
Liriodendron tulipifera & 40888 & 27606 & 32201 \\
Magnolia acuminata & 1814 & 1250 & 1671 \\
Prunus pennsylvanica & 8690 & 6920 & 10319 \\
Prunus serotina & 22093 & 29288 & $56488^{*}$ \\
All Other Species & 5196 & 9182 & 8242 \\
\hline
\end{tabular}

No treatment differences were noted for quadratic mean diameter of any of the species (Figure 9). Although there was no interaction between species and treatment $(\mathrm{F}=0.2618, \mathrm{P}=$ 0.9867), the main effect of species was significant $(F=14.3634, P<0.0001)$. Pin cherry stems 
had the largest QMD in all treatment areas with diameters at least 1.5 times larger than all other species.

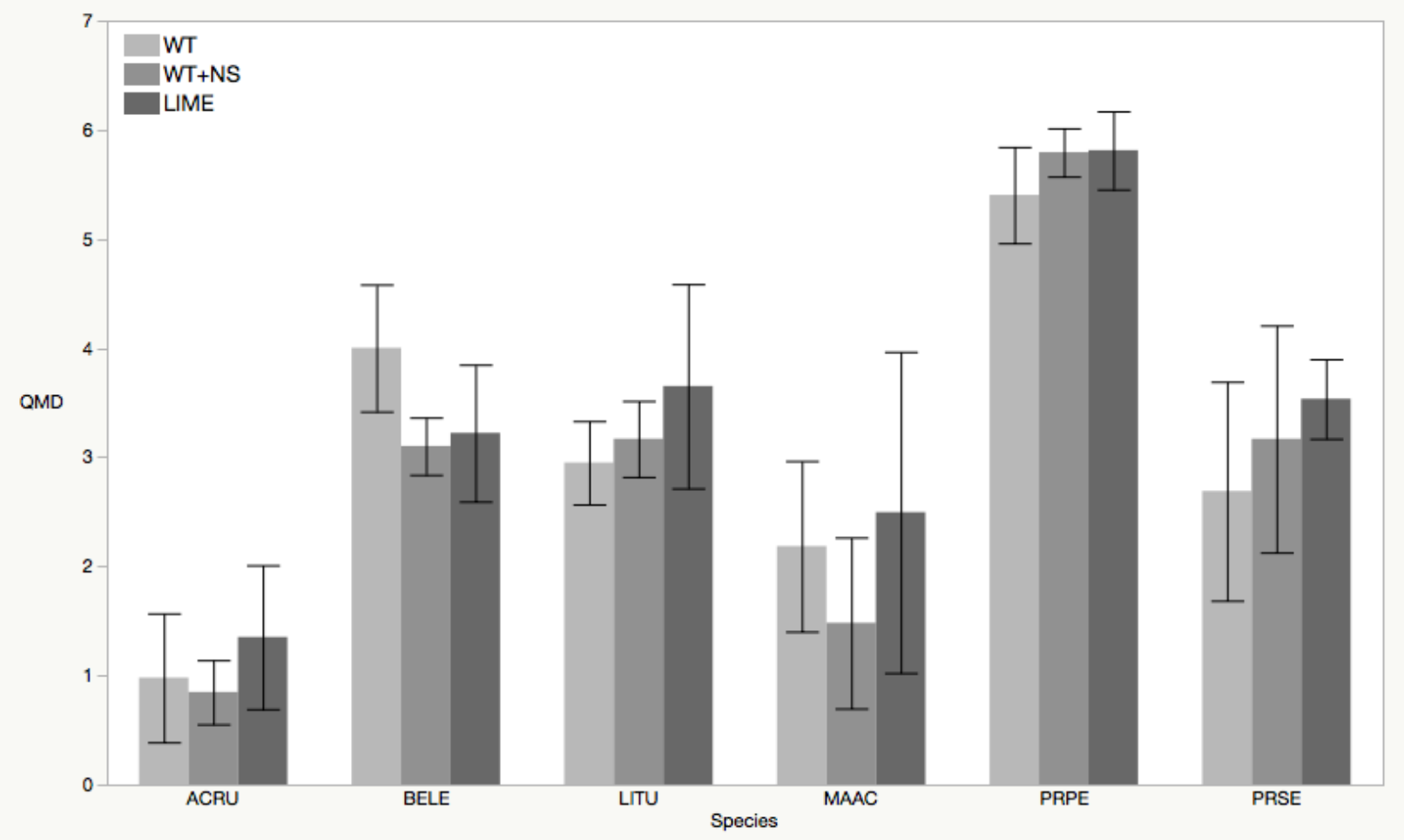

Figure 9. Quadratic mean diameter of the six species with highest RIV on site. Species by treatment interaction $(\mathrm{F}=0.8771, \mathrm{P}=0.5554)$. Error bars represent 1 standard error of the mean.

There was no interaction of time and treatment on total aboveground biomass $(\mathrm{F}=0.17$, $\mathrm{P}=0.9533)$ (Figure 10). The main effect of year was significant $(\mathrm{F}=7.44, \mathrm{P}=0.0044)$, but treatment was not $(F=0.15, P=0.8599)$. In 2017 the woody biomass/ac was slightly higher for the WT+NS and LIME treatments compared to the WT treatment. The 2009 data showed a reduction in average biomass per acre on $\mathrm{WT}+\mathrm{NS}$ plots. However, of note is the extremely high variability in the data collected in 2009. 


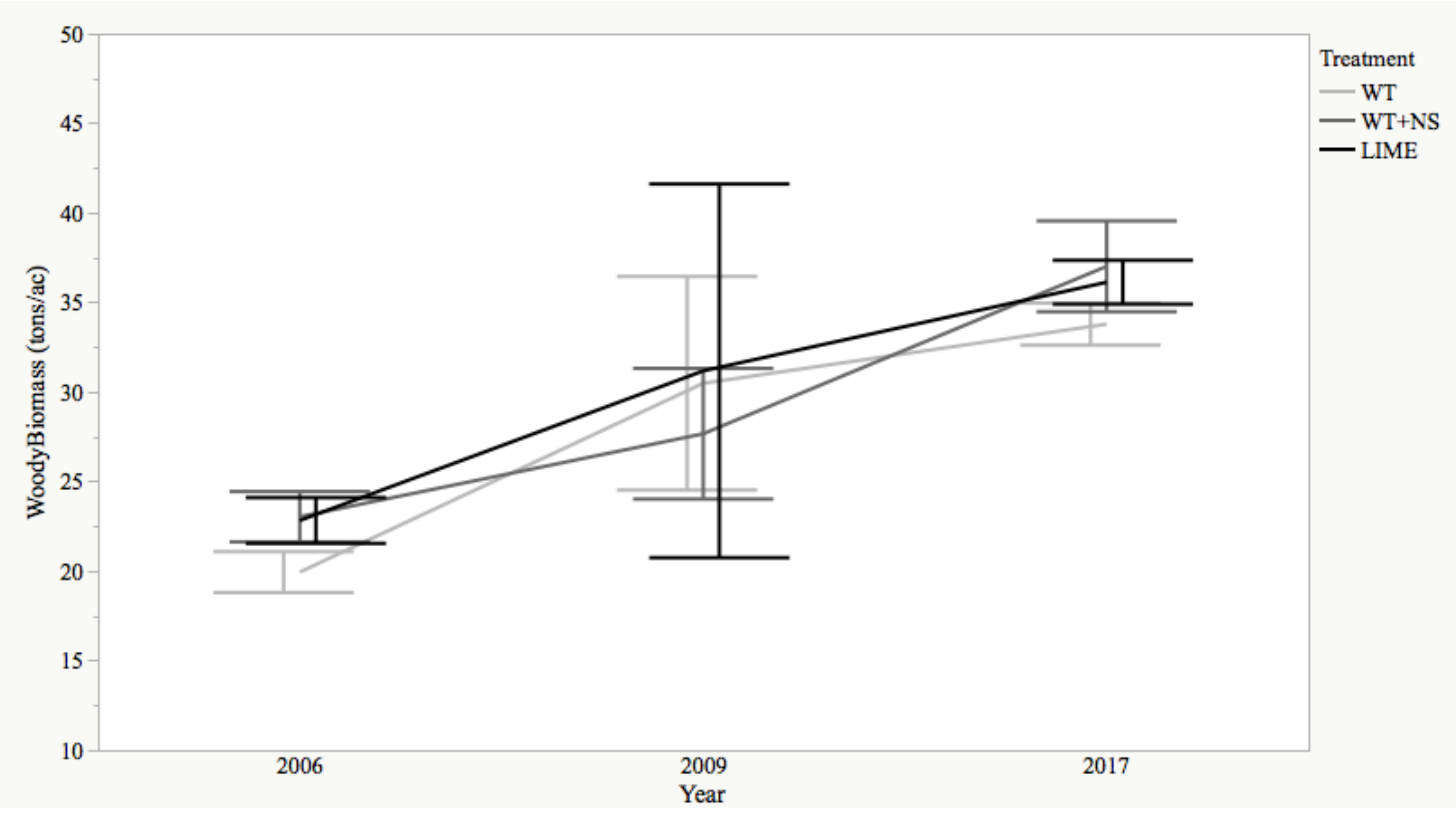

Figure 10. Change in treatment effect on aboveground biomass accumulation (tons/ac) over the last 11 years $(\mathrm{F}=0.17, \mathrm{P}=0.9533)$ Error bars represent 1 standard error of the mean.

\section{$\underline{\text { Discussion }}$}

The forest community in the Fork Mountain LTSP is at a dynamic point in its development. High mortality of pin cherry has reduced its relative importance by nearly half since 2009 (Table 1). Yellow-poplar, the species that has increased the most in RIV between 2009 and 2017, has trended towards fewer numbers of trees in the WT+NS and LIME plots (Figure 8). If the trends in replacement of pin cherry continue, then it is possible that the future species composition of the fertilized areas could be different than that of the non-fertilized areas.

We have measured an increase in species richness on the plots receiving dolomitic lime (Figure 5). This change suggests that the acidification effect of the ammonium sulfate treatments has affected the ability of certain species to develop and or persist on site. Interestingly, although there has not been much focus on sugar maple in this study due to its low abundance in 
the LTSP plots, the only occurrences of sugar maple were in plots receiving dolomitic lime. Three of the four LIME treatment plots have at least one occurrence of a sugar maple tree greater than 1" dbh. In the pre-treatment regeneration survey (Adams et al., 2004), sugar maple was found on all 16 of the plots on the site.

Under normal growing conditions sugar maple should persist in the areas where it originally occupied, if the only inhibition to growth was competition for light resources. Currently there is no measured difference in the abundance of pin cherry in the treatment areas (Figure 8) that may cause sugar maple mortality by exclusion (Nyland et al., 2007). In addition, there were no differences in initial pin cherry stems on any of the treatment areas (Table 2), so it does not seem likely that pin cherry would have excluded sugar maple to a greater extent in any one treatment area. It seems more likely that increased base cation availability in the soil on LIME plots (Fowler, 2014) has allowed sugar maple stems to persist in the stand. This finding would corroborate with other studies that have found decline of sugar maple in areas of accelerated base cation loss (Drohan et al., 2002; Duchesne et al., 2002; Houston, 1999).

Our results express the complexity of the interaction between increased nitrogen and sulfur in a forested system and the growth response of the overstory community. There is no difference in the total biomass accumulated among any of the treatment areas after 21 years (Figure 7). Considering increased aboveground $\mathrm{C}$ was measured on the WT+NS and LIME plots in the past (Fowler et al., 2015), perhaps the effects of the chronic $\mathrm{N}$ additions have begun to negatively influence the productivity of fertilized trees (Aber et al., 1998).

It is important to note the difference in response of the short-lived species (pin cherry) compared to the longer-lived species present on site. Although not statistically significant effect 
$(\mathrm{F}=1.7644, \mathrm{P}=0.1816)$, pin cherry accumulated an average of 5 tons/ac and 8 tons/ac more aboveground woody biomass on the LIME and WT+NS respectively, compared to the WT plots. This result supports the designation of pin cherry as an extreme case of an exploitive species (Bormann \& Likens, 1979), which is a species that can take advantage of high amounts of available nutrients in the soil. In comparison to the other five species of highest RIV, there were a similar number of trees per acre of pin cherry (Figure 8), however the trees were consistently larger, with relatively low variability in diameter (Figure 9). This suggests that the life strategy for concentrating growth allocation to stem portions of the tree is still paying off for the fastest growing individuals on the fertilized plots. Further investigation into the extremely low variability in pin cherry biomass on the WT+NS plots (Figure 6), revealed that pin cherry was observed on every WT+NS subplot. No other species was found on all subplots of a particular treatment. The increased $\mathrm{N}$ could allow the species to persist longer in the overstory, relative to pin cherries growing in the non-fertilized areas (Fahey et al., 1998). The trees growing on plots that are not receiving the additional available $\mathrm{N}$ may no longer be able to effectively compete for nutrients with species that have invested more energy into root growth (Fahey et al., 1998). This has resulted in higher mortality and lower yields of biomass on a per acre basis for the WT treatment area in comparison in the fertilized plots.

One species on the LTSP site which has had a surprising response to the fertilizer additions was yellow-poplar. There was no difference in the amount of aboveground biomass ( $F$ $=1.0055, \mathrm{P}=0.3730)$ or the average size of the individuals $(\mathrm{F}=0.2567, \mathrm{P}=0.7746)$ in the fertilized areas compared to the WT areas. Yellow-poplar has been identified as a species that responds positively to pulse fertilizer applications in both mature (Auchmoody \& Smith, 1977) and immature stands (Broadfoot \& Ike, 1968; Jacobs, Salifu, \& Seifert, 2005). However, long- 
term additions of ammonium sulfate resulted in decreased incremental growth of yellow-poplar (DeWalle et al., 2006). At years 10 and 13 on the LTSP site, the addition of dolomitic lime appears to mitigate and even reverse the negative effects of chronic additions of ammonium sulfate (Fowler et al., 2015; Johnson et al., 2010). However, in our study, after 21 years lack of difference in aboveground biomass (Figure 6) for yellow-poplar trees on the LIME plots suggests the mitigation of negative effects of the treatments by lime may be short-lived.

There was a trend towards higher density of yellow-poplar trees on the WT plots compared to the WT+NS and LIME plots (Figure 8). It does not seem likely that this response was due to the initial stand conditions in the regeneration survey (Table 2). Increased levels of available $\mathrm{N}$ in the fertilized plots (Fowler, 2014) could stimulate competition in these areas. Accelerated self-thinning on sites with higher nutrient availability compared to sites with lower nutrient availability is known as the Sukatchew effect (Harper, 1977) and could be a possible explanation for the trend of decreased yellow-poplar density on fertilized plots.

Our test for the differences in treatment response from 2006 - 2017 showed no difference $(\mathrm{P}=0.9533)$ in total aboveground biomass accumulated. At the time of the first (2006) and third (2017) measurements, the biomass that had accumulated on the WT+NS and LIME plots was greater than the control. There was a non-significant decrease in total amount of biomass accumulated in the WT+NS treatment areas (Figure 10) in the intermediate measurement period (2009). However, this trend did not persist as the stand continued to grow over the next 8 years. This suggests that the tree community in the fertilized areas have not yet reached the where the negative effects of the soil acidification and nitrogen saturation have become more influential than the direct positive increase in growth from the fertilizer.

Perhaps annual growth data may be more appropriate for determining the point at which 
the individual trees begin to respond negatively to the treatments. Using the approach in this study, it will take some time for the non-fertilized individuals to surpass the increased biomass that was accumulated from the initial growth stimulation of the fertilizer. Thus we may be exaggerating the amount of time it takes for chronic nitrogen additions to negatively affect tree growth. Changes in tree core trends from the dominant species would allow the investigator to more accurately determine the length of time of positive response, as well as the extent of the negative response.

I would be remiss to not address the extremely high variability in the aboveground biomass calculated for the 2009 dataset, in comparison to those calculated for the other two measurement periods (Figure 10). In order to compare all 3 of these data sets we had to expand all data to a per acre basis. In the case of the 2009 dataset, the plot size was slightly variable, but on average the square plots were approximately $0.02 \mathrm{ac}$. It seems that at this point in time there were some trees of significant size that were measured on these relatively small plots, along with a high abundance of smaller stems. If a plot had a few larger trees, and the density of small trees was high, the summed values of what that plot represented on a 1 acre basis had the potential of being very large (maximum of approximately 91 tons/ac). By contrast, plots that had a low density of smaller stems had very low aboveground biomass values (minimum of approximately 4 tons/ac).

The issue of differing sampling may also have adversely affected the statistical power of the repeated measures ANOVA. Different subplots were measured across the three inventories, so the common experimental unit across all years was the treatment plot $(n=12)$. With this low of a number of experimental units, the power of the test to detect the effect of the treatments was only about 0.14 . The differences in the treatment means would have had to be large to 
statistically show that the treatment effect has changed over time.

In summary, after 21 years of additions of ammonium sulfate and lime to a young aggrading central Appalachian forest, aboveground biomass accumulation does not differ among the treatments. The complexity of the response of individual species to these additions will be of particular interest moving forward. As pin cherry continues to decline in relative importance value, longer lived species such as yellow-poplar, sweet birch and black cherry will continue to increase in importance. Yellow-poplar has shown a negative trend in the number of trees per acre in treatment areas with increased nitrogen, which raises questions over the future composition of areas affected by elevated levels of $\mathrm{N}$ deposition. A decrease in species richness has occurred on the WT and WT+NS treatment areas, suggesting that background as well as increased levels of acidic deposition may lead to decreased occupancy of sensitive species in affected areas of the region. 


\section{Literature Cited:}

Aber, J. D., McDowell, W., Nadelhoffer, K., Magill, A., Berntson, G., Kamakea, M., ... Fernandez, I. (1998). Nitrogen saturation in temperate forest ecosystems - Hypotheses revisited. Bioscience, 48(11), 921-934.

Aber, J. D., Melillo, J. M., Nadelhoffer, K. J., Pastor, J., \& Boone, R. D. (1991). Factors Controlling Nitrogen Cycling and Nitrogen Saturation in Northern Temperate Forest Ecosystems. Ecological Applications, 1(3), 303.

Aber, J. D., Nadelhoffer, K. J., Steudler, P., \& Melillo, J. M. (1989). Nitrogen Saturation in Northern Forest Ecosystems. BioScience, 39(6), 378-386.

Adams, M. B., Burger, J., Zelazny, L., \& Baumgras, J. (2004). Description of the Fork Mountain Long-Term Soil Productivity Study: Site characterization, 43.

Adams, M. B., \& Kochenderfer, J. N. (2015). The Fernow Experimental Forest and Canaan Valley: A History of Research. Southeastern Naturalist, 14(7), 433-440.

Adams, M. B., Kochenderfer, J. N., \& Edwards, P. J. (2007). The Fernow watershed acidification study: Ecosystem acidification, nitrogen saturation and base cation leaching. Water, Air, \& Soil Pollution, 7, 267-273.

Allen, H. L., Dougherty, P. M., \& Campbell, R. G. (1990). Manipulation of water and nutrients - Practice and opportunity in Southern U.S. pine forests. Forest Ecology and Management, $30(1-4), 437-453$.

Auchmoody, L. R. (1979). Nitrogen fertilization stimulates germination of dormant pin cherry seed. Canadian Journal of Forest Research, 9, 514-516.

Auchmoody, L. R. (1982). Response of young black cherry stands to fertilization. Canadian Journal of Forest Research, 12(2), 319-325.

Auchmoody, L. R., \& Smith, H. C. (1977). Response of yellow-poplar and red oak to fertilization in West Virginia. Soil Science Society of America Journal, 41(4), 803-807. https://doi.org/10.1016/S0378-1127(00)00421-7

Bauer, G. A., Bazzaz, F. A., Minocha, R., Long, S., Magill, A., Aber, J., \& Berntson, G. M. (2004). Effects of chronic $\mathrm{N}$ additions on tissue chemistry, photosynthetic capacity, and carbon sequestration potential of a red pine (Pinus resinosa Ait.) stand in the NE United States. Forest Ecology and Management, 196(1), 173-186.

Baumgardner, R. E., Lavery, T. F., Rogers, C. M., \& Isil, S. S. (2002). Estimates of the atmospheric deposition of sulfur and nitrogen species: Clean Air Status and Trends Network, 1990-2000. Environmental Science and Technology, 36(12), 2614-2629.

Boggs, J. L., McNulty, S. G., Gavazzi, M. J., \& Myers, J. M. (2005). Tree growth, foliar chemistry, and nitrogen cycling across a nitrogen deposition gradient in southern Appalachian deciduous forests. Canadian Journal of Forest Research, 35(8), 1901-1913.

Bormann, H. F., \& Likens, G. E. (1979). Pattern and process in a forested ecosystem : Disturbance, development, and the steady state based on the hubbard brook ecosystem 
study. New York : Springer-Verlag.

Briand, C. H., Campion, S. M., Dzambo, D. A., \& Wilson, K. A. (1999). Biomechanical properties of the trunk of the devil's walking stick (Aralia spinosa; Araliaceae) during the crown-building phase: Implications for tree architecture. American Journal of Botany, 86(12), 1677-1682.

Broadfoot, W. M., \& Ike, A. F. (1968). Research progress in fertilizing southern hardwoods. Forest Fertilization Theory and Pracice, 180-184.

Burnham, M. B., Cumming, J. R., Adams, M. B., \& Peterjohn, W. T. (2017). Soluble soil aluminum alters the relative uptake of mineral nitrogen forms by six mature temperate broadleaf tree species: possible implications for watershed nitrate retention. Oecologia, 185(3), 327-337.

Chojnacky, D. C., Heath, L. S., \& Jenkins, J. C. (2014). Updated generalized biomass equations for North American tree species. Forestry, 87(1), 129-151. https://doi.org/10.1093/forestry/cpt053

Cottam, G., \& Curtis, J. T. (1956). The Use of Distance Measures in Phytosociological Sampling. Ecology, 37(3), 451-460. https://doi.org/10.2307/1930167

Cronan, C. S., \& Grigal, D. F. (1995). Use of calcium/aluminum ratios as indicators of stress in forest ecosystems. Environmental Quality, 24(2), 209.

DeWalle, D. R., Kochenderfer, J. N., Adams, M. B., Miller, G. W., Gilliam, F. S., Wood, F., ... Sharpe, W. E. (2006). Vegetation and acidification. In M. B. Adams, J. N. Kochenderfer, \& J. L. Hom (Eds.), The Fernow watershed acidification study (pp. 137-188).

Driscoll, C. T. ., Lawrence, G. B. ., Bulger, A. J. ., Butler, T. J. ., Cronan, C. S. ., Eagar, C. ., ... Weathers, K. C. . (2001). Acidic deposition in the northeastern United States: Sources and inputs, ecosystem effects, and management strategies. BioScience, 51(3), 180-198.

Drohan, P. J., Stout, S. L., \& Petersen, G. W. (2002). Sugar maple (Acer saccharum Marsh.) decline during 1979-1989 in northern Pennsylvania. Forest Ecology and Management, $170(1-3), 1-17$.

Duchesne, L., Ouimet, R., \& Houle, D. (2002). Basal Area Growth of Sugar Maple in Relation to Acid Deposition, Stand Health, and Soil Nutrients. Journal of Environmental Quality, 31(1), 1676-1683.

Edwards, P. J., Williard, K. W. J., Wood, F., \& Sharpe, W. E. (2006). Soil Water and Stream Water Chemical Responses. In M. B. Adams, D. R. DeWalle, \& J. L. Hom (Eds.), The Fernow Watershed Acidification Study (pp. 71-136).

Elvir, J. A., Rustad, L., Wiersrna, G. B., Fernandez, I., White, A. S., \& White, G. J. (2005). Eleven-year response of foliar chemistry to chronic nitrogen and sulfur additions at the Bear Brook Watershed in Maine. Canadian Journal of Forest Research, 35, 1402-1410.

Fahey, T. J., Battles, J. J., \& Wilson, G. F. (1998). Responses of early successional northern hardwood forests to changes in nutrient availability. Ecological Monographs, 68(2), 183212. 
Fenn, M. E., Poth, M. a, Aber, J. D., Baron, J. S., Bormann, B. T., Johnson, D. W., ... Aug, N. (1998). Nitrogen Excess in North American Ecosystems : Predisposing Factors , Ecosystem Responses, and Management Strategies. Ecological Applications, 8(3), 706-733.

Fernandez, I. J., Rustad, L. E., Norton, S. A., Kahl, J. S., \& Cosby, B. J. (2003). Experimental Acidification Causes Soil Base-Cation Depletion at the Bear Brook Watershed in Maine. Soil Science Society of America Journal, 67(6), 1909-1919.

Fowler, Z. K. (2014). The effects of accelerated soil acidification on aggrading temperate deciduous forests: The Fernow Experimental Forest Long Term Soil Productivity (LTSP) Study at 13 years (Ph. D. Dissertation). Retrieved from ProQuest Dissertations and Theses Database. (UMI No. 3618381). West Virginia University.

Fowler, Z. K., Adams, M. B., \& Peterjohn, W. T. (2015). Will more nitrogen enhance carbon storage in young forest stands in central Appalachia? Forest Ecology and Management, $337,144-152$.

Fox, T., Allen, H., \& Albaugh, T. (2007). Tree nutrition and forest fertilization of pine plantations in the southern United States. Southern Journal of Applied Forestry, 31(1), 511.

Galloway, J. N., Dentener, F. J., Capone, D. G., Boyer, E. W., Howarth, R. W., Seitzinger, S. P., ... Vörösmarty, C. J. (2004). Nitrogen cycles: Past, present, and future. Biogeochemistry (Vol. 70). https://doi.org/10.1007/s10533-004-0370-0

Galloway, J. N., Likens, G. E., \& Edgerton, E. S. (1976). Acid precipitation in the Northeastern United States: $\mathrm{pH}$ and acidity. Science, 194, 722-724.

Gilliam, F. S., Adams, M. B., \& Yurish, B. M. (1996). Ecosystem nutrient responces to chronic nitrogen inputs at Fernow Experimental Forest, West Virginia. Canadian Journal of Forest Research, 26, 196-205.

Gilliam, F. S., Walter, C. A., Adams, M. B., \& Peterjohn, W. T. (2018). Nitrogen (N) Dynamics in the Mineral Soil of a Central Appalachian Hardwood Forest During a Quarter Century of Whole-Watershed N Additions. Ecosystems, (September 2017).

Graber, R. E., \& Thompson, D. F. (1978). Seeds in the organic layers and soil of four beechbirch-maple stands. Forest Service Research Paper NE-401, 1-10.

Hannah, P. R. (1991). Regeneration of northern hardwoods in the Northeast with the shelterwood method. Northern Journal of Applied Forestry, 8(3), 99-104.

Harper, J. L. (1977). Population Biology of Plants.

Harrington, James, F. (1972). Seed Storage and Longevity. In Seed Biology (3rd ed., pp. 145245). Academic Press.

Heitzman, E., \& Nyland, R. D. (1994). Influences of pin cherry (Prunus pensylvanica L. f.) on growth and developement of young even-aged northern hardwoods. Forest Ecology and Management, 67, 39-48.

Helvey, J. D., \& Kunkle, S. H. (1986). Input-output budgets of selected nutrients on an 
experimental watershed near Parsons, West Virginia. Res. Pap. NE-584. Broomall, PA: U.S. Department of Agriculture, Forest Service, Northeastern Forest Eperimental Station, 7.

Hibbs, D. E. (1983). Forty Years of Forest Succession in Central New England. Ecology, 64(6), 1394-1401. https://doi.org/10.2307/1937493

Houston, D. R. (1999). History of Sugar Maple Decline. Sugar Maple Ecology and Health: Proceedings of an International Symposium, GTR-NE-261, 19-26.

Huggett, B. A., Schaberg, P. G., Hawley, G. J., \& Eagar, C. (2007). Long-term calcium addition increases growth release, wound closure, and health of sugar maple ( Acer saccharum) trees at the Hubbard Brook Experimental Forest. Canadian Journal of Forest Research, 37(9), 1692-1700.

Jacobs, D. F., Salifu, K. F., \& Seifert, J. R. (2005). Growth and nutritional response of hardwood seedlings to controlled-release fertilization at outplanting. Forest Ecology and Management, $214,28-39$.

Jensen, V. S. (1943). Suggestions for Management of Northern Hardwood Stands in the Northeast. Journal of Forestry, (41), 180-185.

JMP. (n.d.). Version 13.0. SAS Institue Inc., Cary, NC, 1989-2007.

Johnson, B. A., Piatek, K. B., Adams, M. B., \& Brooks, J. R. (2010). Does Nitrogen and Sulfur Deposition Affect Forest Productivity. In Proceedings from the conference on the ecology and management of high-elevation forests in the central and southern Appalachian Mountains, General Technical Report NRS-P-64 (pp. 85-93).

Jokela, E. J., Allen, H. L., \& McFee, W. W. (1991). Fertilization of southern pines at establishment. In M. L. Duryea \& P. M. Dougherty (Eds.), Forest Regeneration Manual (pp. 263-277). Dordrecht: Springer.

Jokela, E. J., Wilson, D. S., \& Allen, J. E. (2000). Early Growth Responses of Slash and Loblolly Pine Following Fertilization and Herbaceous Weed Control at Establishment. Southern Journal of Applied Forestry, 24(1), 23-30.

Leak, W. B. (1988). Effects of weed species on northern hardwood regeneration in New Hampshire. Northern Journal of Applied Forestry, 5, 235-237.

Long, R. P., Horsley, S. B., \& Lilja, P. R. (1997). Impact of forest liming on growth and crown vigor of sugar maple and associated hardwoods. Canadian Journal of Forest Research, 27(10), 1560-1573.

Magill, A. H., Aber, J. D., Currie, W. S., Nadelhoffer, K. J., Martin, M. E., McDowell, W. H., ,.. Steudler, P. (2004). Ecosystem response to 15 years of chronic nitrogen additions at the Harvard Forest LTER, Massachusetts, USA. Forest Ecology and Management, 196, 7-28.

Marks, P. L. (1974). The Role of Pin Cherry ( Prunus pensylvanica L .) in the Maintenance of Stability in Northern Hardwood Ecosystems. Ecological Monographs, 44(1), 73-88.

Marquis, D. A. (1975). Seed Storage and Germination Under Northern Hardwood Forests. Canadian Journal of Forest Research, 5, 478-484. https://doi.org/10.1139/x75-065 
May, J. D., Burdette, S. B., Gilliam, F. S., \& Adams, M. B. (2005). Interspecific divergence in foliar nutrient dynamics and stem growth in a temperate forest in response to chronic nitrogen inputs. Canadian Journal of Forest Research, 35(5), 1023-1030.

McKeand, S. E., Jokela, E. J., Huber, D. A., Byram, T. D., Allen, H. L., Li, B., \& Mullin, T. J. (2006). Performance of improved genotypes of loblolly pine across different soils, climates, and silvicultural inputs. Forest Ecology and Management, 227(1-2), 178-184.

Miles, P. D., \& Smith, W. B. (2009). Specific Gravity and Other Properties of Wood and Bark for 156 Tree Species Found in North America. Res. Note. NRS-38, 35.

Morin, R. (2016). Forests of West Virginia , 2015, Resource Update FS-93. Newtown Square, PA: U.S.

Newton, L. P., Robison, D. J., Hansen, G., \& Allen, H. L. (2002). Fertilization and thinning in a 7-year-old natural hardwood stand in eastern North Carolina. Gen. Tech. Rep. SRS-48. Asheville, NC: U.S. Department of Agriculture, Forest Service, Souther Research Station, 193-195.

Nyland, R. D., Bashant, A. L., Heitzman, E. F., \& Verostek, J. M. (2007). Interference to Hardwood Regeneration in Northeastern North America: Pin Cherry and Its Effects. Northern Journal of Applied Forestry, 24(1), 52-60.

Peterjohn, W. T., Adams, M. B., \& Gilliam, F. S. (1996). Symptoms of Nitrogen Saturation in Two Central Appalachian Hardwood Forest Ecosystems. Biogeochemistry, 35(3), 507-522.

Pregitzer, K. S., Burton, A. J., Zak, D. R., \& Talhelm, A. F. (2008). Simulated chronic nitrogen deposition increases carbon storage in Northern Temperate forests. Global Change Biology, 14(1), 142-153.

Pritchett, W. L., \& Wells, C. G. (1978). Harvesting and site preparation increase nutrient mobilization. In T. Tippin (Ed.), Proceedings: A Symposium on Principles of Maintaining Productivity on Prepared Sites. Proc. Symp., Mar. 21-22, 1978. Miss. State Univ., U.S. For. Serv., S. For. Exp. Stn. (pp. 98-110). New Orleans, LA.

Richter, D. D., Johnson, D. W., \& Dai, K. H. (1991). Cation exchange and Al mobilization in soils. In D. W. Johnson \& S. E. Lindberg (Eds.), Atmospheric deposition and forest nutrient cycling (Vol. 91, pp. 341-377). Springer-Verlag, New York, New York, USA.

Ristau, T. E., \& Horsley, S. B. (1999). Pin cherry effects on Allegheny hardwood stand development. Canadian Journal of Forest Research-Revue Canadienne De Recherche Forestiere, 29(1), 73-84.

SAS Institute Inc. (n.d.). SAS 9.4, Cary, NC: SAS Institute Inc., 2002-2013.

Schaberg, P. G., Perkins, T. D., \& McNulty, S. G. (1997). Effects of chronic low-level N additions on foliar elemental concentrations, morphology, and gas exchange of mature montane red spruce. Canadian Journal of Forest Research, 27(10), 1622-1629.

Schaberg, P. G., Tilley, J. W., Hawley, G. J., DeHayes, D. H., \& Bailey, S. W. (2006). Associations of calcium and aluminum with the growth and health of sugar maple trees in Vermont. Forest Ecology and Management, 223(1-3), 159-169. 
Schlesinger, W. H., \& Bernhardt, E. S. (2013). Biogeochemistry: An Analysis of Global Change (Third Edit). Elsevier.

Shortle, W. C., \& Smith, K. T. (1988). Aluminum-Induced Calcium Defficiency Syndrome in Declining Red Spruce. Science, 240(4855), 1017-1018.

Spiro, T. G., \& Stigliani, W. M. (2003). Chemistry of the Environment (2nd ed.). Prentice Hall.

Stanturf, J. A. (1989). Effects of added nitrogen on growth of hardwood trees in southern New York. Canadian Journal of Forest Research, 19(2), 279-284.

Steudler, P. A., Bowden, R. D., Melillo, J. M., \& Aber, J. D. (1989). Influence of nitrogen fertilization on methane uptake in temperate forest soils. Nature, 341(6240), 314-316.

Talhelm, A. F., Pregitzer, K. S., \& Burton, A. J. (2011). No evidence that chronic nitrogen additions increase photosynthesis in mature sugar maple forests. Ecological Applications, 21(7), 2413-2424.

Thiffault, E., Hannam, K. D., Paré, D., Titus, B. D., Hazlett, P. W., Maynard, D. G., \& Brais, S. (2011). Effects of forest biomass harvesting on soil productivity in boreal and temperate forests - A review. Environmental Reviews, 19(NA), 278-309.

Van Breemen, N., Burrough, P. A., Velthorst, E. J., Van Dobben, H. F., De Wit, T., Ridder, T. B., \& Reijnders, H. F. R. (1982). Soil acidification from atmospheric ammonium sulphate in forest canopy throughfall. Nature, 299(5883), 548-550.

Vance, E. D., Prisley, S. P., Schilling, E. B., Tatum, V. L., Wigley, T. B., Lucier, A. A., \& Van Deusen, P. C. (2018). Environmental implications of harvesting lower-value biomass in forests. Forest Ecology and Management, 407, 47-56.

Vitousek, P. (1982). Nutrient Cycling and Nutrient Use Efficiency. The American Naturalist, 119(4), 553-572.

Wallace, Z. P., Lovett, G. M., Hart, J. E., \& Machona, B. (2007). Effects of nitrogen saturation on tree growth and death in a mixed-oak forest. Forest Ecology and Management, 243(2-3), 210-218.

Walter, C. A. (2016). Does enhanced nitrogen input affect the structure and composition of forest vegetation? Results from long-term experiments at the Fernow Experimental Forest (Ph. D. Dissertation). Retrieved from ProQuest Dissertations and Theses Database. (No 10110177), 175.

Wang, Z., \& Nyland, R. D. (1996). Changes in the Condition and Species Composition of Developing Even-Aged Northern Hardwood Stands in Central New York. Northern Journal of Applied Forestry, 13(4), 189-194. 
Chapter 3. Use of a Locally Calibrated and Validated Forest Growth Model to Project 40 Years of Species Specific Responses to Chronic Additions of Nitrogen, Sulfur and Lime. 


\section{Introduction:}

The influence of acid rain on the health and productivity of forest ecosystems has been a topic of research interest since the late 1970’s - early 1980’s (Johnson, 1983; Johnson \& Siccama, 1983; Ulrich, 1982). High concentrations of coal fired power plants in the Ohio River valley have historically been a major source of nitrous oxides $\left(\mathrm{NO}_{\mathrm{x}}\right)$ and sulfur oxides $\left(\mathrm{SO}_{\mathrm{x}}\right)$, that were released into the atmosphere. These gases are released from the combustion of fossil fuels and once in the atmosphere both gases have a high affinity for water vapor and quickly form the most common forms of acid rain: nitric $\left(\mathrm{HNO}_{3}\right)$ and sulfuric $\left(\mathrm{H}_{2} \mathrm{SO}_{4}\right)$ acids (Galloway et al., 1976). Due to the relatively short mean residence time of water in the atmosphere, these acids are deposited in the form of acidic precipitation across the mid-Atlantic and northeastern United States.

When nitric and sulfuric acids are deposited into forested areas in the Central Appalachian region, they have both direct and indirect negative influences on the associated forest soils. A large percentage of the soils of the central Appalachian hardwood forest region are at risk for base cation depletion from soil acidification and nitrogen saturation (Adams et al., 2000). These soils are normally low in base cations such as calcium $\left(\mathrm{Ca}^{2+}\right)$ and magnesium $\left(\mathrm{Mg}^{2+}\right)$, which also limits their buffering capacity (Spiro \& Stigliani, 2003). As $\mathrm{H}_{2} \mathrm{SO}_{4}$ and $\mathrm{HNO}_{3}$ deposition increases, hydrogen ions $\left(\mathrm{H}^{+}\right)$disassociate in soil solution, which increase rates of mineral weathering and displace cations from cation exchange sites (Schlesinger \& Bernhardt, 2013). Additionally, $\mathrm{H}^{+}$ions associate with aluminum $\left(\mathrm{Al}^{3+}\right)$ bearing compounds, increasing the amount of aluminum ions in soil solution, which negatively affects root growth (Foy et al., 1978; Foy et al., 1984). Aluminum ions have a high affinity for CEC sites and displace plant essential cations such as $\mathrm{Ca}^{2+}$ and $\mathrm{Mg}^{2+}$ (Schlesinger \& Bernhardt, 2013). If not taken up by plants rather 
quickly, calcium and magnesium ions are leached from the soil, further decreasing soil fertility (Driscoll et al., 2001). Increased $\mathrm{Al}^{3+}$ concentrations in soil can also reduce the rate of nitrate $\left(\mathrm{NO}_{3}^{-}\right.$) uptake by trees, allowing increased $\mathrm{NO}_{3}^{-}$leaching from soils (Burnham et al., 2017).

A secondary process associated with the deposition of nitric acid is nitrogen saturation. When inputs of nitrogen from the atmospheric deposition, mineralization, and atmospheric sequestration become greater than the need of the organisms in the system (Aber et al., 1989) an ecosystem can be considered $\mathrm{N}$ saturated. Excess nitrate is leached from the soil due to the low capacity of central Appalachian forests to retain nitrate (Peterjohn et al., 1996). As systems reach nitrogen saturation, the nitrification of ammonium $\left(\mathrm{NH}_{4}{ }^{+}\right)$to nitrate increases, leading to additional losses of $\mathrm{N}$ from the system. (McNulty et al., 1991). Other negative effects of increased Ninclude lower soil pH values (Van Breemen et al., 1982), reduced base cation uptake due to $\mathrm{Al}^{3+}$ mobilization (Cronan \& Grigal, 2004; Richter et al., 1991), and increased release of greenhouse gas emissions from soils (Steudler et al., 1989).

The response of forests to inputs of chronic $\mathrm{N}$ and Sulfur (S) are dependent on location and duration of the inputs. In central Appalachian forests, commercially important species such as yellow-poplar (Liriodendron tulipifera) showed decreased incremental growth after 7 years of nitrogen and sulfur inputs (DeWalle et al., 2006). Similarly, biomass accumulation by sweet birch (Betula lenta) and yellow-poplar decreased in areas with increased chronic $\mathrm{N}$ inputs (Fowler et al., 2015) . Fowler et al., (2015) concurrently observed a decrease in species diversity on a central Appalachian site receiving elevated rates of $\mathrm{N}$ and $\mathrm{S}$. However, the total plant biomass of a forest community can be stimulated by sustained increases in nitrogen inputs (Adams et al., 2007; Magill et al., 2004; Pregitzer et al., 2008). The extent and duration of these responses are variable and species-specific, but eventually the negative effects of soil 
acidification are theorized to outweigh the positive effect of increased nitrogen availability (Aber et al., 1998).

The long-term effects of elevated acidic deposition on forest growth and health have been studied to a lesser extent. In this study, I focused on projecting the growth of overstory trees located in the Fernow Experimental Forest, that are receiving chronic additions of nitrogen and sulfur to gain a better understanding of the possible long-term impacts of the treatments. I employed a forest growth and yield model (Forest Vegetation Simulator Northeast Variant) to project current growth trends across a time period of 40 years. Local data were used to calibrate and validate the FVS model to growth patterns observed within the Fernow Experimental Forest. We hope this study will lead to increased use of the FVS model in practice and research in central Appalachian forest systems, as well as give us a better understanding of the potential long-term impacts of increased acidic deposition.

\section{Literature Review:}

\section{Review of Forest Growth and Successional Models}

Forests are dynamic systems, changing along a timeline due to biological, chemical, geological and anthropogenic influences. The complexity of these systems presents an inherent difficulty in trying to predict the future conditions of a forest. The study of plant succession has been a topic of ecological debate for over a hundred years (Clements, 1916). Succession can be described as a trend towards an increase in uniformity of species composition resulting from the influence of dominant species present in the pioneer community (Christensen \& Peet, 1984). One hypothesis for this process is a type of "relay succession", where each group of later successional species takes over for the previous group in a distinct transition (Egler, 1954). 
Egler (1954) also proposed the initial floristics model of succession, where all species present at the end of the successional pathway were also present (but usually as a smaller component) at the beginning of the timeline. As each previous group of species begins to decline in dominance, another group of species begins to increase in dominance, persists for a period of time, and then is replaced by the next successive group of species. The climax of the process is a stable system, composed of long-lived species that will likely dominate until a disturbance. Forest succession is complicated, consisting of a mix of the concepts proposed by Egler, with the majority of species present at the end of the pathway also having been there in the beginning, and a smaller component of the system resulting from the dispersal of seeds into the system (Hibbs, 1983).

In modern terms, succession can been broken down into 3 distinct concepts: pathways, mechanisms and models (Pickett et al., 1987). The pathways of succession are the pattern of vegetation change over time. Successional pathways can be used describe the change in dominance of a particular species, the replacement by other species and the change from one forest development stage to another (Taylor et al., 2009). The mechanisms of succession are the factors that are involved in causing successional pathways to take place. They are the underlying processes in the ecosystem that drive the changes we see as succession. Successional models are a framework in which successional mechanisms have been implemented and described along a timeline of development stages of the pathway. They do not aim to describe every process of the natural system, but rather to implement a simplified explanation of changes that will represent what has been observed.

Despite the complexity of forest ecosystems, forest growth and successional models have been developed based on our understanding of the underlying relationships and mechanisms of forests and have been widely used to predict future forest conditions. These models can be useful 
in management for predicting future species composition, the value of stands, as well as understanding the implications of possible changing environmental conditions on forest communities. These models are crucial in successful management of forest resources on both the stand and landscape level. Generally, quantitative forest succession models are broken down into two broad classifications: individual or gap models and forest landscape models (Larocque et al., 2016).

Landscape level models are used to characterize the role of large scale disturbances on landscape ecosystem dynamics for use in decision making. These models are generally used for areas larger than a single forest stand, have coarse spatial resolution and operate on fairly long time steps (Taylor et al., 2009). They incorporate multiple layers of environmental data for the study area and generally produce an output in raster form that can be viewed in a GIS system (Larocque et al., 2016). A very commonly used forest landscape model in the western US is LANDIS (Mladenhoff, 1993), with the major focus of model use being the prediction of largescale disturbances such as fire. The model operates by predicting succession of species composition within the cells on a grid, based on the environmental input layer files (Mladenoff, 2004). Due to the coarse spatial scale of these types of models, they are generally not applicable for stand-level management.

Gap based models are used for stand level projections and are classified normally first by the species composition (single or multi-species), secondarily whether they were designed for even or mixed aged stands, and lastly whether they are distance dependent or independent (Liu \& Ashton, 1995; Herman H. Shugart, 1984). Early models were developed in the 1960's for forest growth and yield purposes but were later adapted for ecological uses (Larocque et al., 2016). Gap models simulate growth of individual trees using empirical relationships in a spatial unit 
called a gap, which occupies a specified area or space. All the gaps collectively are then are used to describe the growth, mortality and regeneration within a stand. These three components also allow the model to predict succession as the plots move through time. Early examples of distance independent gap models for predicting growth, mortality and regeneration included JABOWA (Botkin et al.,1972) and JABOWA-FORET (Shugart \& West, 1977). The framework of these two models have been used to create a series of other models designed for other geographical areas (Leemans \& Prentice, 1987; Shugart et al., 1980) and to include organic matter and nitrogen dynamics of forests (Aber \& Melillo, 1982).

Individual tree models vary slightly from gap models in the sense that the individual tree is what is actually being simulated and thus reported. These models are also referred to as hybrid models due to their balance between robust empirical relationships and theoretical knowledge, and have been touted for their flexibility and suitability in forest management planning (Taylor et al., 2009). Like gap models these models are either developed as distance independent or dependent, where distance dependent models utilize the relative position of the trees to each other to determine their competitive success. SORTIE (Pacala et al., 1993) is a spatially explicit model developed to simulate successional dynamics in the mixed hardwood forests of northeastern United States. The model's growth and mortality parameters have been empirically calibrated and validated (Pacala et al., 1993; Pacala et al., 1996) and successfully modified to be used in other regions (Coates et al., 2003; Sprugel et al., 2009). However, the nature of the sampling required (whole stand stem map) for the model is quite intensive, especially in young forests with high tree densities. For this reason, it may be deemed an impractical tool by forest managers and researchers on a limited budget of both time and money. 
Distance independent hybrid models utilize more commonly available data (plot samples) to grow individual trees based on silvicultural knowledge and empirical growth functions (Taylor et al., 2009). These models grow individual trees and expand those values to a per unit area basis for each stand, making a simple output that can be readily utilized by managers. These types of models are also flexible, and can be modified for local environmental conditions. An

early example of a distance independent tree model, Prognosis (Stage, 1973), was developed by the US Forest Service to provide managers with a tool to better understand the development of pure and mixed species stands in Rocky Mountain forests. The model has been modified by expanding the region of calibration to improve prediction response in other geographic areas. It has also been used to describe the impact of insects and pathogens on forest as well as to describe treatment effects in managed stands (Wykoff et al., 1982).

\section{Use of the Forest Vegetation Simulator for Forest Growth Projections}

The Forest Vegetation Simulator (FVS) (Crookston \& Dixon, 2005; Dixon, 2002;

Wykoff et al., 1982) is a distance independent individual tree model developed by the US Forest Service (USFS) from the aforementioned Prognosis Model. Since the USFS adopted the model as its supported growth and yield tool, it has been used extensively by both government and private managers. Over the past few decades, 20 regional variants of the model have been created for various forest regions across North America. Additionally, a multitude of extensions have been added to FVS to better simulate silvicultural treatments and natural disturbances (insect and disease outbreaks, fire) as well as create reports that include carbon, climate and economic data for individual stands. The model has also been updated to include the Suppose interface (Crookston, 1997), which is a platform used to input management guidelines and modify the base model. Suppose also includes customizable post processing tools that can be 
used to create outputs such as tree list files, 3-D stand visualization images, stand stock tables and calibration statistics.

These additions to the FVS system have made it an extremely useful tool for researchers and mangers alike. Although variants have been produced to cover the entire geographic region of the continental US and Alaska, there exists a high degree of variation in the growing conditions and species compositions within each regional variant. Base model bias has been shown repeatedly (Brand \& Holdaway, 1989; Brooks \& Miller, 2011; Canavan \& Ramm, 2000; Kowalski \& Gertner, 1989; Leites et al., 2009; Russell et al., 2013) for a variety of predicted variables due to variation in local growth conditions. In addition, there have been reports of reduced prediction accuracy as site index and length of projection increases (Lacerte et al., 2004). There is a clear precedence emphasizing the need to calibrate the model before implementation for research or management. Although, there has been some support for FVS base model performance (and its precursor models i.e. NE \& SE TWIGS) as being comparable and even less biased than other available eastern forest growth simulators (Rauscher et al., 2000; Schuler et al., 1993; Yaussy, 2000).

The US Forest Service has employed a FVS Steering Team to provide guidelines for users to calibrate and validate the variant base models to help reduce bias (Cawrse et al., 2009). Model performance has been shown to increase with parameter manipulation and calibration (Lacerte et al., 2006; Radtke et al., 2012). Lacerte et al., (2004) identified the mortality function as one of the key parameters that required local calibration to reduce bias and improve predictions of stand density and basal area. Results from an attempt to improve basal area predictions of the northeast FVS variant (FVS NE) by using dbh growth data were variable, depending on region and forest type (Russell et al., 2013). 
In this study I used FVS NE to predict plot-level growth of trees being exposed to experimental increased inputs of nitrogen, sulfur, calcium and magnesium at the Fernow Experimental Forest (FEF) LTSP site. I employed the guidelines for validation and calibration of the FVS NE model provided in literature to produce a model that adequately predicts growth in the highly productive forests of the FEF. Specific objectives of this analysis are to: 1) highlight parameters within FVS NE that require modification to reduce bias in growth predictions in the Fernow, 2) validate that the FVS NE can be modified with local growth data to produce reasonably accurate predictions of trees per acre (TPA) and ba/ac, 3) predict the longterm implications of chronic additions of ammonium sulfate and lime on important tree species of the central Appalachian forest region.

\section{Methods:}

\section{Study Areas}

This study was based in the USFS Fernow Experimental Forest near Parsons, West Virginia. The 4700 acre forest has been utilized as a research and teaching forest by the USFS since its establishment in 1934. Over this time period, key topics of long-term research have included silvicultural management for production of high quality hardwoods, the effects of harvesting on water quality, and ecosystem responses to acidic deposition. I will be utilizing a long-term dataset from some of the experimental harvest silvicultural studies to calibrate a model to local growing conditions in the Fernow to produce a better model for projecting the growth of trees being exposed to the acidic deposition treatments in the LTSP study area.

\section{$\underline{\text { Calibration Sites }}$}


I utilized growth data sets from 18 plots in 9 calibration stands located across the Fernow to calibrate the FVS NE growth model to local conditions (Figure 1). These stands were all regenerated using an even age seed tree regeneration method, with initial harvest occurring between August 1960 and August 1962. Initial harvests removed between $71-84 \mathrm{ft}^{2} \mathrm{ba} / \mathrm{ac}$ and resulted in the recruitment of sufficient numbers of trees to merit final seed-tree removal within 2-3 years of the initial harvests. The landscape features vary among sites (Table 1), but generally the plots range between 2,000 - 3,000 feet in elevation. The soils are typically characterized as moderately deep, well drained residuum that were formed from the weathering of shale, sandstone or siltstone. The Belmont series is the one exception, which was derived from mainly limestone (USDA, n.d.).

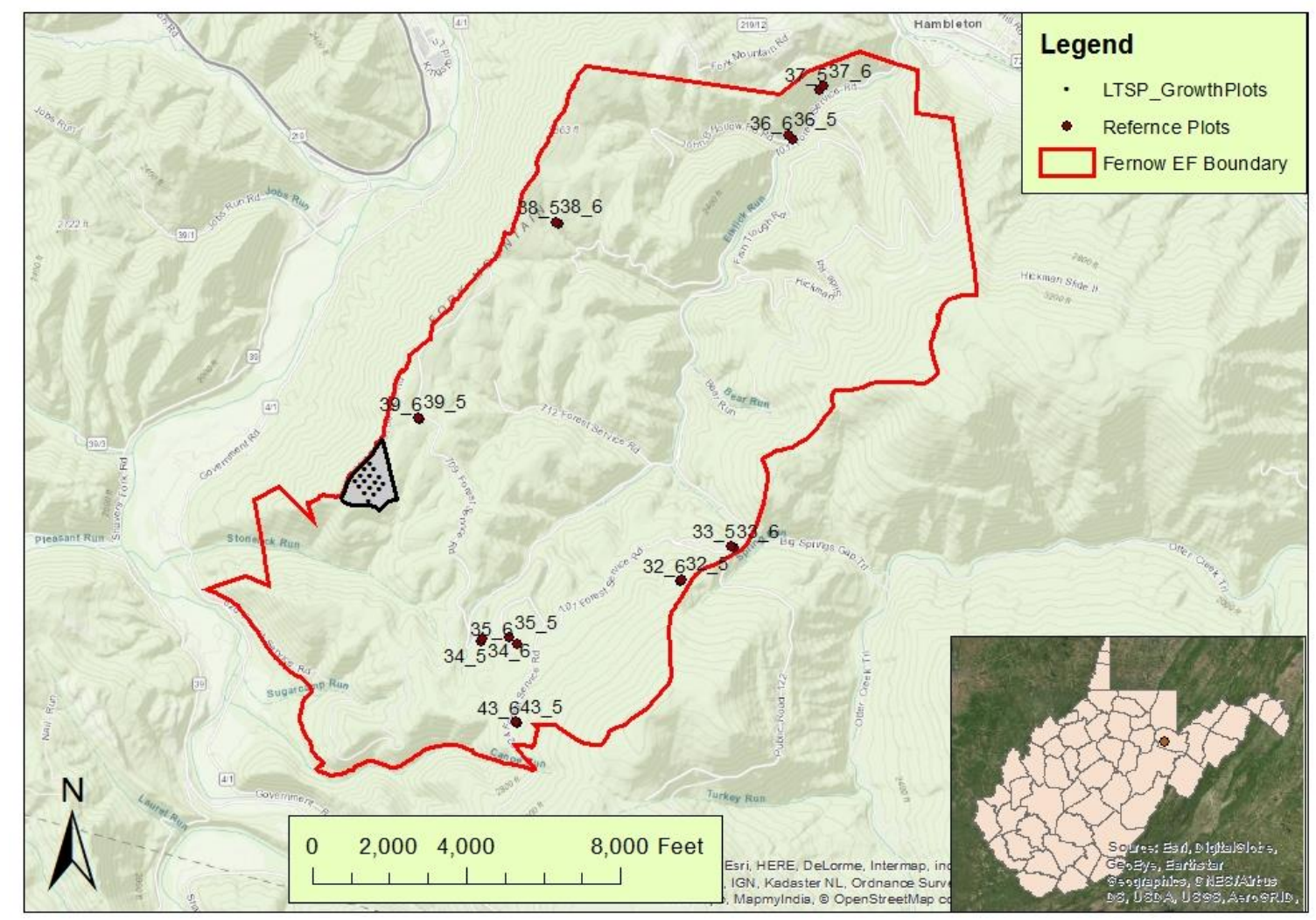

Figure 1. Map of calibration plots and LTSP plot locations within the Fernow Experimental Forest just outside Parsons in Tucker County, West Virginia. 
Table 1. Description of site features associated with the 18 calibration plots used for model calibration.

\begin{tabular}{cccccc}
\hline Stand & $\begin{array}{c}\text { Plot } \\
\text { No. }\end{array}$ & $\begin{array}{c}\text { Soil } \\
\text { Series }\end{array}$ & Aspect & $\begin{array}{c}\text { Elevation } \\
(\mathrm{ft})\end{array}$ & $\begin{array}{c}\text { Slope } \\
(\%)\end{array}$ \\
\hline 32 & 5 & Cateache & N & 2933 & 15 \\
32 & 6 & Cateache & NW & 2949 & 15 \\
33 & 5 & Belmont & N & 2562 & 55 \\
33 & 6 & Belmont & N & 2572 & 55 \\
34 & 5 & Calvin & NW & 2533 & 30 \\
34 & 6 & Calvin & NW & 2549 & 30 \\
35 & 5 & Calvin & SW & 2625 & 55 \\
35 & 6 & Dekalb & SW & 2674 & 55 \\
36 & 5 & Calvin & SE & 1969 & 45 \\
36 & 6 & Calvin & SE & 1880 & 45 \\
37 & 5 & Calvin & SE & 1913 & 55 \\
37 & 6 & Calvin & SE & 1939 & 55 \\
38 & 5 & Calvin & SW & 2539 & 35 \\
38 & 6 & Calvin & SW & 2546 & 35 \\
39 & 5 & Dekalb & SE & 2743 & 5 \\
39 & 6 & Dekalb & SE & 2743 & 5 \\
43 & 5 & Belmont & NW & 2808 & 20 \\
43 & 6 & Belmont & NW & 2831 & 20 \\
\hline
\end{tabular}

\section{$\underline{\text { LTSP Site }}$}

The Fork Mountain Long-Term Soil Productivity site (LTSP) was established within the Fernow Experimental Forest near Parsons, WV in 1996 as a part of a nation-wide effort to quantify anthropogenic influences on forest soils. The main goal of the Fork Mountain LTSP study was to characterize the effects acid deposition and whole tree harvesting methods on central Appalachian forest soils and vegetation. At that point in time, there were uncertainties on the degree to which local, state and federal legislation could influence the amount of nitrogen and sulfur deposition in the central Appalachian region. In addition, there were concerns that intensive forest management practices (i.e. whole tree harvesting) could lead to reduced soil fertility. The combination of the treatments allow investigators the opportunity to better 
understand how the processes of base cation leaching, soil acidification, and nitrogen saturation effect central Appalachian hardwood forests.

The Fork Mountain LTSP site is approximately 30 acres with a predominant southeast aspect and slopes between 15 and 30 percent. The elevation of the site ranges from approximately 2600 to 2800 feet above sea level. At the initiation of the study the stand was 85 years old, the site index (base age 50) for red oak was 80, and it was classified as a central Appalachian mixed hardwood forest type. The soils on site are Calvin, Berks and Hazelton series and are derived from sandstone colluvium, sandstone residuum, and weathered shale (Adams et al., 2004).

\section{LTSP Treatment Description}

In order to determine the long-term effects of elevated rates of acidic deposition on forest productivity, four treatments were implemented on the site in a complete randomized block design (Figure 2). Each of the four blocks contains one replication of the four treatments. Blocks were arranged by slope position. Each treatment plot is made up of a 0.5 ac growth plot (150 ft x $150 \mathrm{ft}$ ) and a 25 foot untreated buffer strip surrounding the growth plot (Figure 3). Within each treatment plot a total of 40 permanent rods were installed in a systematic grid to monument the location of permanent subplots. 


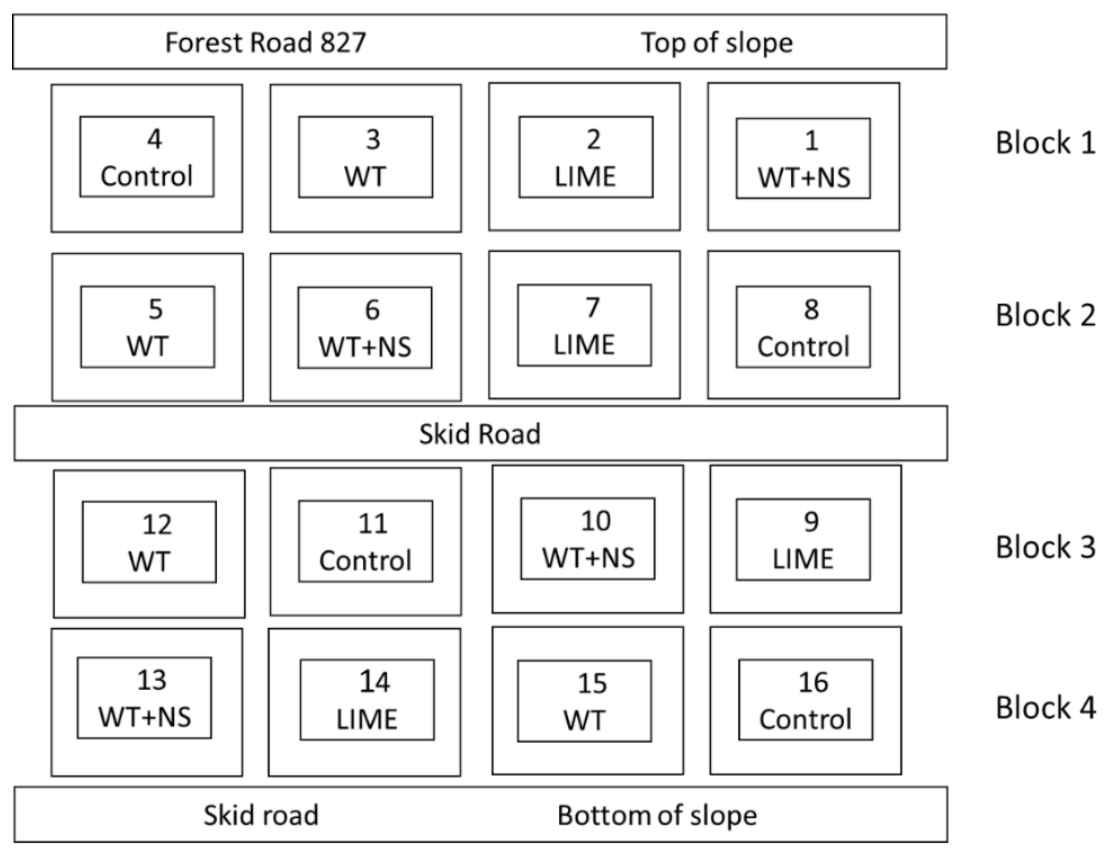

Figure 2. Physical layout of treatments of the Fork Mountain LTSP site. Figure modified from Adams et al., 2004.

Overstory Plots:

Small Circle $\left(\mathrm{DBH}<5^{\prime \prime}\right)=1 / 100^{\text {th }}$ acre

Large Circle $\left(\mathrm{DBH}>5^{\prime \prime}\right)=1 / 10^{\text {th }}$ acre
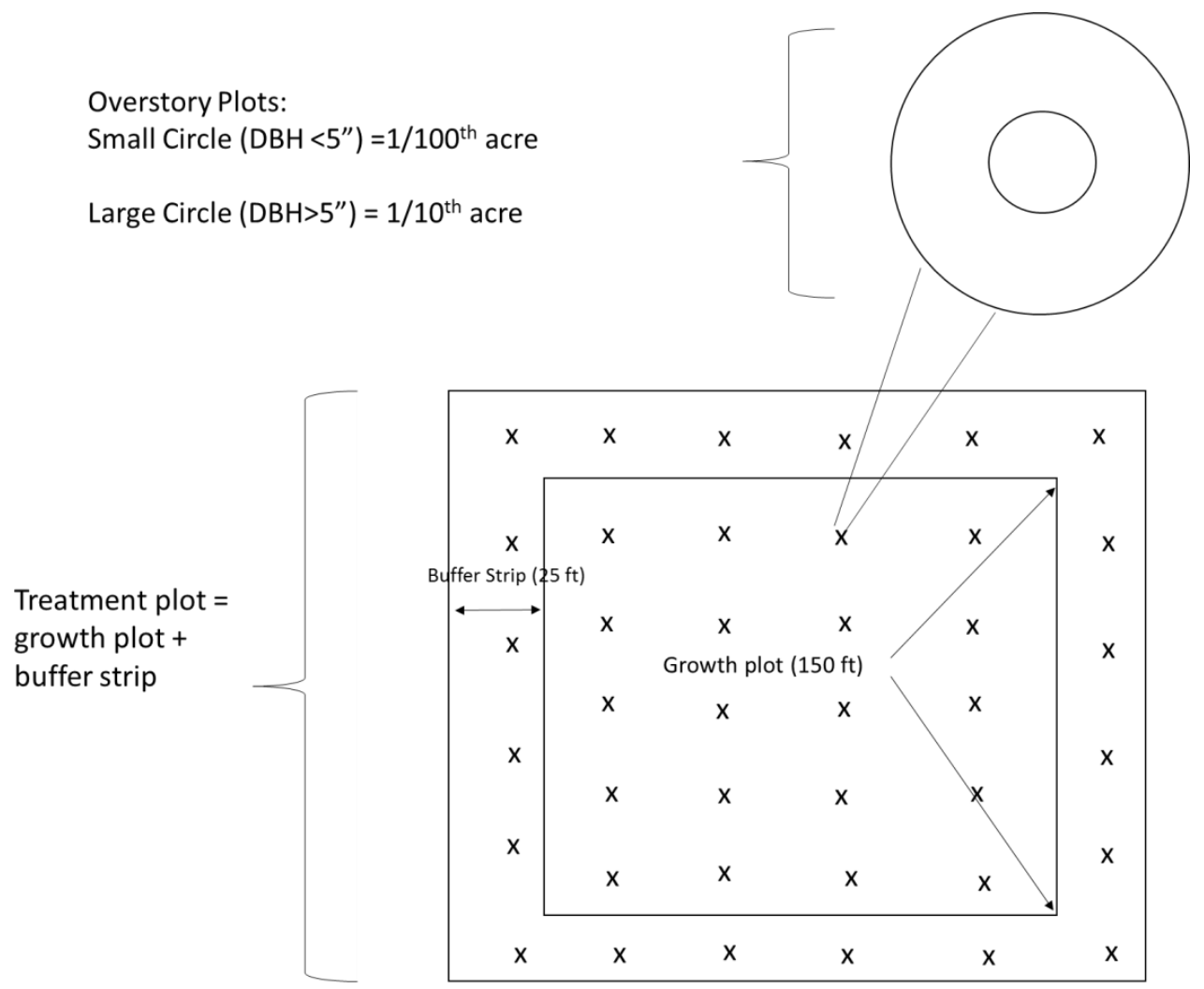

Figure 3. Layout of treatment plots of Fork Mountain LTSP. Permanent growth plots are indicated by X's as well as an example of the nested overstory plots. Figure modified from Adams et al., 2004. 
The treatments included: uncut control (CTRL), whole tree harvest (WT), whole tree harvest with the addition of ammonium sulfate fertilizer (WT+NS), and whole tree harvest + ammonium sulfate fertilizer + dolomitic lime addition (LIME). The ammonium sulfate was added at twice the ambient nitrogen (13.4 lb N/ac/yr) and sulfur (15.2 lb S/ac/yr) deposition rates. The dolomitic lime was added at twice the rate of calcium $(10.0 \mathrm{lb} \mathrm{Ca} / \mathrm{ac} / \mathrm{yr})$ and magnesium (5.2 lb Mg/ac/yr) export from a watershed in close proximity to the site (Adams et al., 2004). The dolomitic lime addition serves to mitigate the negative effects of soil acidification in order to better understand the effect of continual nitrogen addition the ecosystem. Soil amendments were applied to the designated growth plots three times per year to simulate natural deposition patterns. For the purposes of this study, only the WT, WT+NS, and LIME plots will be considered for analysis.

\section{Data Collection}

\section{Calibration Dataset}

Within each calibration stand there are two permanent 0.25 acre plots ( 18 in total) that have been periodically measured by US Forest Service personnel since the stands were approximately 20 years of age. All trees greater than 1 in dbh within the plots were tagged and dbh measurements recorded. Diameter data were available for each tree between the approximated ages of 20 and 50 as well as mortality over that time period.

\section{$\underline{\text { LTSP Dataset }}$}

A total of 60 randomly selected subplots were sampled within the LTSP site. Trees between $1-5$ inches at dbh were measured within 0.01 acre plots, while trees greater than 5 inches at dbh were measured inside 0.10 acre plots. I also measured total height on select dominant and codominant trees of the most common species on site. The number of height 
measurements varied by species, depending on the availability of codominant and dominant stems within the plots. In addition, quality and crown class were recorded for each tree.

\section{Model Calibration}

I utilized individual tree data over a 30 year period from 18 permanent plots on the Fernow Experimental Forest to calibrate FVS NE to local growing conditions. Initially I tested the base model performance against this dataset to determine if modifications were necessary. I used the measures of trees per acre (TPA) and basal area per acre (ba/ac) as the metrics for comparison between actual and predicted values. The evaluation of non-calibrated model projections indicated poor out-of-box performance. I determined that two parameters of greatest concern within the model for modification were the mortality function and large tree basal area growth function. A workflow for the calibration and validation of the FVS NE model to local growing conditions the FEF is provided below (Figure 4). 


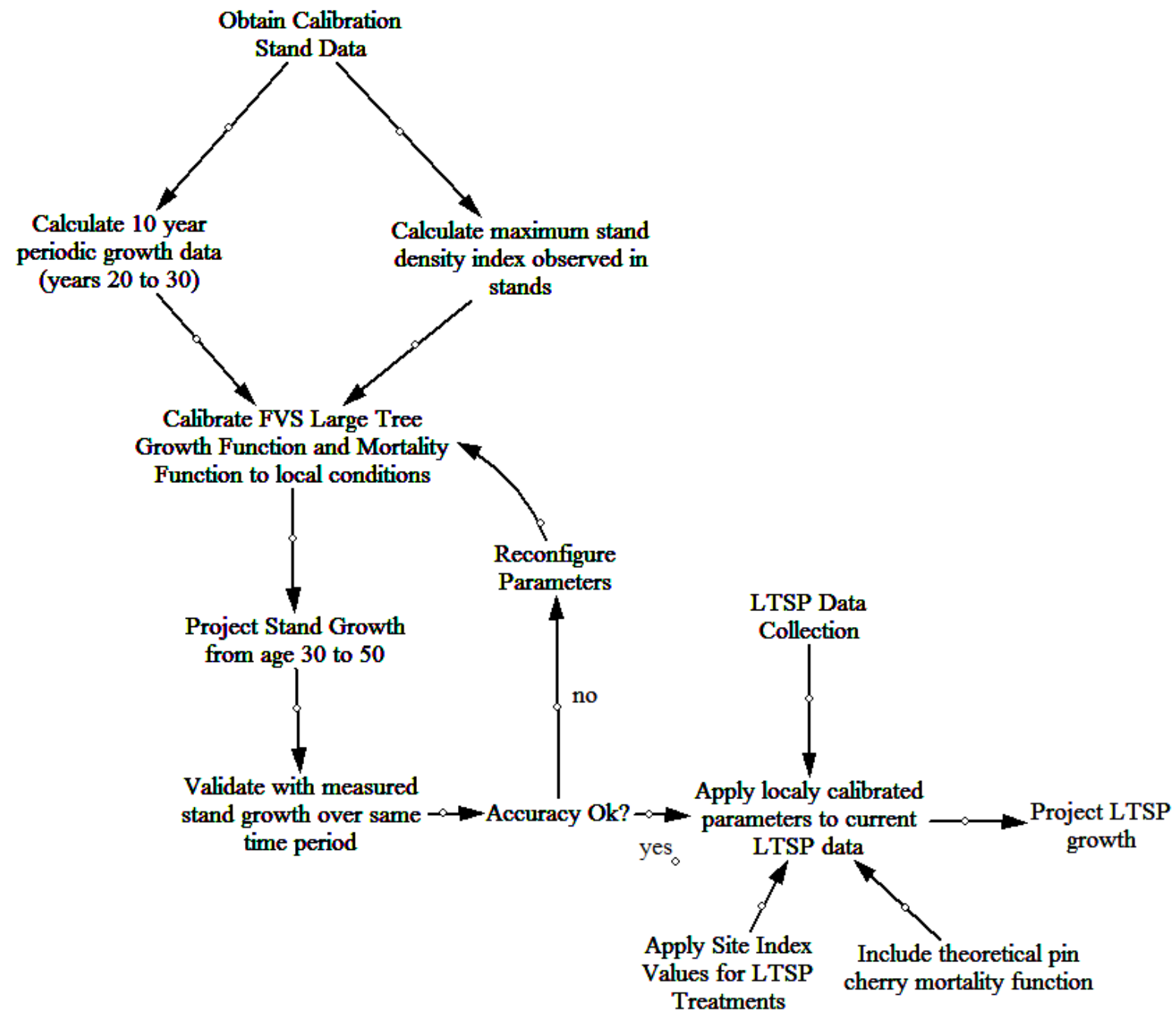

Figure 4. Workflow for calibration and validation of the northeast variant of the Forest Vegetation Simulator for the Fernow Experimental Forest.

Mortality in the FVS NE model is a function of the density at any given point in time. It uses a maximum stand density index (SDI) value and the percentages of the max SDI at which: 1) density-related mortality begins and 2) the stand reaches maximum density; to determine when background mortality should be applied to the trees. Maximum stand density index was determined based off calculated SDI values using the data available from the calibration stands across all time periods (ages $20-50$ ). Within the calibration stands a maximum observed SDI 
value of 318 was calculated and used for all future model simulations. I chose to keep the default percentages of $55 \%$ and $85 \%$ for the values of when density-related mortality begins, and when the stand reaches maximum density, respectively (Dixon \& Keyser, 2008).

To calibrate the large tree basal area growth function I utilized the growth data from the first 10 years of periodic measurements for the calibration data. Each live tree (at age 30) was assigned a 10 year incremental growth value, equivalent to the observed growth from age $20-$ 30. The "Growth" keyword was used to read the data into the model and projected the growth of individuals based on observed values. The "CalbStat" keyword was used to calculate the growth of each species relative to the base model predicted growth. Any species that grew at higher rates than what the FVS NE base model would have predicted, had their large tree basal area growth function modified in the final model to reflect the observed increased growth rates. The model was based on a 1 year time step and growth modifications were applied during every time step in the projection.

\section{$\underline{\text { Modifications made for LTSP projection }}$}

To account for differences in growth on the treatments of the LTSP plots I included treatment specific site index values into the model. Yellow-poplar was chosen as the species for this adjustment due to its high abundance and large number of dominant and codominant stems in the stand. Subsequently, it was the species that was most frequent in our sample of height measurements for dominant and codominant trees. Site index values were estimated from site index curves for the Appalachian mountain region (Beck, 1962). Site index (base age 50 years) values for the three treatments areas were calculated as 115 for WT plots and 110 for LIME and WT+NS plots. There was a consistent trend of higher site index values for the WT plots in comparison to the LIME and WT+NS for most species that had height measurements recorded. 
The projections for the WT+NS and LIME plots assumed that the response to the treatments was consistent across all time periods of the model projection.

I also included a second scenario (continual decline scenario) in the model for the fertilized plots, to describe a continued negative response of the overstory to the fertilizer treatments. On average, yellow-poplar trees in fertilized plots grew about 5 feet less in total height (after 20 years) compared to non-fertilized trees. If this negative trend were to occur for the remainder of the projection period, the dominant trees in the WT+NS and LIME plots would be another 10 feet shorter than the dominant non-fertilized trees. This height difference results in a site index at the end of the projection period (60 years) of 108 for the fertilized treatments (Beck, 1962). These continual decline scenario projections are designated in lowercase letters (wt+ns \& lime) in subsequent text.

One final adjustment made to the final model was to account for the natural dynamics of pin cherry (Prunus pensylvanica). There were very few pin cherries present on the calibration plots by the time the measurements began, so it was not reasonable to think the model would be able to predict the loss of pin cherry from the site based solely on the calibration data. A theoretical mortality function was included that would generally follow the dynamics described by Marks (1974). In the model, I assumed that pin cherry dominance has already begun its steep decline in persistence in the stand based on relative importance values calculated on the LTSP site in 2012 and 2017 (Table 1 in Chapter 2). Pin cherry tree mortality was modified in the model by removing $50 \%$ of each tree record for each time step until the species was no longer present in the overstory. Mortality was initially concentrated on smaller trees and secondarily on the larger trees. This instruction to the model assumes that the smaller pin cherry trees will be 
less competitive for light resources in the future and therefore die sooner than the larger trees that are receiving full light (Oliver \& Larson, 1996).

\section{Model Validation}

Model validation protocol generally follows framework developed by USFS FVS Steering Team (Cawrse et al., 2009). Variables predicted by the base model (ba/ac, TPA, QMD) were first verified by comparing general stand dynamic patterns. Base model performance was analyzed using mean percent error (MPE), root mean squared error (RMSE) and graphical representations of basal area and trees per acre changes over time. Locally calibrated values for maximum SDI and large tree basal area growth were included in the model. The observed vs. predicted TPA and ba/ac values for each calibration stand were again analyzed using MPE, RMSE and graphs. Once prediction error was reduced to less than 15\% MPE for both TPA and ba/ac (Russell et al., 2013), the modified model parameters were applied to LTSP plot data.

\section{$\underline{\text { Results: }}$}

\section{Model Calibration}

Overall the base model performed poorly in predictions of TPA and ba/ac. A consistent trend of higher TPA values and lower ba/ac values were predicted compared to field measurements (Figure 5). Across all stands and measurement periods, FVS NE over-predicted TPA values on average by approximately $33 \%$, with a maximum over prediction of $90 \%$. The mean percent error of TPA at the end of the 30 year projection period was $59 \%$ greater than measurements in the nine calibration stands. Average ba/ac projections were approximately $19 \%$ lower on average than observed values for all stands and time periods. 


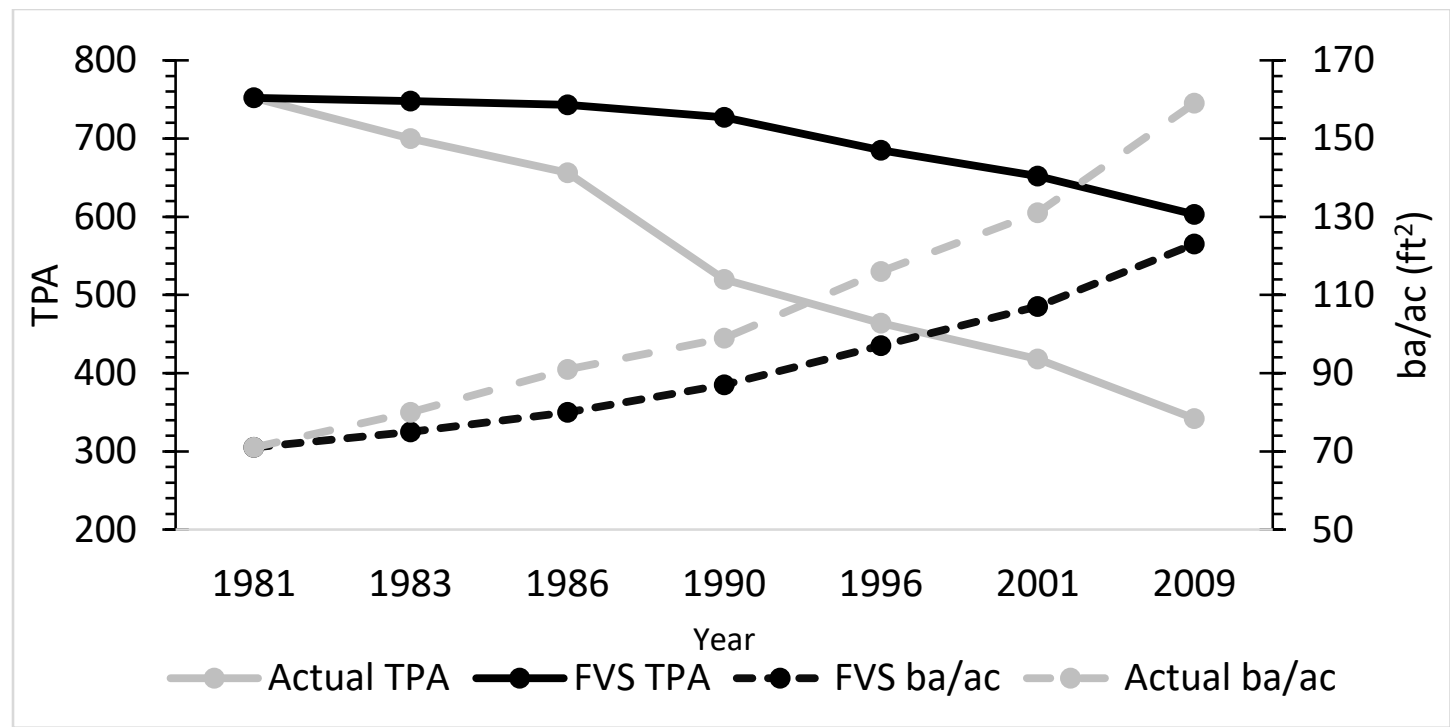

Figure 5. Base FVS Model performance plotted against actual growth data for calibration Stand 32. Model bias is consistent across all calibration stands. The remaining 8 calibration stand graphs of base model performance are included in Appendix A.

Results from the large tree basal area growth calibration revealed several species growing at higher rates on the FEF compared to base model predictions (Table 2). Increased growth rates were calculated for the following species: red maple (Acer rubrum) (13.2\%), sweet birch (41.8\%), yellow-poplar (14.2\%), black cherry (Prunus serotina) (21.5\%), chestnut oak (Quercus montana) (10.3\%), and red elm (Ulmus rubra) (4.8\%) (Table 2). For each species the large tree basal area growth parameter was modified to increase growth every time step with the multiplier provided below. 
Table 2. Species growing at higher rates in calibration plots than what is normally predicted by FVS NE. Species multiplier values here were used to modify the large tree basal area growth function. Species codes are as follows: RM (red maple), SB (sweet birch), YP (yellow-poplar), BC (black cherry), CO (chestnut oak), RL (red elm).

\begin{tabular}{l|rrrrr|rr}
\hline & \multicolumn{9}{c}{ Scale Factor Summary } & \multicolumn{3}{c}{ Total } \\
SPECIES & N & MIN & MEAN & MAX & \multicolumn{1}{c}{ DEV. } & \multicolumn{1}{r}{ RECORDS } & MULTIPLIER \\
\hline RM & 5 & 1.004 & 1.105 & 1.267 & 0.110 & 244 & 1.132 \\
SB & 7 & 1.160 & 1.383 & 1.893 & 0.241 & 164 & 1.418 \\
YP & 6 & 0.669 & 1.160 & 1.543 & 0.330 & 125 & 1.142 \\
BC & 5 & 0.996 & 1.345 & 1.975 & 0.420 & 138 & 1.215 \\
CO & 2 & 1.007 & 1.183 & 1.358 & 0.248 & 67 & 1.103 \\
RL & 2 & 0.816 & 1.008 & 1.200 & 0.272 & 31 & 1.048 \\
\hline
\end{tabular}

\section{Model Validation}

After the calibration of the max SDI and large tree basal area growth functions, the model was applied to the calibration stand data for year 30 and growth was predicted over the next 20 years. The predicted values for trees per acre and basal area per acre were similar to the observed values. On average the calibrated model reduced the systematic error in base model performance by $71 \%$ for MPE of TPA and $81 \%$ for MPE of ba/ac (Table 3). Average root mean square error values for TPA ranged between \pm 17 - 81 stems with an average RMSE of 43 trees per acre for all stands. Average trees per acre MPE for all stands was $\pm 7.7 \%$. Basal area per acre RMSE values ranged between $\pm 3-15 \mathrm{ft}^{2} \mathrm{ba} / \mathrm{ac}$ with an average value of approximately $\pm 8.1 \mathrm{ft}^{2} \mathrm{ba} / \mathrm{ac}$ difference. The overall average MPE of basal area per acre predictions was $\pm 3.5 \%$. Generally deviations from the observed values increased as the model progressed through time (Figure 6). 
Table 3. Mean percent error (MPE) and Root Mean Square Error (RMSE) values for trees per acre and basal area per acre $\left(\mathrm{ft}^{2} \mathrm{ba} / \mathrm{ac}\right)$ calculated by comparing FVS NE base model and FEF locally calibrated model predictions to observed values in nine calibration stands. Positive numbers represent an overestimation by the model and negative numbers represent underestimation.

\begin{tabular}{|c|c|c|c|c|c|c|c|c|}
\hline \multirow[b]{2}{*}{ Stand } & \multicolumn{4}{|c|}{ Base Model (30 years of Projections) } & \multicolumn{4}{|c|}{ FEF Calibrated Model (20 Years of Projections) } \\
\hline & $\begin{array}{l}\text { MPE } \\
\text { TPA }\end{array}$ & $\begin{array}{c}\text { MPE } \\
\text { BA }\end{array}$ & $\begin{array}{c}\text { RMSE } \\
\text { TPA }\end{array}$ & $\begin{array}{l}\text { RMSE } \\
\mathrm{Ba} / \mathrm{ac}\end{array}$ & $\begin{array}{l}\text { MPE } \\
\text { TPA }\end{array}$ & $\begin{array}{l}\mathrm{MPE} \\
\mathrm{Ba} / \mathrm{ac}\end{array}$ & $\begin{array}{l}\text { RMSE } \\
\text { TPA }\end{array}$ & $\begin{array}{l}\text { RMSE } \\
\mathrm{Ba} / \mathrm{ac}\end{array}$ \\
\hline 32 & $40 \%$ & $-15 \%$ & 193 & -21 & $-3 \%$ & $-1 \%$ & -17 & -9 \\
\hline 33 & $42 \%$ & $-13 \%$ & 177 & -18 & $5 \%$ & $-1 \%$ & -23 & -5 \\
\hline 34 & $49 \%$ & $-15 \%$ & 181 & -16 & $-4 \%$ & $8 \%$ & -37 & 11 \\
\hline 35 & $25 \%$ & $-18 \%$ & 124 & -22 & $-12 \%$ & $0 \%$ & -58 & -5 \\
\hline 36 & $16 \%$ & $-30 \%$ & 75 & -34 & $1 \%$ & $5 \%$ & 12 & 6 \\
\hline 37 & $48 \%$ & $-23 \%$ & 165 & -27 & $16 \%$ & $1 \%$ & 48 & 3 \\
\hline 38 & $21 \%$ & $-14 \%$ & 125 & -16 & $-12 \%$ & $-2 \%$ & -81 & -5 \\
\hline 39 & $50 \%$ & $-19 \%$ & 214 & -30 & $-9 \%$ & $-7 \%$ & -45 & -15 \\
\hline 43 & $16 \%$ & $-18 \%$ & 81 & -25 & $-12 \%$ & $-6 \%$ & -66 & -11 \\
\hline
\end{tabular}

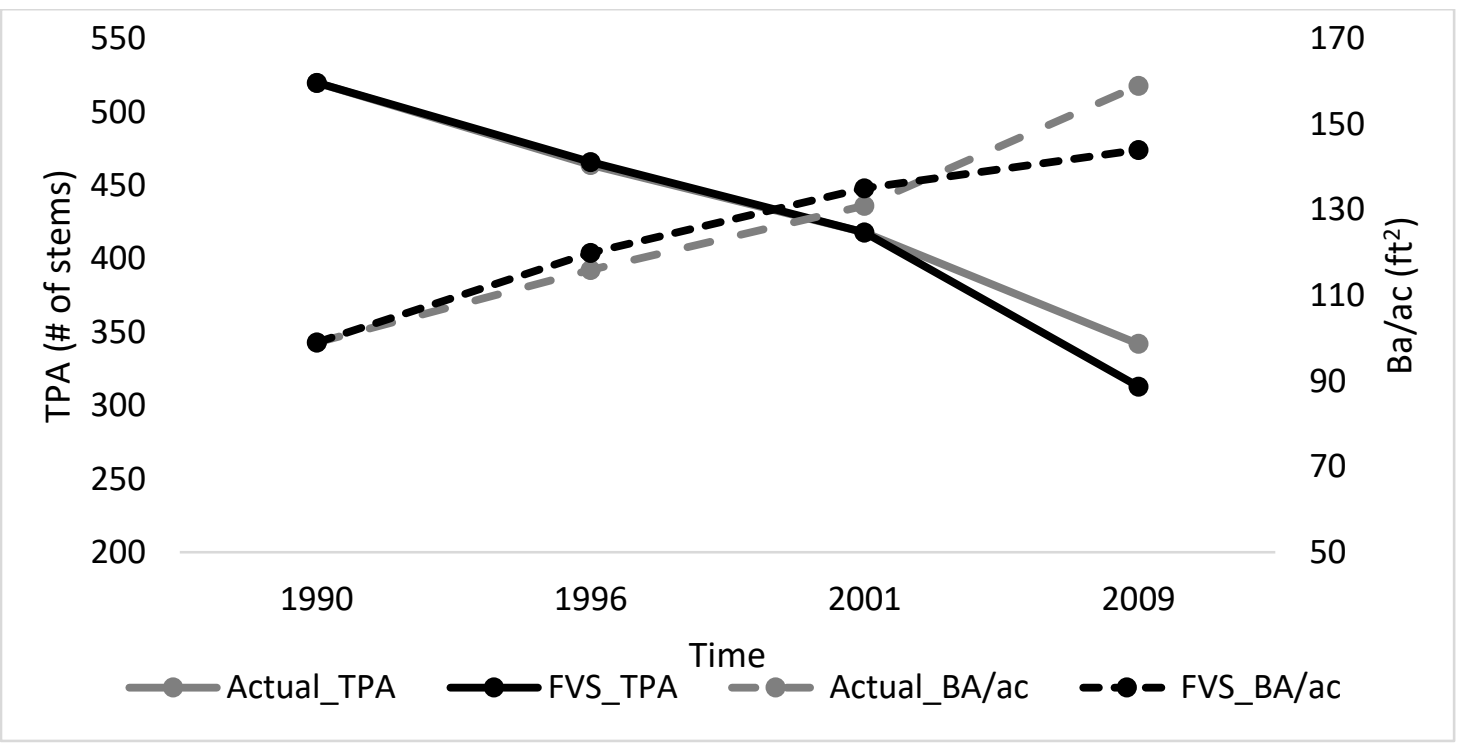

Figure 6. Locally Calibrated FVS Model performance plotted against actual growth data for calibration Stand 32. A visual representation of an example of the decrease in model systematic error after model calibration to local growing conditions (Compare to Figure 5). For visual representation of model performance of the other 8 stands see Appendix B. 


\section{Projection of LTSP Data}

The FEF calibrated model was applied to 21 year LTSP plot data to determine differences in volume produced within each treatment area. Projections indicate an initial, small decrease in volume on site for all treatments (Figure 7). This response is due to the mortality of pin cherry as it continues its natural life cycle (Figure 8A). The reduction in total volume is lesser for the WT plots due to the lower initial volume of pin cherry present in those areas. As the projection continues, there is little variation in the total merchantable volume of wood produced among treatments. Volumes at the end of the 40 year projection (61 year old stands) for WT plots was predicted to be the greatest $\left(5813 \mathrm{ft}^{3} / \mathrm{ac}\right)$ of the three, followed by the LIME plots $\left(5554 \mathrm{ft}^{3} / \mathrm{ac}\right)$ and the WT+NS $\left(5515 \mathrm{ft}^{3} / \mathrm{ac}\right)$.

For the continual decline scenario, the fertilized treatments resulted in negligible differences by the end of the projection. Final volumes projected for the wt+ns and lime plots were $5426 \mathrm{ft}^{3} / \mathrm{ac}$ and $5460 \mathrm{ft}^{3} / \mathrm{ac}$ respectively. Due to the near identical projections of the continual decline scenario to the scenario modelling the static response of the WT+NS and LIME treatments, no further results for the continual decline wt+ns and lime treatments are provided. 


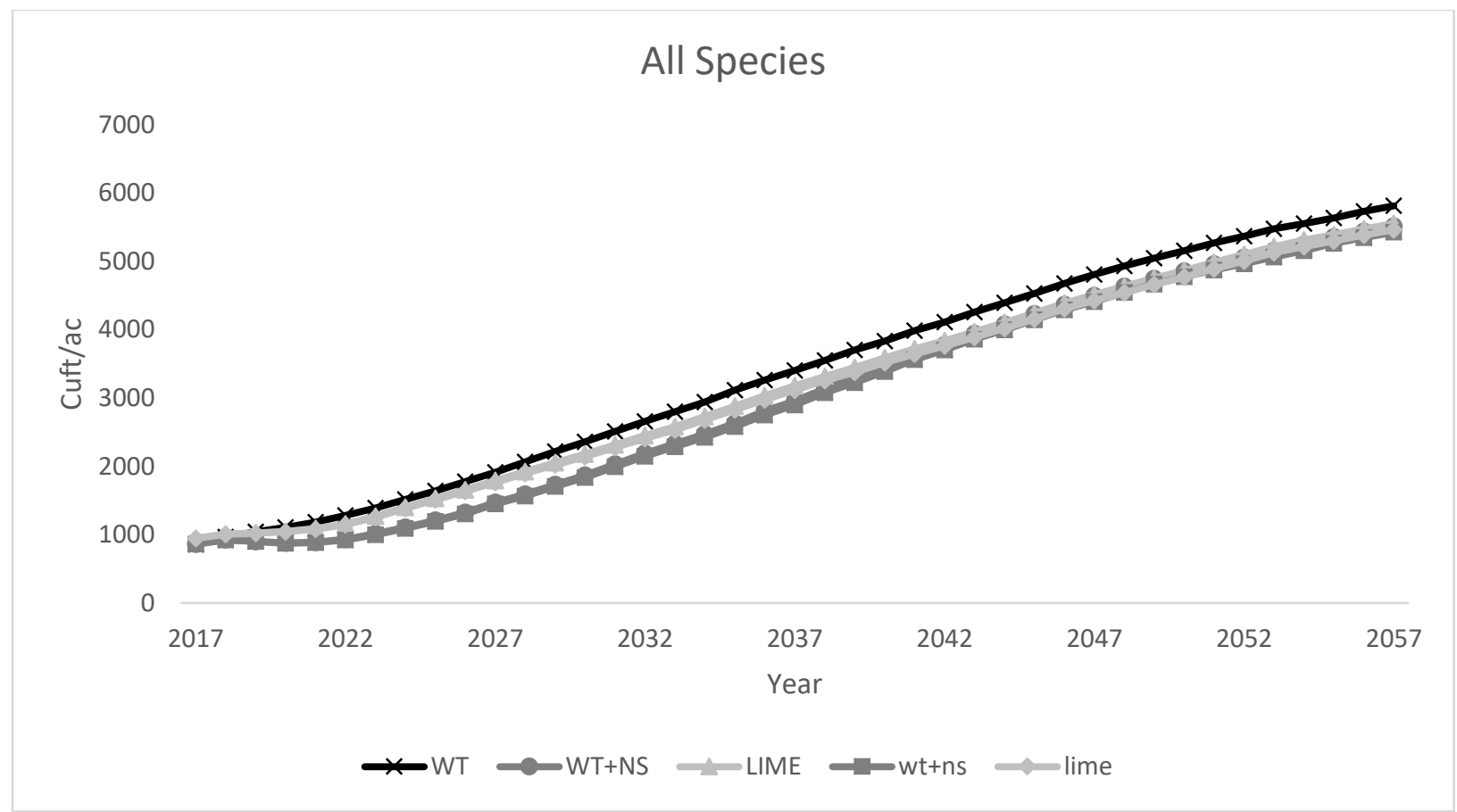

Figure 7. Model projections for average merchantable cubic feet per acre of all species by treatment, over time.

Yellow-poplar was projected to be the dominant species on the site throughout the next 40 years in terms of merchantable volume (Figure $8 \mathrm{~B}$ ) and is most likely the driving species behind the slightly higher total volume in the WT treatment areas. By the end of the projection period yellow-poplar made up almost $65 \%$ of the total volume on the WT plots and approximately $50 \%$ on both the WT+NS and LIME plots. At the start of the projection, yellowpoplar stems made up $38 \%$ of the trees on WT plots, but only $25 \%$ on the WT+NS plots and $21 \%$ on the LIME plots (Table 4). The greatest differences in TPA among treatments were for the smallest diameter class (Table 5). For example, yellow-poplar stems in the 2 inch diameter class are nearly three times more abundant on the WT plots than the WT+NS and LIME plots. 
Table 4. FVS NE predicted stocking of mean percentage of total trees per acre in each treatment area for 10 year projection intervals. Values of $0 \%$ represent less than $1 \%$ total trees per acre while dashes (-) represent species absence from the corresponding area.

\begin{tabular}{|c|c|c|c|c|c|c|c|c|c|c|c|c|c|c|c|}
\hline \multirow[b]{2}{*}{ Species } & \multicolumn{5}{|c|}{ WT } & \multicolumn{5}{|c|}{$\mathrm{WT}+\mathrm{NS}$} & \multicolumn{5}{|c|}{ LIME } \\
\hline & 2017 & 2027 & 2037 & 2047 & 2057 & 2017 & 2027 & 2037 & 2047 & 2057 & 2017 & 2027 & 2037 & 2047 & 2057 \\
\hline black cherry & $5 \%$ & $6 \%$ & $6 \%$ & $7 \%$ & $8 \%$ & $5 \%$ & $6 \%$ & $6 \%$ & $7 \%$ & $9 \%$ & $14 \%$ & $17 \%$ & $17 \%$ & $16 \%$ & $16 \%$ \\
\hline black locust & - & - & - & - & - & $0 \%$ & $0 \%$ & $0 \%$ & $0 \%$ & $0 \%$ & $1 \%$ & $1 \%$ & $0 \%$ & $0 \%$ & - \\
\hline cucumbertree & $3 \%$ & $3 \%$ & $4 \%$ & $4 \%$ & $5 \%$ & $3 \%$ & $4 \%$ & $3 \%$ & $3 \%$ & $4 \%$ & $3 \%$ & $3 \%$ & $4 \%$ & $6 \%$ & $8 \%$ \\
\hline eastern hemlock & - & - & - & - & - & - & - & - & - & - & $0 \%$ & $0 \%$ & $0 \%$ & $0 \%$ & $0 \%$ \\
\hline hickory spp. & $0 \%$ & $0 \%$ & $1 \%$ & $1 \%$ & $1 \%$ & $0 \%$ & $0 \%$ & $0 \%$ & $0 \%$ & $0 \%$ & $1 \%$ & $2 \%$ & $2 \%$ & $1 \%$ & $1 \%$ \\
\hline Fraser magnolia & $1 \%$ & $1 \%$ & $1 \%$ & $2 \%$ & $2 \%$ & $4 \%$ & $6 \%$ & $7 \%$ & $8 \%$ & $9 \%$ & $2 \%$ & $3 \%$ & $2 \%$ & $2 \%$ & $2 \%$ \\
\hline non-commercial & - & - & - & - & - & $3 \%$ & $3 \%$ & $2 \%$ & $1 \%$ & $0 \%$ & $2 \%$ & $2 \%$ & $2 \%$ & $1 \%$ & $0 \%$ \\
\hline pin cherry & $11 \%$ & $0 \%$ & - & - & - & $20 \%$ & $0 \%$ & - & - & - & $16 \%$ & $0 \%$ & - & - & - \\
\hline red maple & $7 \%$ & $9 \%$ & $12 \%$ & $16 \%$ & $20 \%$ & $6 \%$ & $8 \%$ & $10 \%$ & $12 \%$ & $15 \%$ & $12 \%$ & $16 \%$ & $17 \%$ & $22 \%$ & $25 \%$ \\
\hline red oak & $2 \%$ & $2 \%$ & $2 \%$ & $2 \%$ & $2 \%$ & $3 \%$ & $3 \%$ & $2 \%$ & $2 \%$ & $2 \%$ & $3 \%$ & $4 \%$ & $4 \%$ & $4 \%$ & $4 \%$ \\
\hline sweet birch & $26 \%$ & $28 \%$ & $25 \%$ & $17 \%$ & $10 \%$ & $24 \%$ & $30 \%$ & $28 \%$ & $23 \%$ & $17 \%$ & $11 \%$ & $13 \%$ & $11 \%$ & $7 \%$ & $2 \%$ \\
\hline sourwood & - & - & - & - & - & $2 \%$ & $2 \%$ & $3 \%$ & $4 \%$ & $5 \%$ & - & - & - & - & - \\
\hline serviceberry & - & - & - & - & - & $3 \%$ & $4 \%$ & $4 \%$ & $4 \%$ & $2 \%$ & $2 \%$ & $2 \%$ & $2 \%$ & $1 \%$ & $0 \%$ \\
\hline sugar maple & - & - & - & - & - & - & - & - & - & - & $3 \%$ & $4 \%$ & $4 \%$ & $5 \%$ & $6 \%$ \\
\hline sassafras & $1 \%$ & $1 \%$ & $1 \%$ & $0 \%$ & $0 \%$ & $1 \%$ & $2 \%$ & $2 \%$ & $2 \%$ & $1 \%$ & - & - & - & - & - \\
\hline striped maple & $5 \%$ & $7 \%$ & $9 \%$ & $12 \%$ & $13 \%$ & $1 \%$ & $1 \%$ & $2 \%$ & $2 \%$ & $2 \%$ & $6 \%$ & $7 \%$ & $9 \%$ & $11 \%$ & $12 \%$ \\
\hline white ash & $1 \%$ & $1 \%$ & $1 \%$ & $0 \%$ & $0 \%$ & - & - & - & - & - & $1 \%$ & $1 \%$ & $1 \%$ & $0 \%$ & $0 \%$ \\
\hline yellow-poplar & $38 \%$ & $41 \%$ & $38 \%$ & $39 \%$ & $39 \%$ & $25 \%$ & $31 \%$ & $31 \%$ & $31 \%$ & $33 \%$ & $21 \%$ & $24 \%$ & $23 \%$ & $24 \%$ & $24 \%$ \\
\hline
\end{tabular}




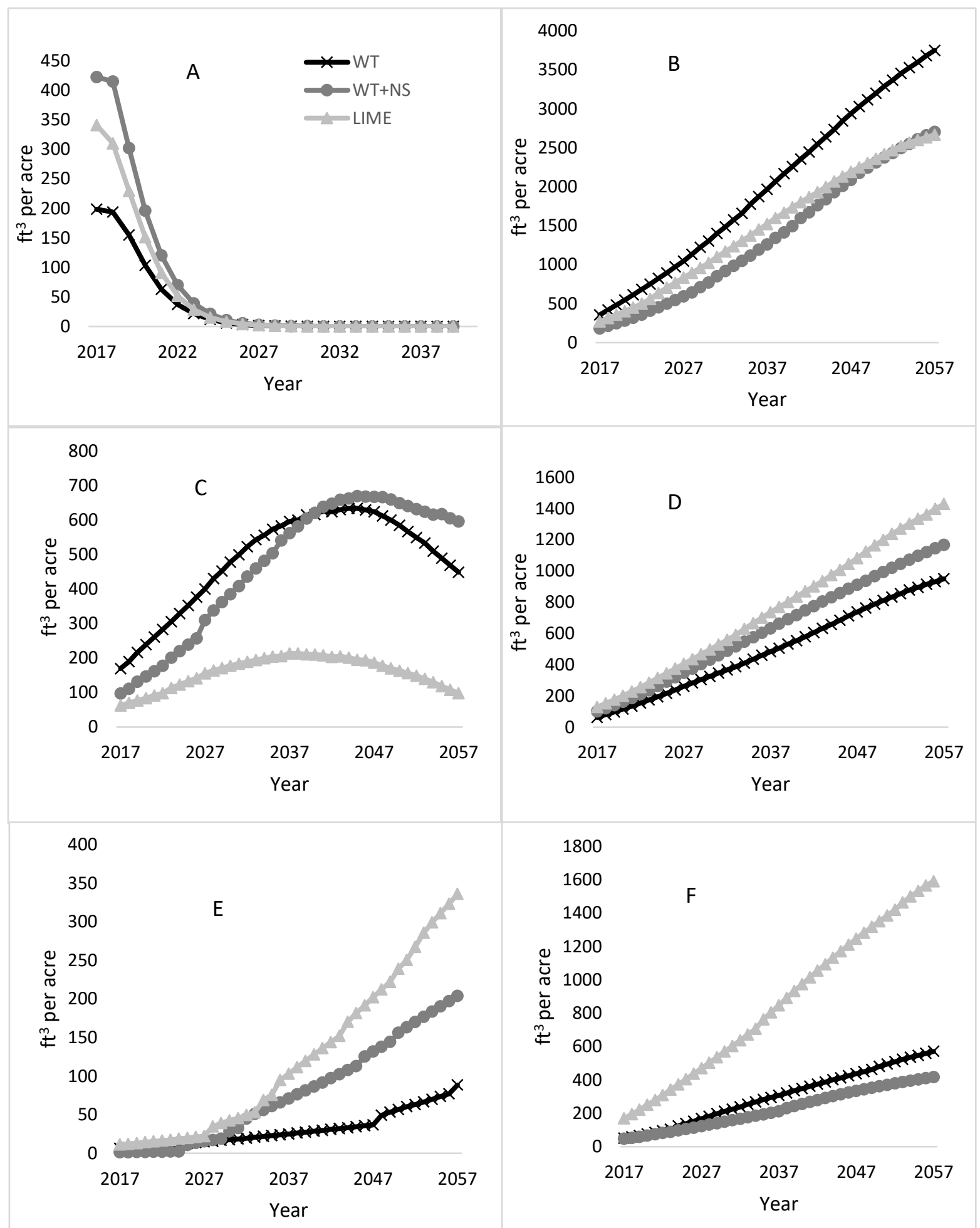

Figure 8. Species specific cumulative growth predictions for 3 treatments on the LTSP site. Six species (in order of highest - lowest RIV at year 2017) (Table 1 in Chapter 1) are presented and correspond to figures as follows: A) pin cherry, B) yellow-poplar, C) sweet birch, D) black cherry, E) red maple, F) cucumbertree. 
Table 5. Trees per acre for each species and diameter class for the Fork Mountain LTSP in year 2017.

\begin{tabular}{|c|c|c|c|c|c|c|c|c|c|c|c|c|c|c|c|c|}
\hline \multirow[b]{2}{*}{ Species } & \multicolumn{5}{|c|}{ WT } & \multicolumn{5}{|c|}{$\begin{array}{c}\text { WT+NS } \\
\text { Diameter Class (inches) }\end{array}$} & \multicolumn{6}{|c|}{ LIME } \\
\hline & 2 & 4 & 6 & 8 & 10 & 2 & 4 & 6 & 8 & 10 & 2 & 4 & 6 & 8 & 10 & 12 \\
\hline black cherry & 30 & 15 & 15 & 3 & - & 25 & 5 & 10 & 9 & 2 & 105 & 25 & 11 & 7 & 2 & 2 \\
\hline black locust & - & - & - & - & - & - & - & 1 & - & - & - & 5 & 2 & - & - & - \\
\hline cucumbertree & 20 & 10 & 3 & 4 & & 20 & 5 & 2 & 2 & 1 & 10 & 5 & 6 & 6 & 2 & \\
\hline eastern hemlock & - & - & - & - & - & - & - & - & - & - & - & - & 1 & - & - & - \\
\hline hickory & 5 & - & - & - & - & - & - & - & 1 & - & 10 & 5 & - & - & - & - \\
\hline Fraser magnolia & 5 & - & 4 & 2 & - & 25 & 15 & 3 & - & - & 5 & 10 & 7 & 4 & - & - \\
\hline non-commercial & - & - & - & - & - & 20 & 10 & - & - & - & 25 & - & - & - & - & - \\
\hline pin cherry & 25 & 50 & 60 & 12 & 1 & 25 & 60 & 90 & 27 & 5 & 15 & 65 & 69 & 23 & 4 & - \\
\hline red maple & 80 & 5 & 2 & - & - & 35 & 25 & 1 & - & - & 95 & 35 & 2 & - & 1 & - \\
\hline red oak & 25 & - & - & - & - & 20 & - & 1 & 1 & - & 20 & 15 & 2 & - & - & - \\
\hline sweet birch & 225 & 75 & 36 & 8 & - & 150 & 60 & 27 & 3 & - & 60 & 45 & 15 & 3 & - & - \\
\hline sourwood & - & - & - & - & - & 5 & 10 & 1 & - & - & - & - & - & - & - & - \\
\hline serviceberry & - & - & - & - & - & 30 & - & - & - & - & 20 & - & - & - & - & - \\
\hline sugar maple & - & - & - & - & - & - & - & - & - & - & 35 & - & - & - & - & - \\
\hline sassafras & 5 & 5 & 1 & - & - & 5 & 10 & - & - & - & - & - & - & - & - & - \\
\hline striped maple & 70 & - & - & - & - & 10 & - & 1 & - & - & 45 & 15 & - & - & - & - \\
\hline white ash & 10 & 5 & - & - & - & - & - & - & - & - & 15 & - & - & - & - & - \\
\hline yellow-poplar & 365 & 75 & 25 & 15 & 8 & 135 & 90 & 18 & 8 & 4 & 130 & 50 & 24 & 12 & 5 & 1 \\
\hline Total & 865 & 240 & 144 & 43 & 9 & 505 & 290 & 152 & 49 & 11 & 590 & 275 & 136 & 54 & 12 & 3 \\
\hline
\end{tabular}


Final volume differences by treatment for black cherry correspond with an initial higher percent trees per acre in the LIME treatment (Table 4). Initially black cherry stems were nearly three times more abundant on LIME plots than on the WT and WT+NS plots. In addition, there were no black cherry trees on the WT plots greater than the 8 -inch diameter class (Table 5). By the end of the projection, black cherry merchantable volume on the LIME plots was $479 \mathrm{ft}^{3} / \mathrm{ac}$ more than the WT plots and $261 \mathrm{ft}^{3} / \mathrm{ac}$ higher than the WT+NS plots (Figure 8D).

The growth of cucumbertree over time is projected to also follow a similar linear trend as black cherry and yellow-poplar. In contrast, there was no difference in the initial percent of the total trees per acre in the any of the treatment areas for cucumbertree (Table 4). However, there were a greater number of large individual trees that were measured on the LIME plots compared to trees growing in the WT and WT+NS plots (Table 5). The initial merchantable volume present on LIME plots was over three times greater than that on the other two treatments (Figure 8F). After 40 years of growth, cucumbertree is predicted to account for $1429 \mathrm{ft}^{3} / \mathrm{ac}$ on the LIME plots, $570 \mathrm{ft}^{3} / \mathrm{ac}$ on the WT plots and $417 \mathrm{ft}^{3} / \mathrm{ac}$ on the WT+NS plots.

Red maple projections deviated from the generally linear growth trends for yellowpoplar, black cherry and cucumbertree. Initially there were few red maple stems in the WT plots that were greater than 2 inches, which was not the case for the WT+NS and LIME plots (Table 5). Red maple stems were projected to represent little merchantable volume for the first decade of the projections in all of the treatments (Figure 8E). Around age 33 (year 2029) red maple stems receiving additional nitrogen from the treatments are expected to begin producing 
merchantable volume, culminating in $336 \mathrm{ft}^{3} / \mathrm{ac}$ on LIME plots and $204 \mathrm{ft}^{3} / \mathrm{ac}$ on WT+NS plots. The volume for red maple stems on WT plots was projected to be lower, only producing $88 \mathrm{ft}^{3} / \mathrm{ac}$ by age 61 (year 2057).

The total volume of sweet birch is projected to increase for all treatments until the trees are 40 - 50 (years 2037-2047) years old, after which mortality occurs in all treatments (Figure 8C). The LIME plots which started out with the lowest volume of sweet birch, also reach the point of maximum volume earliest. Between years 2038 and 2057 in the projection, the volume of sweet birch on LIME plots declined from $214 \mathrm{ft}^{3} / \mathrm{ac}$ to $98 \mathrm{ft}^{3} / \mathrm{ac}$. Both the WT and WT+NS plots reach their respective highest points of merchantable volume between the ages of 47 and 48 , respectively. The WT plots reach a maximum predicted value of $635 \mathrm{ft}^{3} / \mathrm{ac}$ and the WT+NS plots culminate at $670 \mathrm{ft}^{3} / \mathrm{ac}$. After this point, the mortality induced reduction in sweet birch volume on the WT plots was projected to decrease at a rate 2.5 times faster than the trees on the WT+NS plots.

\section{$\underline{\text { Discussion }}$}

The overall volume growth rate on the site is not projected to decline substantially over the 40 year projection for any treatment (Figure 7). However, it does seem that there will be major differences in the species that make up the final volume in the treatment areas (Table 4). This shift in species composition could have both economic and environmental implications in the future. Plots that received annual nitrogen additions were projected to grow less merchantable volume of yellow-poplar than the non-fertilized areas while the opposite may be true for red maple and black cherry. This growing space was utilized by other species such as black cherry, cucumbertree and red maple. By the end of the projection red maple made up an increasingly larger percentage of the number of trees in all of the treatment areas (Table 4). 
However the species only accounted for a small percent of total volume, suggesting many small red maple stems will persist in the midstory. This pattern of red maple growth dynamics is well documented (Lorimer, 1984; Oliver, 1978), however the model predictions suggest future volume increases for red maple grown in the fertilized areas compared to the non-fertilized areas (Figure 8E). Results from the model suggest that increased nitrogen could lead to further increases in red maple dominance in eastern hardwood forests, as suggested by others (Abrams, 1998).

The model predictions of volume growth over the 40 year period were similar to the species specific interactions with the treatments that have been observed for biomass accumulation on the site (Figure 6 in Chapter 1). Only sweet birch was predicted to deviate by the end of the projection from the original trends in volume ranking by treatment (Figure 8C). Mortality of sweet birch stems differs on the WT and WT+NS plots later in the projection. Initially, there were fewer stems in all of the diameter classes on the WT+NS compared to those sampled on WT plots (Table 5), so this response cannot be attributed to additional stems present in the larger diameter classes. It is likely that there was increased growing space in the WT+NS treated areas due the reduced volume of yellow-poplar as well as the loss of pin cherry. Since mortality in the model is based on the stand density index at any given point in time, there was less mortality assigned to sweet birch stems on the WT+NS plots compared to WT plots later in the projection due to relatively a relatively lower number of yellow-poplar stems in the WT+NS plots.

The initial growth responses of the individual tree species to the fertilizer were assumed to continue in the model for the duration of the projection. Thus the initial stand conditions were very influential in terms of the trajectory of growth projections for most of the major species in 
the model. In the case of yellow-poplar, which is projected to be the dominant merchantable species in all treatment areas (Figure 8B), the realized growth at the end of the projection period is highest in the WT plots. This difference can most likely be attributed to higher numbers of trees per acre in year 2017 (Table 5). Due to the fact that the model allocates background mortality as a percentage of all the individual trees (Dixon \& Keyser, 2008), there will be more yellow-poplar trees left at the end of the cycle in the WT plots than in the other treatments, all of which represent a value for merchantable volume.

This logic can also be used to explain the differences in growth of black cherry. Initially there were a greater number of trees per acre on the LIME plots (Table 5) which contributed to the increased growth predicted on the LIME plots throughout the projection (Figure 8D). Although the model predicts increases in growth on the LIME plots, there is little evidence in the literature to support the prediction. Mature black cherry trees have previously shown both short and long-term negative responses to single applications of dolomitic lime in areas of high historic acidic deposition (Long et al., 2011; Long et al., 1997). However, young black cherry trees have been shown to increase growth and foliar nutrient concentrations after nitrogen and phosphorus fertilizer (Auchmoody, 1982). Black cherry has also been shown to significantly increase basal area growth from one time fertilizer applications of N (Stanturf, 1989). It seems that black cherry responded positively to the first 21 years of the ammonium sulfate fertilizer on the FM LTSP (regardless of whether dolomitic lime was added) in terms of growing larger diameter individuals (Table 5), which resulted in increased final volume estimations for both fertilized treatment areas compared to the non-fertilized areas.

The site indexes (YP - 115 - WT plots, 100 - WT+NS and LIME, 108 - wt+ns and lime) for the model represent a negative response in growth from the chronic additions of $\mathrm{N}$. This 
response is corroborated with other reports of decreased growth of yellow-poplar from chronic additions of $\mathrm{N}$ on the FEF (DeWalle et al., 2006) but does not necessarily represent the response of all species to the treatments (Figure 6 in Chapter 2). The trend of increased height growth on the WT plots was consistent across many of the dominant species on site, but to varying degrees. The model could be limited in realizing the extent of the individual species response to additions of ammonium sulfate and lime for the species that have been shown to respond to the treatments differently. However, it would be difficult to characterize the species-specific responses to chronic additions of ammonium sulfate over a period of time that is similar to this projection due to a lack of empirical evidence.

There is a fertilizer treatment keyword ("FERTILIZ") in the Suppose interface (Dixon, 2002) that was developed from data in northern Idaho. Due to the origin of the model extension, I decided not to utilize this tool to attempt to predict the effects of ammonium sulfate on our mixed species eastern forest. The model extension does not allow for species specific responses to the fertilizer (Dyck \& Smith-Mateja, 2000), so again the model the model would be assuming that all species are responding to the treatment similarly, which is not the case on the FM LTSP (Figure 6 in Chapter 2). If it were possible to predict individual species growth rates due to fertilization in the model, the extension could be calibrated with local growth rates for fertilized trees and could be very useful in predicting growth for trees receiving chronic additions of ammonium sulfate.

The framework provided in this paper for model calibration and validation can be applied to other geographic areas where the FVS model is desired for use. Future work to provide growth rates that are representative for individual species across the central Appalachian Mountains is key for increasing the use of the model in this geographic region. The success of 
this study advocates for the both continuation of repeated measures of growth from established long-term studies and the initiation of new long-term studies. With an increased range of data for calibration I could have extended the projection of the LTSP data to represent the final volume to be expected after a full rotation of treatment.

In summary, I was successful in calibrating the FVS NE growth model to predict growth in a central Appalachian Forest. I identified species on the Fernow Experimental Forest that have been observed to grow at higher rates than what the model would have otherwise predicted. These growth rates were applied to the Fork Mountain LTSP data that was collected at age 21 and the model produced an output that expressed the growth of the most important species throughout the next 40 years of the stand's development. The treatment response in terms of final volumes of merchantable volume predicted by the model generally corroborate with the observed differences of biomass for each species and treatment in year 21 on the FM LTSP site. 


\section{Literature Cited:}

Aber, J. D., McDowell, W., Nadelhoffer, K., Magill, A., Berntson, G., Kamakea, M., ... Fernandez, I. (1998). Nitrogen saturation in temperate forest ecosystems - Hypotheses revisited. Bioscience, 48(11), 921-934.

Aber, J. D., \& Melillo, J. M. (1982). FORTNITE: a computer model of organic matter and nitrogen dynamics in forest ecosystems. Madison, WI: University of Wisconsin Research Bulletin R130.

Aber, J. D., Nadelhoffer, K. J., Steudler, P., \& Melillo, J. M. (1989). Nitrogen Saturation in Northern Forest Ecosystems. BioScience, 39(6), 378-386.

Abrams, M. D. (1998). The red maple paradox. BioScience, 48(May), 355-364.

Adams, M. B., Burger, J. A., Jenkins, A. B., \& Zelazny, L. (2000). Impact of harvesting and atmospheric pollution on nutrient depletion of eastern US hardwood forests. Forest Ecology and Management, 138(1-3), 301-319.

Adams, M. B., Burger, J., Zelazny, L., \& Baumgras, J. (2004). Description of the Fork Mountain Long-Term Soil Productivity Study: Site characterization, 43.

Adams, M. B., Kochenderfer, J. N., \& Edwards, P. J. (2007). The Fernow watershed acidification study: Ecosystem acidification, nitrogen saturation and base cation leaching. Water, Air, \& Soil Pollution, 7, 267-273.

Auchmoody, L. R. (1982). Response of young black cherry stands to fertilization. Canadian Journal of Forest Research, 12(2), 319-325.

Beck, D. E. (1962). Yellow-poplar Site Index Curves. Res. Note SE-180. Asheville, NC: US Department of Agriculture, Forest Service, Southeastern Experiment Station., 180, 2.

Botkin, D. B., Janak, J. F., \& Wallis, J. R. (1972). Some Ecological Consequences of a Computer Model of Forest Growth. Journal of Ecology, 60(3), 849-872.

Brand, G. J., \& Holdaway, M. R. (1989). Assessing the accuracy of TWIGS and STEMS85 volume predictions: a new approach. Northern Journal of Applied Forestry, 6(3), 109-114.

Brooks, J. R., \& Miller, G. W. (2011). An Evaluation of Three Growth and Yield Simulators for Even-Aged Hardwood Forests of the Mid-Appalachian Region. GTR-NRS-P-78, Proceedings of the 17th Central Hardwood Forest Conference, 23-32.

Burnham, M. B., Cumming, J. R., Adams, M. B., \& Peterjohn, W. T. (2017). Soluble soil aluminum alters the relative uptake of mineral nitrogen forms by six mature temperate broadleaf tree species: possible implications for watershed nitrate retention. Oecologia, 185(3), 327-337.

Canavan, S. J., \& Ramm, C. W. (2000). Accuracy and Precision of 10 Year Predictions for Forest Vegetation Simulator-Lake States. Northern Journal of Applied Forestry, 17(2), 6270.

Cawrse, D., Keyser, C., Keyser, T., Sanchez, A., Smith-Mateja, E., \& Van Dyck, M. (2009). Forest Vegetation Simulator Model Validation Protocols. Fort Collins, CO: USDA - Forest 
Service, Forest Management Service Center, (January), 1-10.

Christensen, N. L., \& Peet, R. K. (1984). Convergence During Secondary Forest Succession Author ( $\mathrm{s}$ ): Journal of Ecology, 72(1), 25-36.

Clements, F. E. (1916). Plant Succession: An Analysis of the Development of Vegetation. Carnegie Institution of Washington.

Coates, K. D., Canham, C. D., Beaudet, M., Sachs, D. L., \& Messier, C. (2003). Use of a spatially explicit individual-tree model (SORTIE/BC) to explore the implications of patchiness in structurally complex forests. Forest Ecology and Management, 186, 297-310.

Cronan, C. S., \& Grigal, D. F. (2004). Use of Cacium/Aluminum Ratios as Indicators of Stress in Forest Ecosytems. Environmental Quality, 24(2), 209-226.

Crookston, N. L. (1997). Suppose: An interface to the Forest Vegetation Simulator. Proceedings of Forest Vegetation Simulator Conference, (USDA Forest Service, Intermountain Research Station), 7-14.

Crookston, N. L., \& Dixon, G. E. (2005). The forest vegetation simulator: A review of its structure, content, and applications. Computers and Electronics in Agriculture, 49(1), 6080.

DeWalle, D. R., Kochenderfer, J. N., Adams, M. B., Miller, G. W., Gilliam, F. S., Wood, F., ... Sharpe, W. E. (2006). Vegetation and acidification. In M. B. Adams, J. N. Kochenderfer, \& J. L. Hom (Eds.), The Fernow watershed acidification study (pp. 137-188).

Dixon, G. E. (2002). Essential FVS: A user's guide to the Forest Vegetation Simulator. Fort Collins, CO: USDA - Forest Service, Forest Management Service Center, 212.

Dixon, G. E., \& Keyser, C. E. (2008). Northeast ( NE ) Variant Overview. Fort Collins, CO: USDA - Forest Service, Forest Management Service Center, (April), 1-61.

Driscoll, C. T., Lawrence, G. B., Bulger, A. J., Butler, T. J., Cronan, C. S., Eagar, C., Weathers, K. C. (2001). Acidic deposition in the northeastern United States: Sources and inputs, ecosystem effects, and management strategies. BioScience, 51(3), 180-198.

Dyck, M. G. Van, \& Smith-Mateja, E. E. (2000). Keyword Reference Guide for the Forest Vegetation Simulator Compiled by. Fort Collins, CO: USDA - Forest Service, Forest Management Service Center, 1-120.

Egler, F. E. (1954). Vegetation science concepts I. Initial floristic composition, A factor in oldfield vegetation development. Vegetation, 4(6), 412-417.

Fowler, Z. K., Adams, M. B., \& Peterjohn, W. T. (2015). Will more nitrogen enhance carbon storage in young forest stands in central Appalachia? Forest Ecology and Management, $337,144-152$.

Foy, C. D. (1984). Physiological Effects of Hydrogen, Aluminum, and Manganese Toxicities in Acid Soil. Soil Acidity and Liming, 57-97.

Foy, C. D., Chaney, R. L., \& White, M. C. (1978). The Pysiology of Metal Toxicity in Plants. Annual Review of Plant Physiology, 29, 511-566. 
Galloway, J. N., Likens, G. E., \& Edgerton, E. S. (1976). Acid precipitation in the Northeastern United States: $\mathrm{pH}$ and acidity. Science, 194, 722-724.

Hibbs, D. E. (1983). Forty Years of Forest Succession in Central New England. Ecology, 64(6), 1394-1401. https://doi.org/10.2307/1937493

Johnson, A. H. (1983). Red spruce decline in the northeastern u.s.: hypotheses regarding the role of acid rain. Journal of the Air Pollution Control Association, 33(11), 1049-1054.

Johnson, A. H., \& Siccama, T. G. (1983). Acid deposition and forest decline. Environmental Science and Technology, 17(7), 294-305.

Kowalski, D. G., \& Gertner, G. Z. (1989). A Validation of TWIGS for Illinois Forests. Northern Journal of Applied Forestry, 6, 154-156.

Lacerte, V., Larocque, G. R., Woods, M., Parton, W. J., \& Penner, M. (2004). Testing the Lake States variant of FVS (Forest Vegetation Simulator) for the main forest types of northern Ontario. The Forestry Chronicle, 80(4), 495-506.

Lacerte, V., Larocque, G. R., Woods, M., Parton, W. J., \& Penner, M. (2006). Calibration of the forest vegetation simulator (FVS) model for the main forest species of Ontario, Canada. Ecological Modelling, 199(3), 336-349.

Larocque, G. R., Shugart, H. H., Xi, W., \& Holm, J. A. (2016). Chapter 7: Forest Succession Models.

Leemans, R., \& Prentice, C. I. (1987). Description and simulation of tree layer composition and size distributions in a primaeval Picea-Pinus primaeval forest. Vegetation, 69(1), 147-156.

Leites, L. P., Robinson, A. P., \& Crookston, N. L. (2009). Accuracy and equivalence testing of crown ratio models and assessment of their impact on diameter growth and basal area increment predictions of two variants of the Forest Vegetation Simulator. Canadian Journal of Forest Research, 39(3), 655-665.

Liu, J., \& Ashton, P. S. (1995). Individual based simulation models for forest succession and management. Forest Ecology and Management, 73, 157-175.

Long, R. P., Horsley, S. B., \& Hall, T. J. (2011). Long-term impact of liming on growth and vigor of northern hardwoods. Canadian Journal of Forest Research, 41(6), 1295-1307.

Long, R. P., Horsley, S. B., \& Lilja, P. R. (1997). Impact of forest liming on growth and crown vigor of sugar maple and associated hardwoods. Canadian Journal of Forest Research, 27(10), 1560-1573.

Lorimer, C. G. (1984). Development of the red maple understory in northeastern oak forests. Forest Science, 30(1), 3-22.

Magill, A. H., Aber, J. D., Currie, W. S., Nadelhoffer, K. J., Martin, M. E., McDowell, W. H., ... Steudler, P. (2004). Ecosystem response to 15 years of chronic nitrogen additions at the Harvard Forest LTER, Massachusetts, USA. Forest Ecology and Management, 196, 7-28.

Marks, P. L. (1974). The Role of Pin Cherry ( Prunus pensylvanica L .) in the Maintenance of Stability in Northern Hardwood Ecosystems. Ecological Monographs, 44(1), 73-88. 
May, J. D., Burdette, S. B., Gilliam, F. S., \& Adams, M. B. (2005). Interspecific divergence in foliar nutrient dynamics and stem growth in a temperate forest in response to chronic nitrogen inputs. Canadian Journal of Forest Research, 35(5), 1023-1030.

McNulty, A. S. G., Aber, J. D., \& Boone, R. D. (1991). Spatial Changes in Forest Floor and Foliar Chemistry of Spruce-Fir Forests across New England. Biogeochemistry, 14(1), 1329.

Mladenhoff, D. J. (1993). LANDIS: a model of forest landscape succession and management at multiple scales. Proceedings of the Annual US Landscape Ecology Symposium. Oak Ridge, TN, USA, 77.

Mladenoff, D. J. (2004). LANDIS and forest landscape models. Ecological Modelling, 180(1), $7-19$.

Oliver, C. D. (1978). The development of northern red oak in mixed stands in central New England. Yale School of Forestry and Environmental Studies Bulletin, 91, 63.

Oliver, C. D., \& Larson, B. C. (1996). Forest Stand Dynamics: Updated Edition. New York: John Wiley \& Sons, Inc.

Pacala, S. W., Canham, C. D., Silandcer Jr., J. A., Kobe, R. K., \& Ribbens, E. (1996). Forest models defined by field measurements: estimation, error analysis and dynamics. Ecological Monographs, 66(1), 1-43.

Pacala, S. W., Canham, C. D., \& Silander Jr., J. A. (1993). Forest models defined by field measurements: The disign of the northeastern forest simulator. Canadian Journal of Forest Research, 23(10), 1980-1988.

Peterjohn, W. T., Adams, M. B., \& Gilliam, F. S. (1996). Symptoms of Nitrogen Saturation in Two Central Appalachian Hardwood Forest Ecosystems. Biogeochemistry, 35(3), 507-522.

Pickett, S. T. A., Collins, S. L., \& Armesto, J. J. (1987). Models, mechanisms and pathways of succession. The Botanical Review, 53(3), 335-371.

Pregitzer, K. S., Burton, A. J., Zak, D. R., \& Talhelm, A. F. (2008). Simulated chronic nitrogen deposition increases carbon storage in Northern Temperate forests. Global Change Biology, 14(1), 142-153.

Radtke, P. J., Herring, N. D., Loftis, D. L., \& Keyser, C. E. (2012). Evaluating Forest Vegetation Simulator Predictions for Southern Appalachian Upland Hardwoods with a Modified Mortality Model. Southern Journal of Applied Forestry, 36(2), 61-70.

Rauscher, H. M., Young, M. J., Webb, C. D., \& Robison, D. J. (2000). Testing the Accuracy of Growth and Yield Models for Southern Hardwood Forests. South. J. Appl. For., 24(3), 176185.

Richter, D. D., Johnson, D. W., \& Dai, K. H. (1991). Cation exchange and Al mobilization in soils. In D. W. Johnson \& S. E. Lindberg (Eds.), Atmospheric deposition and forest nutrient cycling (Vol. 91, pp. 341-377). Springer-Verlag, New York, New York, USA.

Russell, M. B., Weiskittel, A. R., \& A., K. J. J. (2013). Benchmarking and Calibration of Forest 
Vegetation Simulator Individual Tree Attribute Predictions Across the Northeastern United States. Northern Journal of Applied Forestry, 30(2), 75-84.

Schlesinger, W. H., \& Bernhardt, E. S. (2013). Biogeochemistry: An Analysis of Global Change (Third Edit). Elsevier.

Schuler, T. M., Marquis, D. A., Ernst, R. L., \& Simpson, B. T. (1993). Test of four stand growth simulators for the northeastern United States., Res. Pap.(June), 14p.

Shugart, H. H. (1984). A theory of forest dynamics. The ecological implications of forest successional models. New York: Springer-Verlag.

Shugart, H. H., Hopkins, M. S., Burgess, I. P., \& Mortlock, A. T. (1980). The development of a succession model for subtropical rain forest and its application to assess the effects of timber harvest at Wiangaree State Forest, New South Wales. Journal of Environmental Management, 11(3), 243-265.

Shugart, H. H., \& West, D. C. (1977). Development of an appalachian deciduous forest succession model and its application to assessment of the impact of the chestnut blight. Journal of Environmental Management, 5, 161-179.

Spiro, T. G., \& Stigliani, W. M. (2003). Chemistry of the Environment (2nd ed.). Prentice Hall.

Sprugel, D. G., Rascher, K. G., Gersonde, R., Dovčiak, M., Lutz, J. A., \& Halpern, C. B. (2009). Spatially explicit modeling of overstory manipulations in young forests: Effects on stand structure and light. Ecological Modelling, 220(24), 3565-3575.

Staff, S. S., Service, N. R. C., \& Agriculture, U. S. D. of. (n.d.). Official Soil Series Descriptions. Retrieved August 3, 2018, from https://soilseries.sc.egov.usda.gov/\#

Stage, A. R. (1973). Prognosis model for stand development. US Forest Service Research Paper INT-137, 32.

Stanturf, J. A. (1989). Effects of added nitrogen on growth of hardwood trees in southern New York. Canadian Journal of Forest Research, 19(2), 279-284.

Steudler, P. A., Bowden, R. D., Melillo, J. M., \& Aber, J. D. (1989). Influence of nitrogen fertilization on methane uptake in temperate forest soils. Nature, 341(6240), 314-316.

Taylor, A. R., Chen, H. Y. H., \& VanDamme, L. (2009). A review of forest succession models and their suitability for forest management planning. Forest Science, 55(1), 23-36.

Ulrich, B. (1982). Dangers for the Forest Ecosystem Due to Acid Precipitation. Necessary Countermeasures: Soil Liming and Exhaust Purification. U.S. EPA Translation TR-820011; EPA/NCSU Acid Deposition Program; North Carolina State University, Raleigh.

Van Breemen, N., Burrough, P. A., Velthorst, E. J., Van Dobben, H. F., De Wit, T., Ridder, T. B., \& Reijnders, H. F. R. (1982). Soil acidification from atmospheric ammonium sulphate in forest canopy throughfall. Nature, 299(5883), 548-550.

Wykoff, W. R., Crookston, N. L., \& Stage, A. R. (1982). User's Guide to the Stand Prognosis Model. Forest Service, Department of Agriculture, United States General Technical Report INT-133, 118. 
Yaussy, D. A. (2000). Comparison of an empirical forest growth and yield simulator and a forest gap simulator using actual 30-year growth from two even-aged forests in Kentucky. Forest Ecology and Management, 126(3), 385-398. 
Appendix A: Base model performance vs actual growth of calibration stands

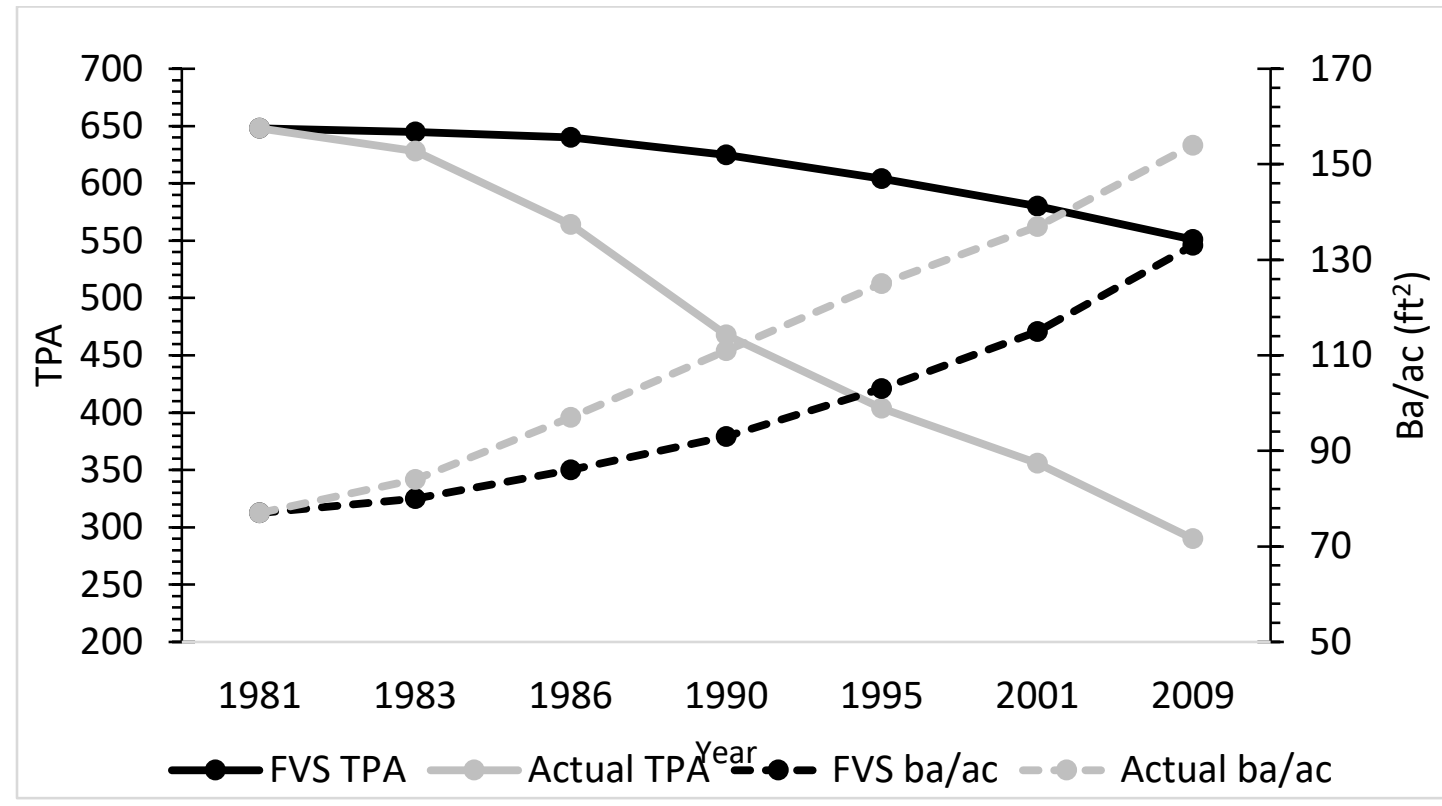

Figure 1. Base FVS Model Performance plotted against actual growth data for calibration Stand 33.

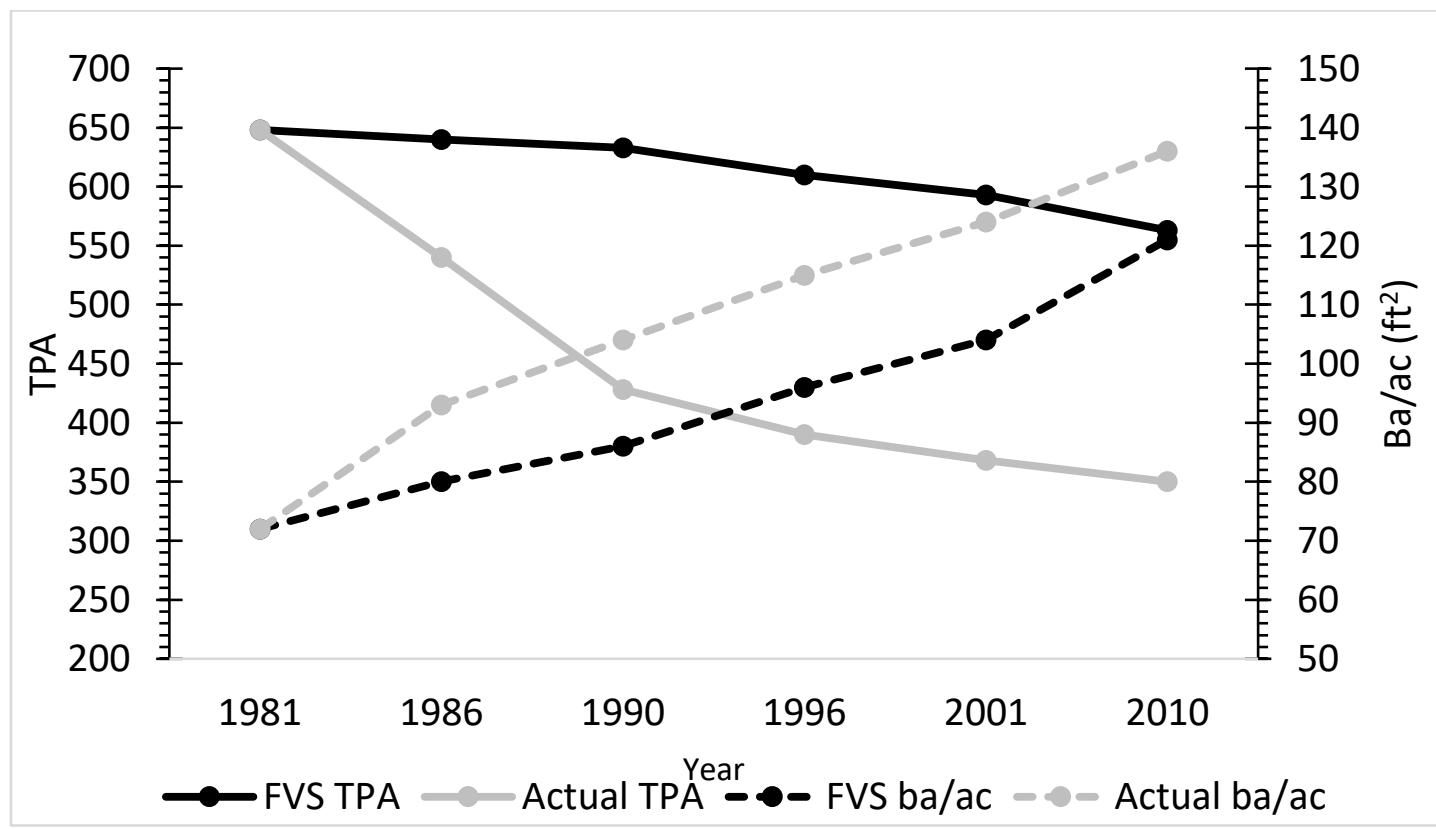

Figure 2. Base FVS Model Performance plotted against actual growth data for calibration Stand 34. 


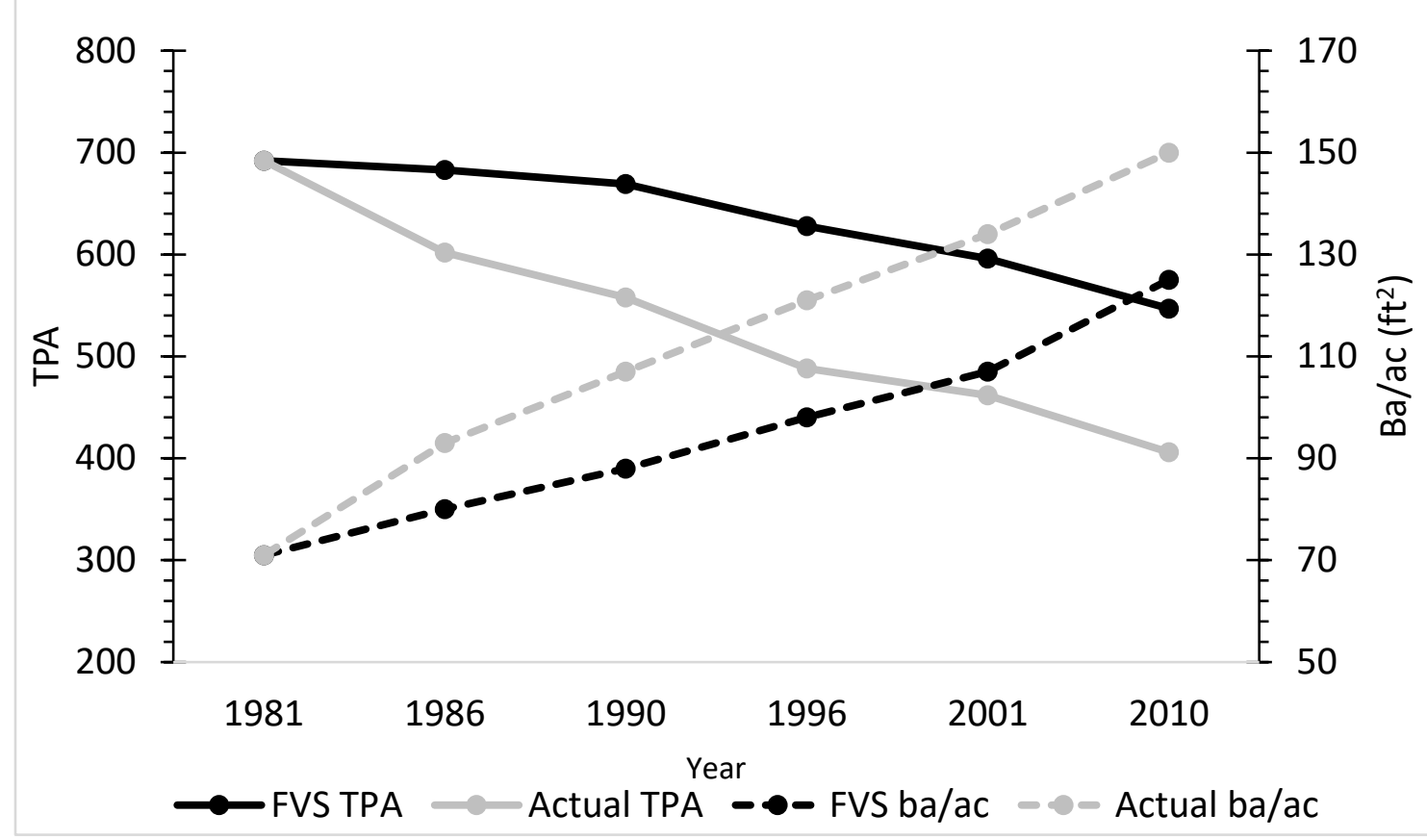

Figure 3. Base FVS Model Performance plotted against actual growth data for calibration Stand 35 .

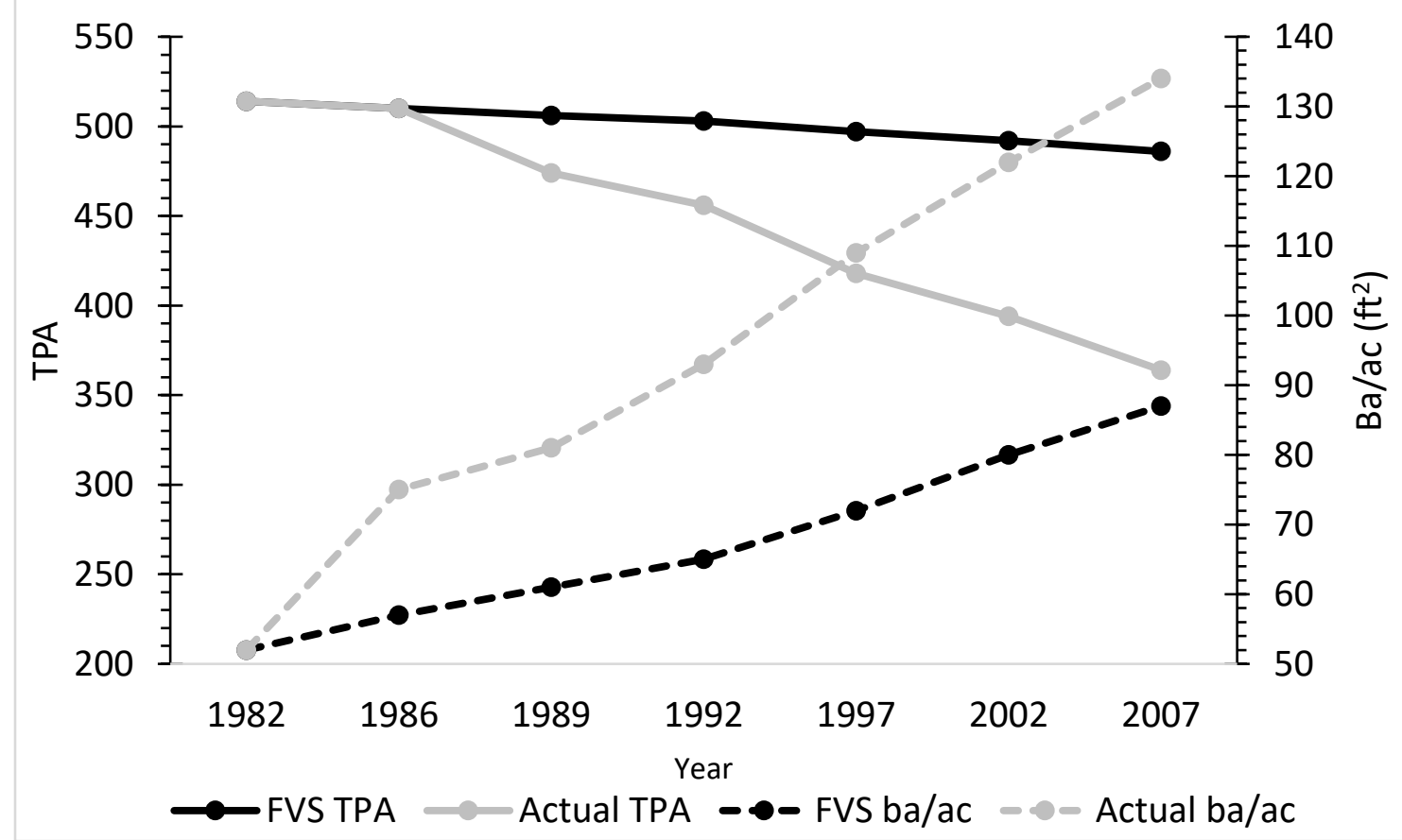

Figure 4. Base FVS Model Performance plotted against actual growth data for calibration Stand 36. 


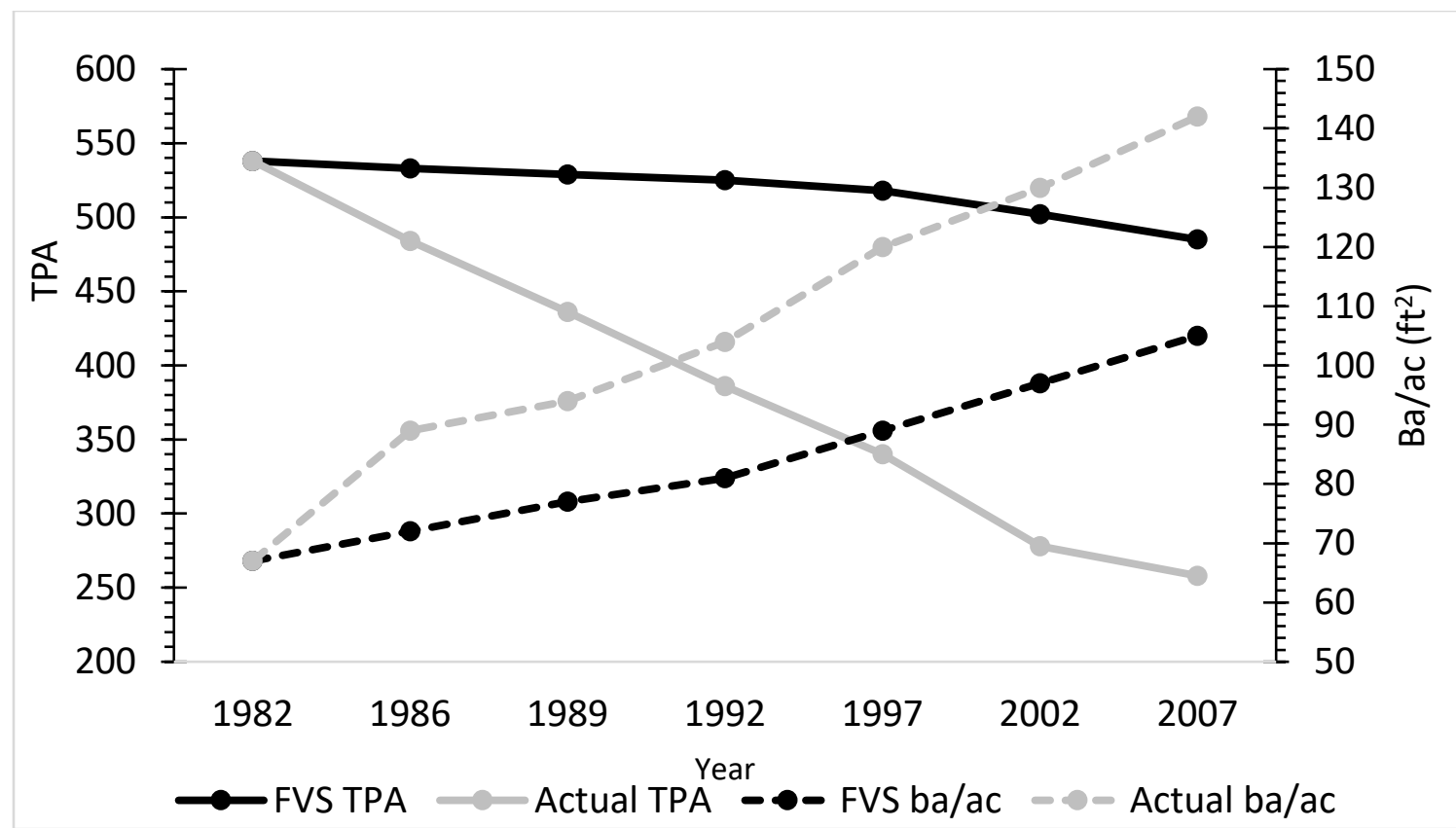

Figure 5. Base FVS Model Performance plotted against actual growth data for calibration Stand 37.

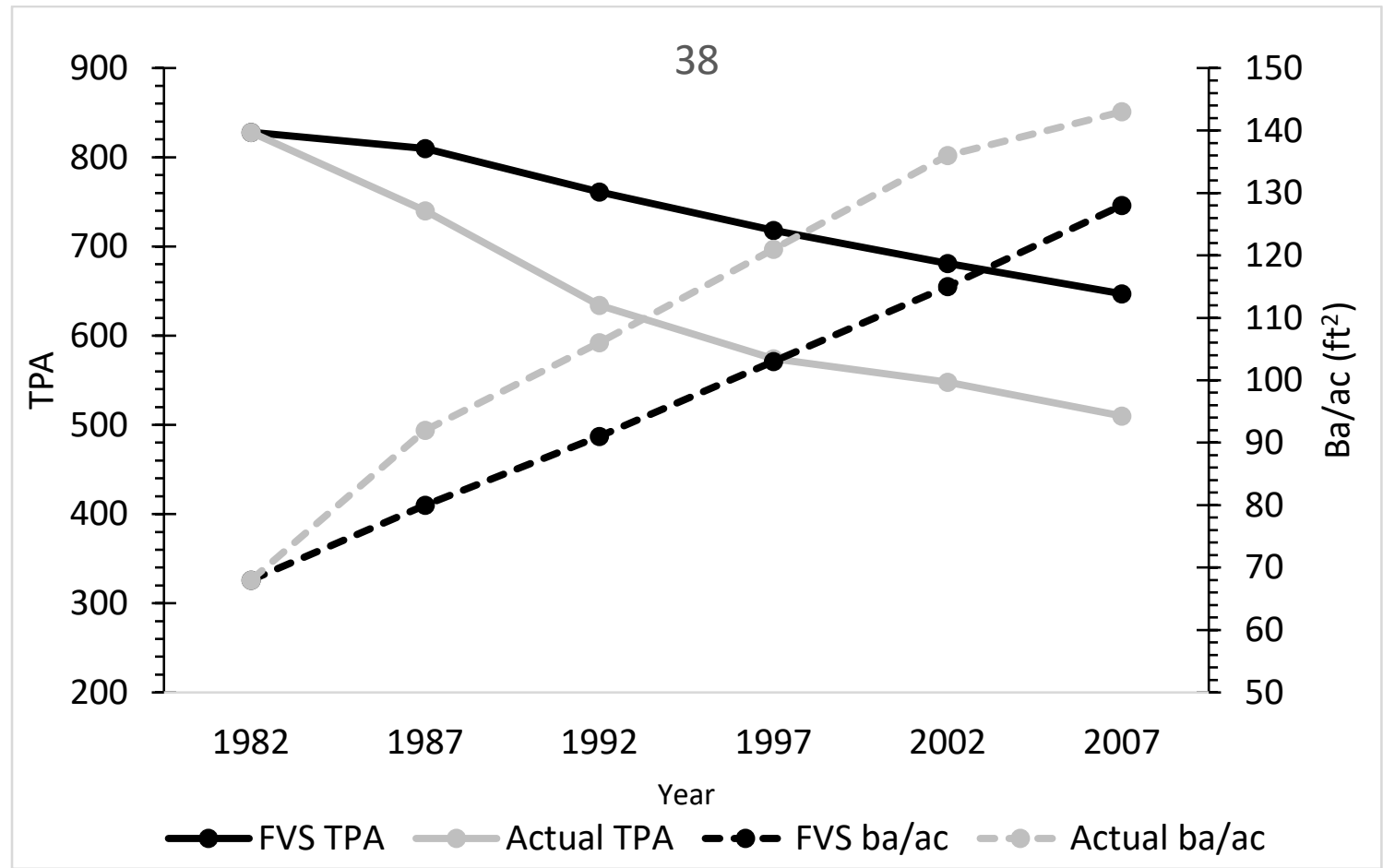

Figure 6. Base FVS Model Performance plotted against actual growth data for calibration Stand 38. 


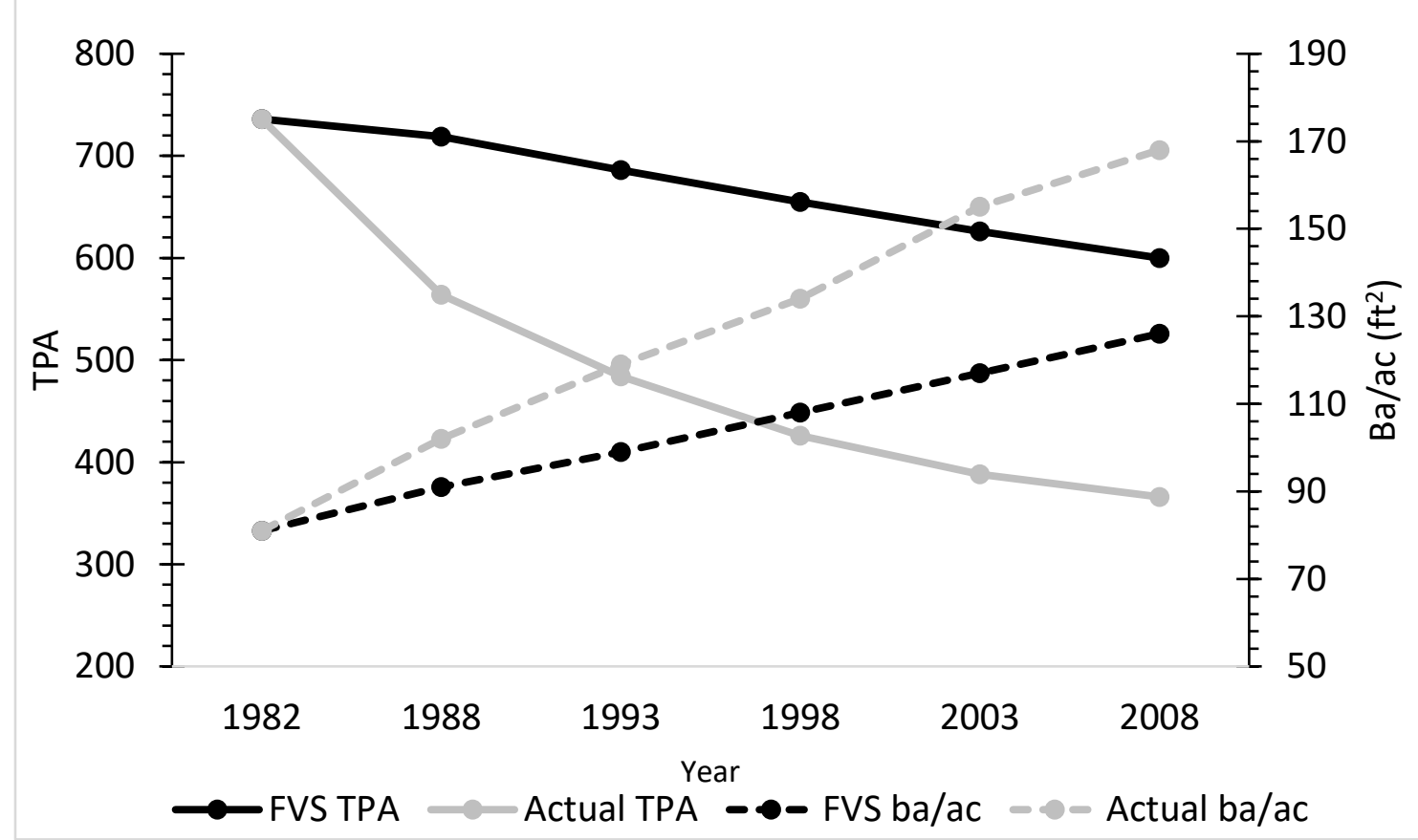

Figure 7. Base FVS Model Performance plotted against actual growth data for calibration Stand 39.

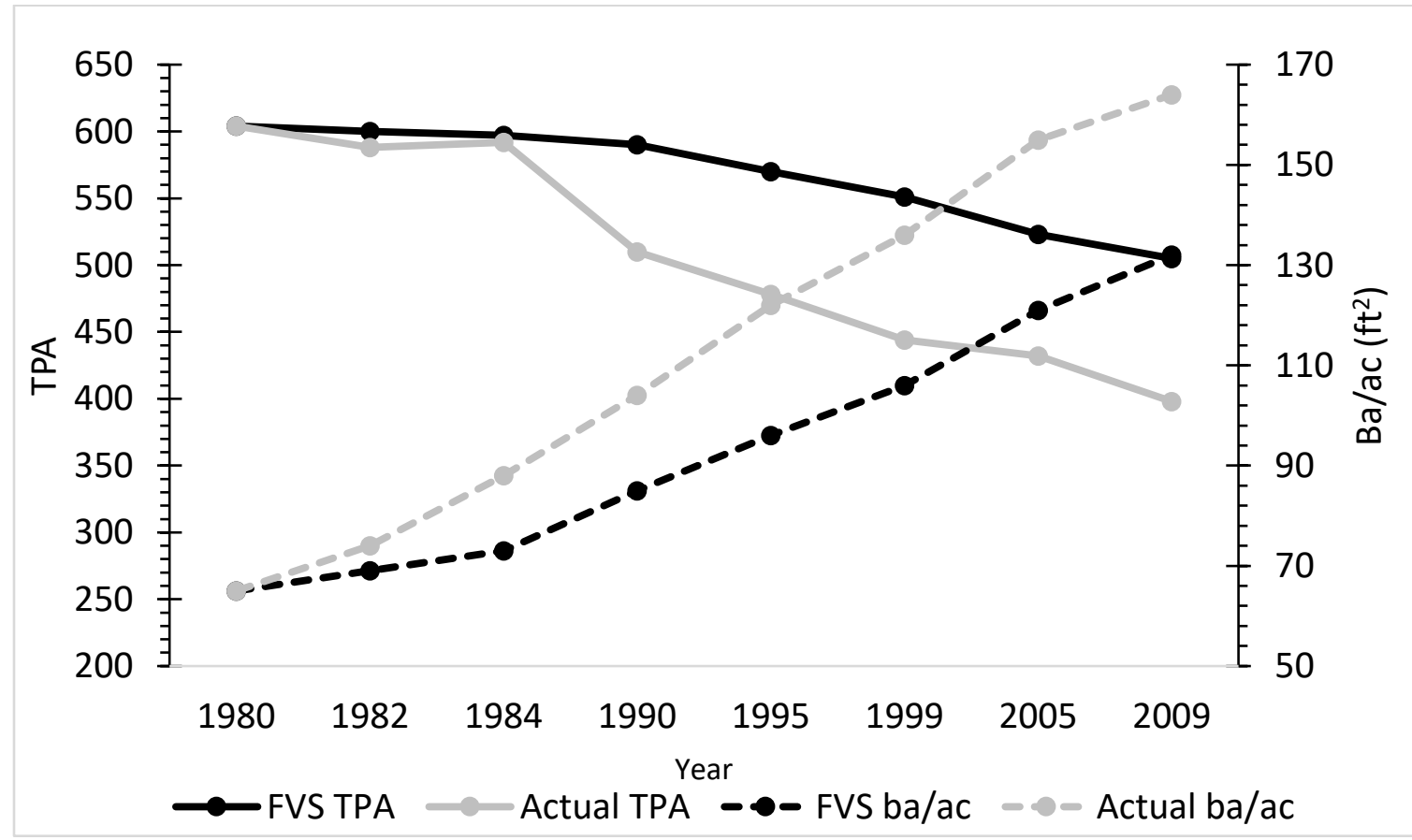

Figure 8. Base FVS Model Performance plotted against actual growth data for calibration Stand 43. 
Appendix B: Calibrated Model performance vs. actual growth of calibration stands

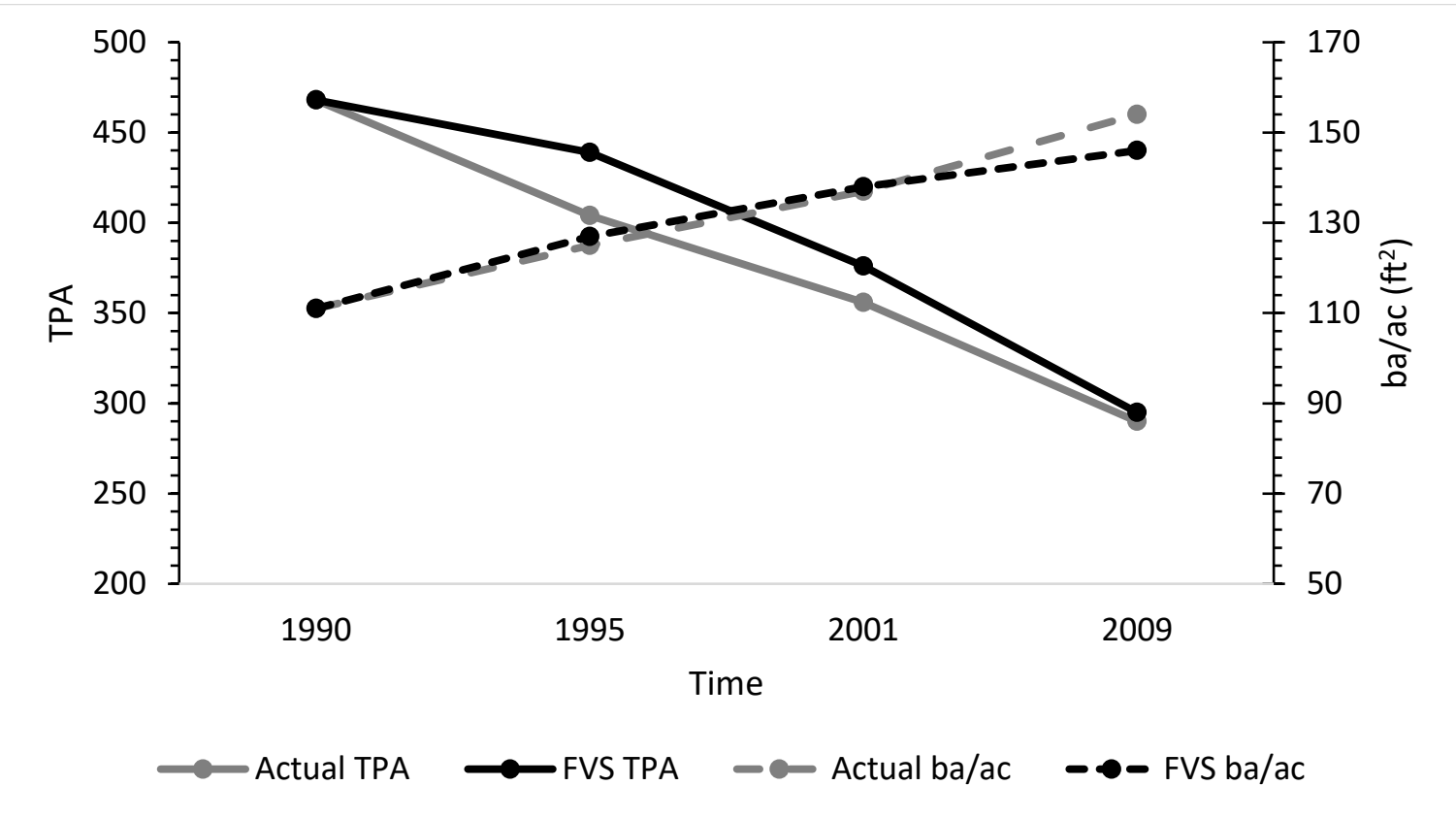

Figure 1. Locally Calibrated FVS Model performance plotted against actual growth data for calibration Stand 33.

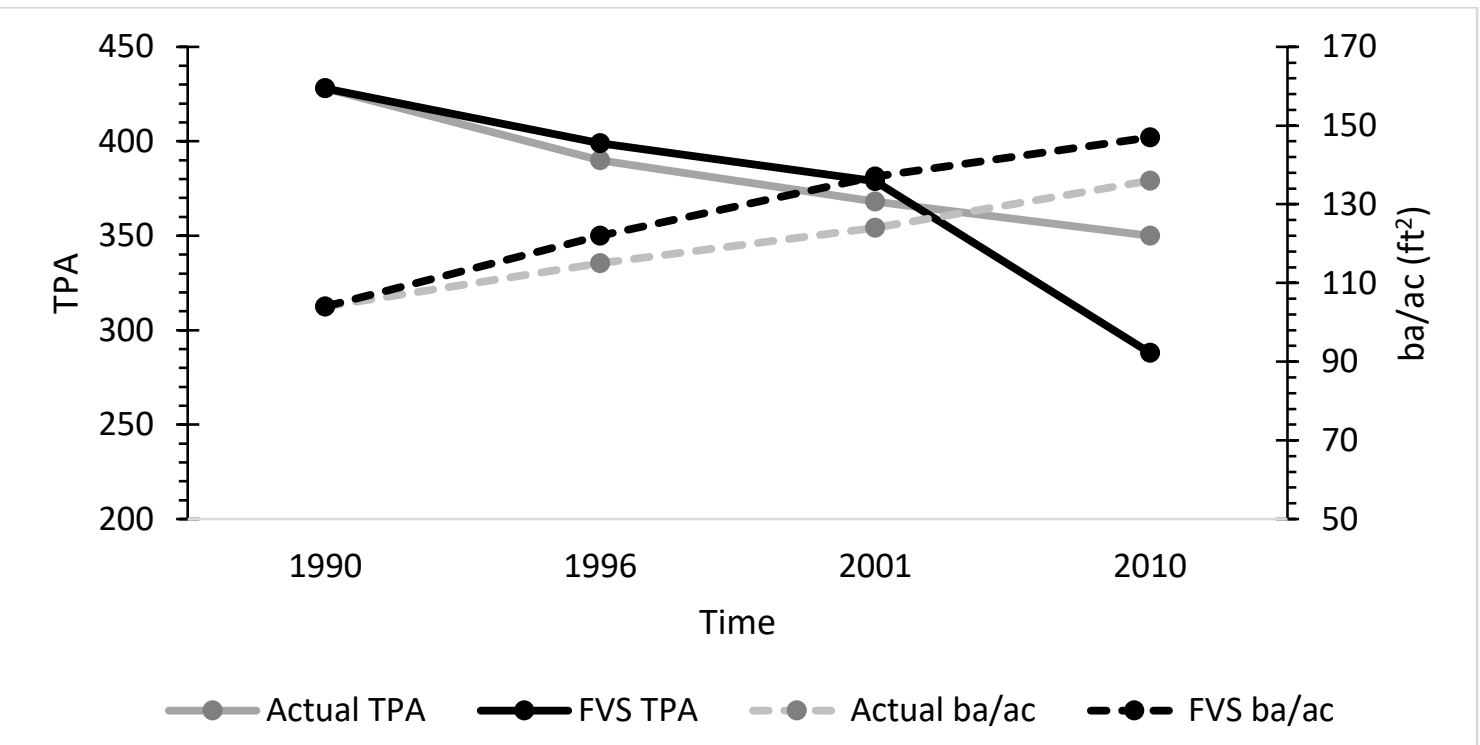

Figure 2. Locally Calibrated FVS Model performance plotted against actual growth data for calibration Stand 34. 


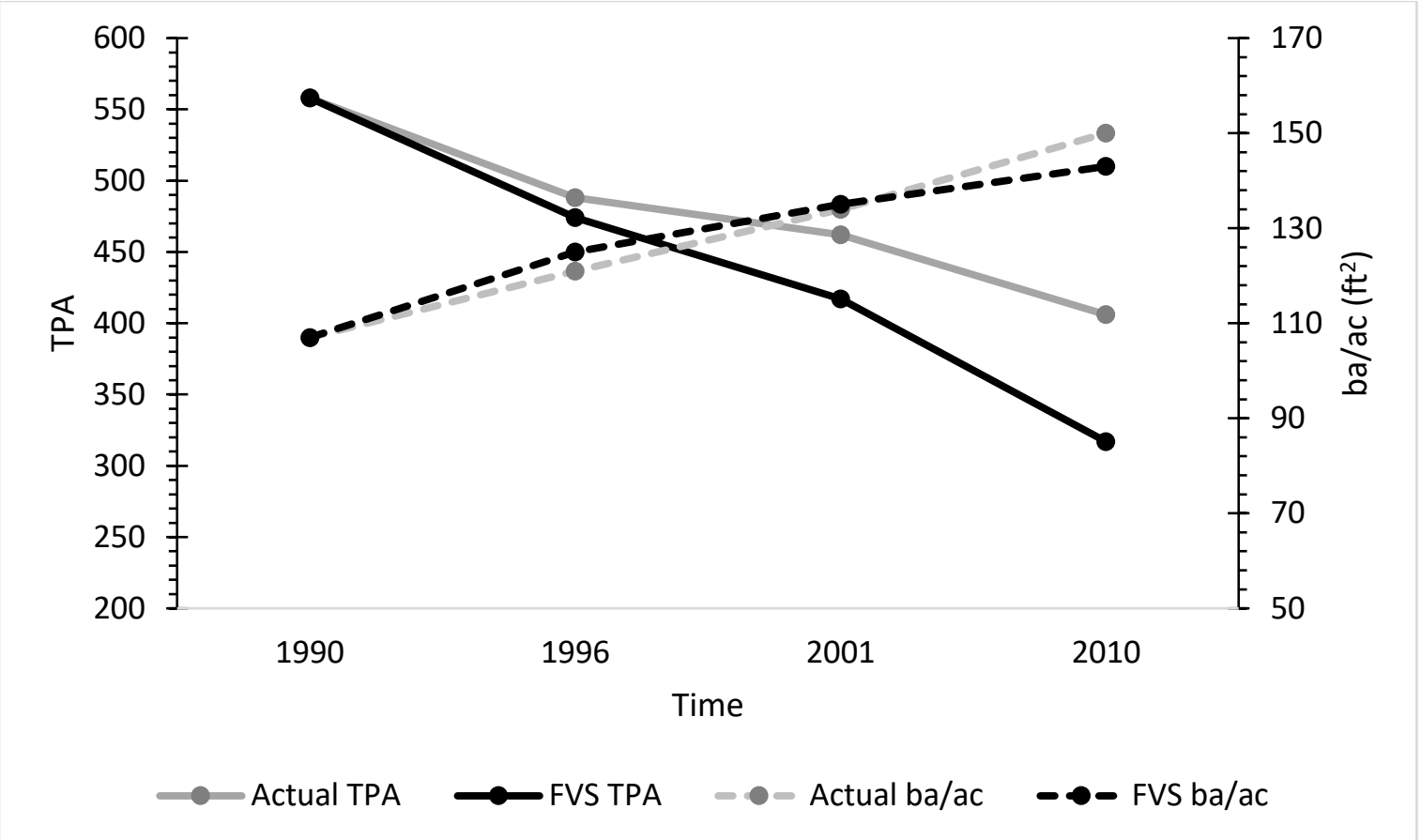

Figure 3. Locally Calibrated FVS Model performance plotted against actual growth data for calibration Stand 35.

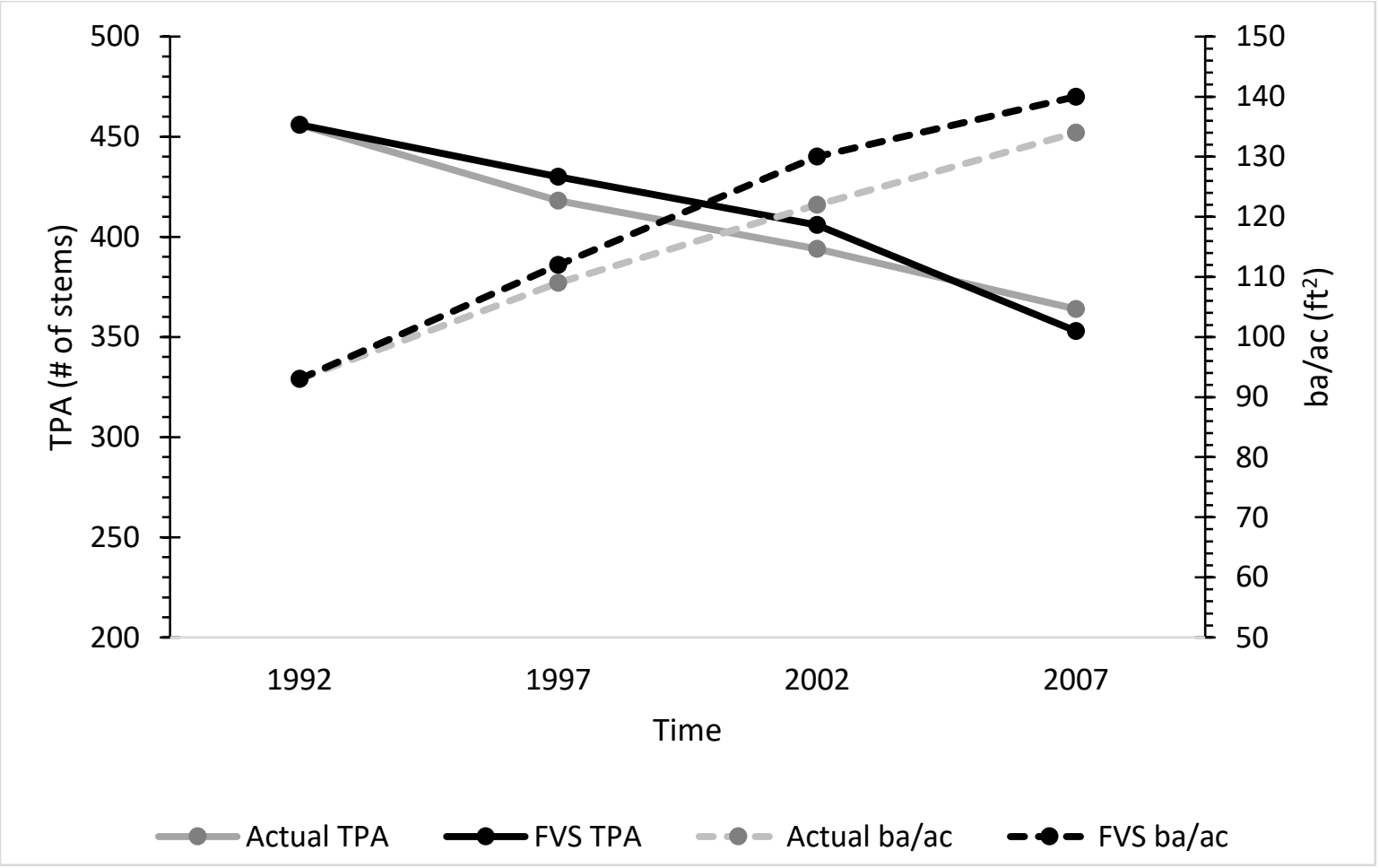

Figure 4. Locally Calibrated FVS Model performance plotted against actual growth data for calibration Stand 36. 


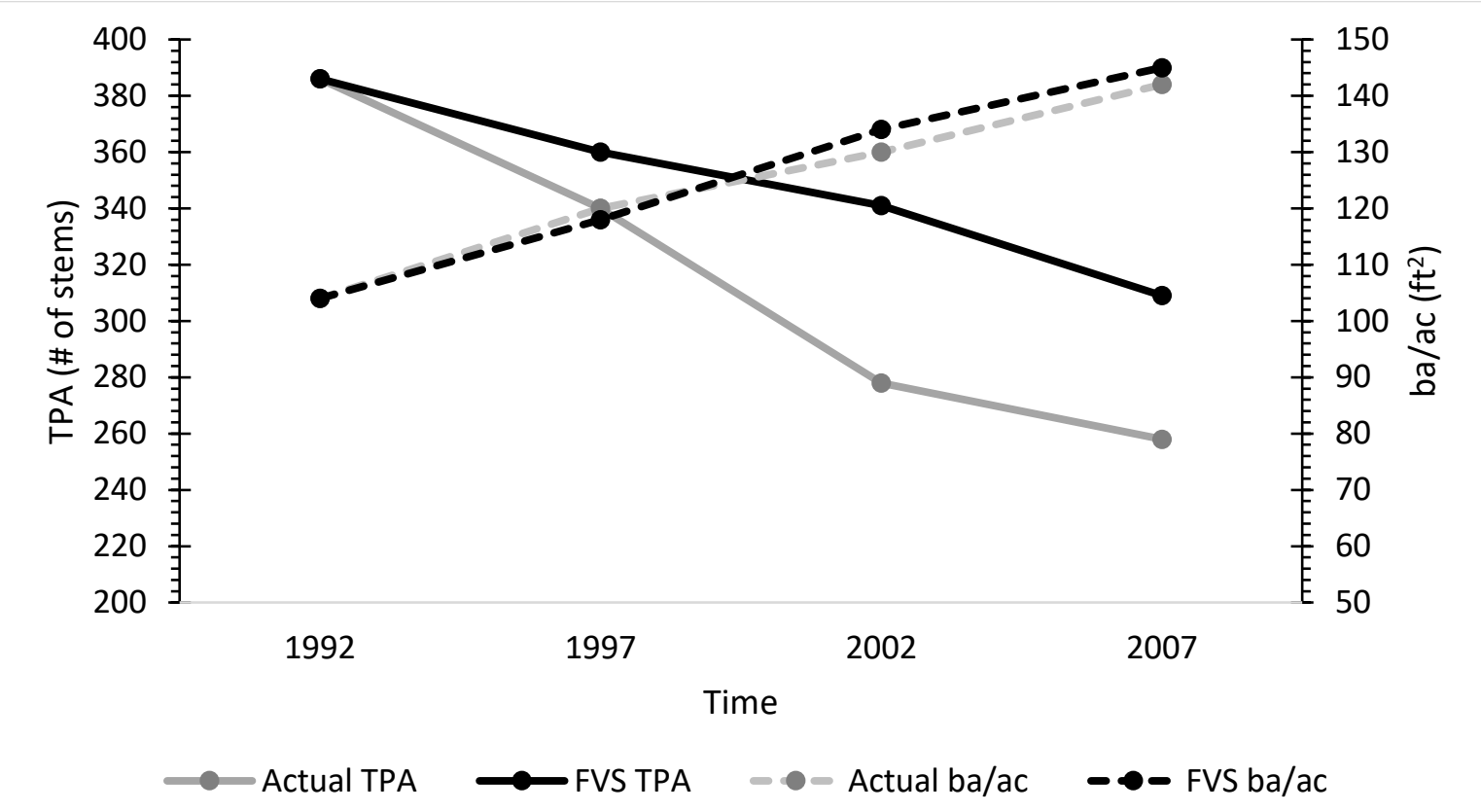

Figure 5. Locally Calibrated FVS Model performance plotted against actual growth data for calibration Stand 37.

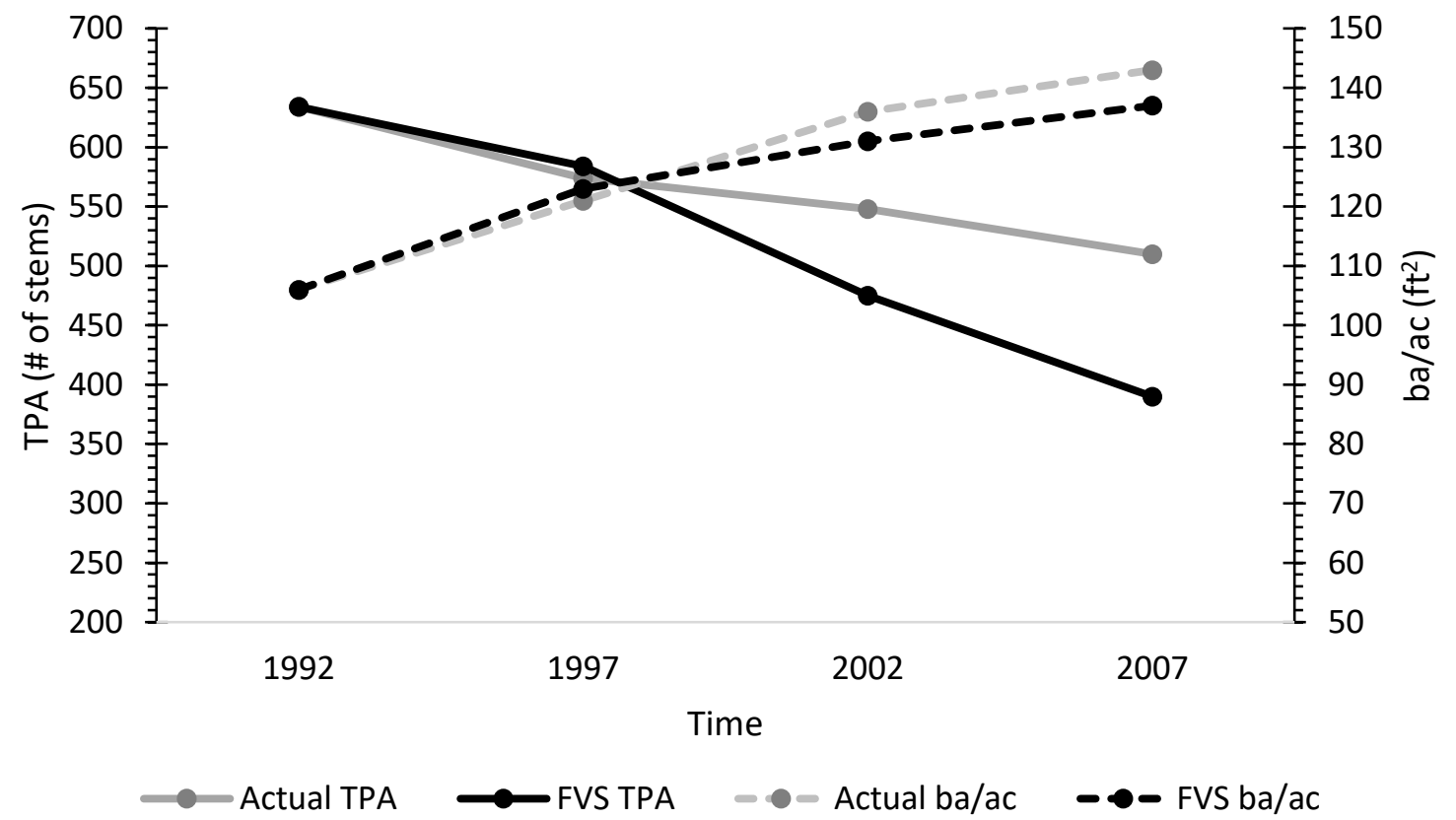

Figure 6. Locally Calibrated FVS Model performance plotted against actual growth data for calibration Stand 38. 


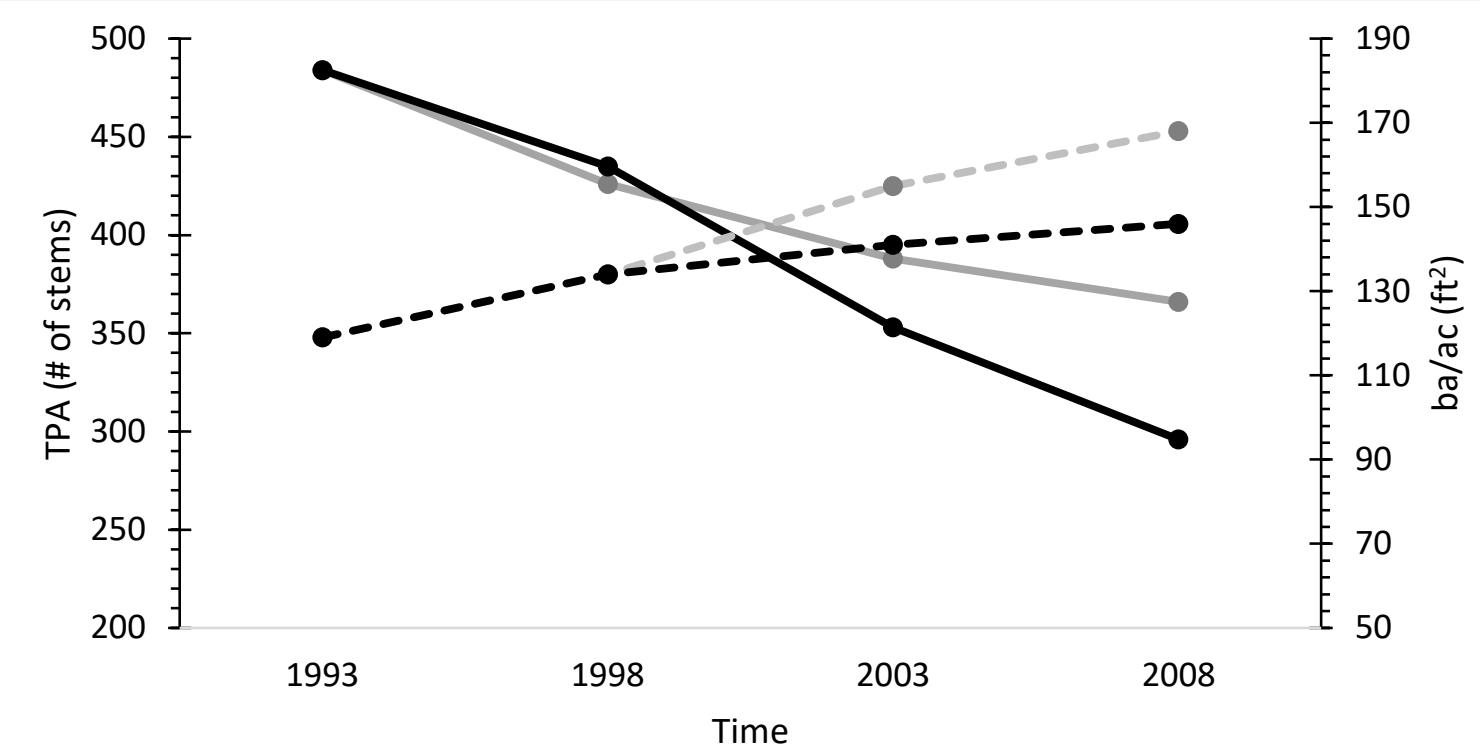

$\longrightarrow$ Actual TPA $\longrightarrow$ FVS TPA $\rightarrow-$ Actual ba/ac $\quad \leadsto-$ FVS ba/ac

Figure 7. Locally Calibrated FVS Model performance plotted against actual growth data for calibration Stand 39.

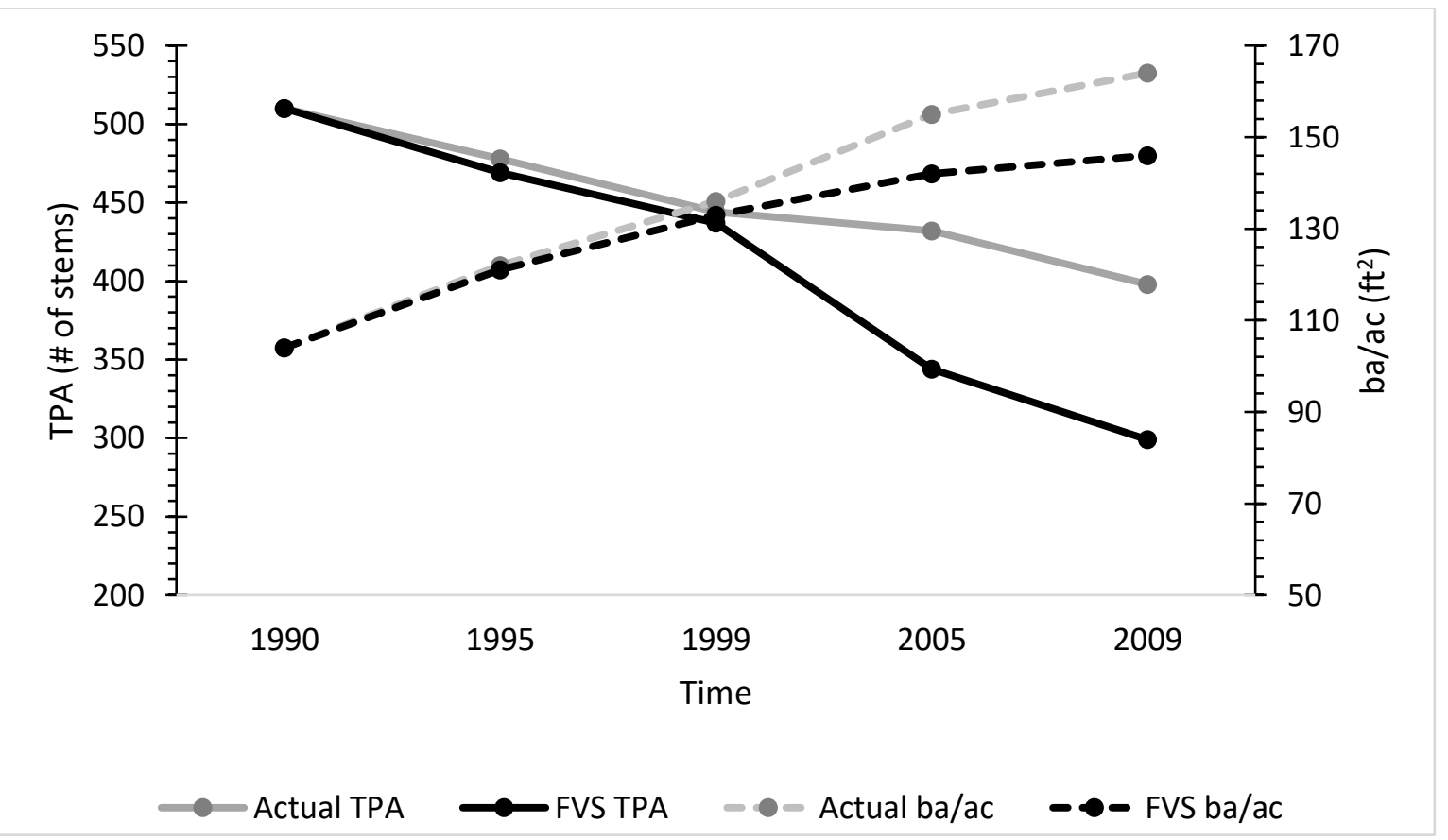

Figure 8. Locally Calibrated FVS Model performance plotted against actual growth data for calibration Stand 43. 
Chapter 4: General Conclusions on the Long-Term Effects of Chronic Additions of Nitrogen, Sulfur and Lime to a Central Appalachian Forest. 
By utilizing past and present data from permanent growth plots in the Fernow Experimental Forest I was able to: 1) the stand level species-specific responses to 21 years of ammonium sulfate and lime additions to an aggrading central Appalachian forest; 2) describe the trend in aboveground treatment response of the FM LTSP trees over the past 10 years, and 3) locally calibrate and validate a forest growth model to project species specific responses in volume production to the LTSP treatments over the next 40 years.

With respect to the current response of the overstory trees on the FM LTSP site, I found that chronic additions of ammonium sulfate and lime have not affected the accumulation of biomass on the site at any point in the last 10 years. Although pin cherry (Prunus pensylvanica) is still the species of highest relative importance value on site $(\approx 29 \%)$, the species has decreased in relative importance by $23 \%$ in the past 8 years, and likely has begun the rapid decline that is associated with its short life cycle. Ambient levels of $\mathrm{N}$ deposition, as well as experimental additions have led to a decrease in species richness, likely discouraging growth of sensitive species such as sugar maple (Acer saccharum). The use of dolomitic lime to mitigate the negative effects of elevated $\mathrm{N}$ deposition may allow the species to persist in areas vulnerable to base cation depletion.

Although there were no significant species specific responses to the treatments at age 21, current trends in number of trees in the treatment areas are predicted to lead to future changes in species composition of the mature stand. Current trends of yellow-poplar (Liriodendron tulipifera) trees per acre show the species responding negatively to added N. This initial difference is projected to result in a decrease in yellow poplar productivity on the WT+NS and 
LIME plots, allowing added growing space for species such as red maple (Acer rubrum) black cherry (Prunus serotina), and cucumbertree (Magnolia acuminata). Fewer, and smaller numbers of sweet birch (Betula lenta) stems in the LIME plots currently, are expected to result in the species making up a very small portion of the stand after the 40 year projection period.

The long-term negative effects of elevated rates of nitrogen and sulfur deposition may not be noticeable at the stand level. Central Appalachian forest are highly productive, and certain species seem to be more tolerant of base cation depletion than others. Forest managers need to be observant of changes in species composition and individual species productivity in areas that receive high levels of atmospheric deposition of $\mathrm{N}$. The use of dolomitic lime may be useful in preventing sensitive species from being excluded from areas of base cation depletion. However, chronic additions of lime may also negatively affect the growth of other commercially important species such as yellow-poplar and sweet birch.

Results from this study continue to build upon the knowledge of the complex response of forests to chronic additions of $\mathrm{N}$ and $\mathrm{S}$. I also hope that the framework provided for calibration of the northeast variant of FVS will stimulate the interest of forest managers in using the program in the central Appalachian region. The study also highlights the value of continuation of measurements of long-term studies and growth plots. This project would not have been possible without the foresight of past investigators to implement, monitor and record the response of vegetation to anthropogenic influences. 